\title{
Immunometabolism: new insights and lessons from antigen-directed cellular immune responses
}

\author{
Renata Ramalho ${ }^{1} \cdot$ Martin Rao ${ }^{2} \cdot$ Chao Zhang $^{3} \cdot$ Chiara Agrati $^{4} \cdot$ Giuseppe Ippolito $^{4} \cdot$ Fu-Sheng Wang $^{3}$. \\ Alimuddin Zumla ${ }^{5}$. Markus Maeurer ${ }^{2,6}$
}

Received: 22 January 2020 / Accepted: 2 April 2020/Published online: 9 June 2020

(C) Springer-Verlag GmbH Germany, part of Springer Nature 2020

\begin{abstract}
Modulation of immune responses by nutrients is an important area of study in cellular biology and clinical sciences in the context of cancer therapies and anti-pathogen-directed immune responses in health and disease. We review metabolic pathways that influence immune cell function and cellular persistence in chronic infections. We also highlight the role of nutrients in altering the tissue microenvironment with lessons from the tumor microenvironment that shapes the quality and quantity of cellular immune responses. Multiple layers of biological networks, including the nature of nutritional supplements, the genetic background, previous exposures, and gut microbiota status have impact on cellular performance and immune competence against molecularly defined targets. We discuss how immune metabolism determines the differentiation pathway of antigen-specific immune cells and how these insights can be explored to devise better strategies to strengthen anti-pathogen-directed immune responses, while curbing unwanted, non-productive inflammation.
\end{abstract}

Keywords Infection $\cdot$ Cancer $\cdot$ Immunometabolism $\cdot$ Immunotherapy $\cdot$ Inflammation $\cdot$ Microbiome $\cdot$ Tuberculosis $\cdot$ MTB $\cdot \mathrm{T}$ cell $\cdot$ Innate immune cell $\cdot$ Cytokine $\cdot$ Nutrition $\cdot$ Mitochondria

This article is a contribution to the special issue on: Immunopathology of unresolved tropical diseases - Guest Editor: Marcel Tanner

Markus Maeurer

markus.maeurer@fundacaochampalimaud.pt

1 Centro de Investigação Interdisciplinar Egas Moniz (CiiEM, U4585 FCT), Applied Nutrition Studies Group G.E.N.A.-IUEM), Instituto Universitário Egas Moniz, Egas Moniz Higher Education School, Monte de Caparica, Portugal

2 ImmunoSurgery Unit, Champalimaud Centre for the Unknown, Lisbon, Portugal

3 Treatment and Research Center for Infectious Diseases, The Fifth Medical Center of PLA General Hospital, National Clinical Research Center for Infectious Diseases, Beijing, China

4 INMI L. Spallanzani, Rome, Italy

5 Division of Infection and Immunity, University College London and NIHR Biomedical Research Centre, UCL Hospitals NHS

Foundation Trust, London, UK

6 I Medizinische Klinik, Johannes Gutenberg University Mainz, Mainz, Germany

\section{Introduction}

Clinical immunologists have (re)discovered that the profile of cellular metabolism shapes the outcome of cellular development and immune functions: immunometabolism [1-3]. This prompted cross-fertilizing preclinical and clinical research between immunology, nutrition, and biochemistry [4]. The field of immunometabolism is marked by the impact of metabolic reprograming on the immune response as well as studying the fate of immune cells $[5,6]$. The immunometabolic profile of cells influences their activation, their proliferative capacity, their quiescent state in tissues and in the systemic circulation. The functional specificity of each immune cell subset determines its biochemical requirements which is associated with different metabolic phenotypes $[2,7,8]$. These phenotypes are linked with variations in nutrient and oxygen availability, $\mathrm{pH}$, as well as fluctuations during immune cell trafficking [2]. Thus, a well-founded understanding of molecular interactions between nutrient availability, biochemical requirements, and cellular metabolism is crucial to recognize how these components jointly affect immunodynamics in pathological conditions and ultimately shape the host immune response $[9,10]$. We review therefore here more recent insights in 
immunometabolism in infections and cancer - a timely exercise since (i) nutrients are often limited in resourceconstrained countries, (ii) immunonutritional concepts are often not considered in vaccine or adjuvant treatment protocols in patients with infections, (iii) similar molecular pathways are functional in "chronic antigen stimulation" in patients with bacterial and viral infections or cancer. Insights from curbing immunopathology and eliciting protective immune responses in patients with cancer will therefore cross-fertilize the advancement of new treatment concepts of patients with infectious diseases — particularly where nutrients are limited. We would also like to point out that such a review provides the platform of discussing individual mechanistic concepts. However, although a more individual approach in patient management is scientifically sound, the clinical reality is often different: individuals have a different genetic background, they have been exposed to different pathogens/commensals and may suffer from different infections - at the same time or in different orders that may shape the quality and quantity of immune responses. A more recent, prominent example [11] is the acquired capacity of the organism - in early life - to differentiate between commensal bacterial that colonize the skin versus potential pathogenic bacterial species, where antigen-specific regulatory T-cells (Tregs), tolerance mechanisms, and the IL-1-receptor-IL-1 $\beta$ axis play a prominent role. It is obvious that age, the country, nature of exposure to commensals and potential pathogens plays a pivotal role. The need to integrate these variations in different networks - and to extract biologically and clinically relevant concepts - is appreciated and fueled the discussion to obtain better models that integrate anatomical and biological diversity [12].

The study of metabolism has revealed six core biochemical pathways which impact on immune cell reprograming: glycolysis, tricarboxylic acid (TCA) cycle, fatty acid oxidation (FAO), fatty acid synthesis (FAS), pentose phosphate pathway (PPP), and amino acid synthesis (AAS) [13, 14]. Additional pathways have been described as modulators of the complexity of the immune response, mainly those leading to the biosynthesis of polyamines, cholesterol, hexosamines, and nucleotides [15]. The biochemical demands of each immune cell type are intrinsically liked to its function, especially those related to quiescence/memory and activation/ proliferation $[14,16]$. That said, different immune cell functions are, in fact, associated with distinct metabolic configurations: resting immune cells utilize energetically efficient processes such as the tricarboxylic acid (TCA), linked to the generation of ATP via oxidative phosphorylation (OXPHOS), whereas activated cells prefer glycolysis to generate adequate levels of energy storage to support survival and produce numerous biosynthetic intermediates to allow for cellular growth and proliferation [14]. $\mathrm{CD}^{+} \mathrm{T}$-cells are believed to be dependent on FAO in regard to immune effector functions and tissue homing, yet more recent evidence suggests that memory $\mathrm{T}$ - cells may use alternate pathways for these immune effector functions [17-22]. This plasticity of immune cells modulates metabolic reprogramming from an inflammatory to antiinflammatory or immunomodulatory phenotype or vice versa $[7,8,23]$, which is of special interest for exploitation as an anti-tumor immune-based strategy [24]. In fact, cancer cells behave more like activated immune cells with increased biochemical demands and rely on glycolysis for survival [25-27].

Nutrients play a pivotal role in the context of immune cell metabolic phenotypes, further supported (and influenced) by gut microbiota and gastrointestinal organs such as the pancreas, colon, and liver [28, 29]. Immunonutrition is a growing biomedical discipline [30] that aims to affect immune cell functions directly by delivering signaling metabolites by regulating nutrient availability [31]. Figure 1 summarizes different metabolic pathways and biological cell functions.

\section{Integration of metabolism and immunity}

\section{Cellular metabolism of immune cells}

As stated earlier, the main metabolic pathways involved in immune cell survival, proliferation, and activation are glycolysis, TCA cycle, PPP, FAO, FAS, and AAS (particularly those of glutamine, arginine, and tryptophan). Glycolysis occurs in the cytosol and generates two ATP molecules by substrate-level phosphorylation and pyruvate that enter mitochondria and are converted to acetyl-coenzyme A (acetyl CoA). Glycolysis is a relatively inefficient pathway for the generation of cellular ATP but is involved in several processes due to its capacity of being rapidly activated via the induction of key enzymes such as pyruvate kinase, glyceraldehyde 3 phosphate dehydrogenase, aldolase, and enolase [32, 33]. Cells requiring rapid production of ATP will switch to glycolysis as increased cell growth kinetics demand an equally (if not higher) turnover of biosynthetic intermediates [13, 34-36]. For example, glycolysis inhibition by modulation of pyruvate kinase M2 induces the polarization of macrophages towards an alternatively activated phenotype (M2 macrophages) in terms of gene expression, in addition to boosting IL-10 production [32, 37, 38]. It has been recognized that activating cell signals such as cytokines may lead to the generation of ATP, which will support the TCA cycle in providing intermediates for PPP, glycosylation reactions, and the biosynthesis of key biomass constituents like serine, glycine, alanine, and acetyl-CoA $[13,33]$. This is true for macrophages (phagocytosis, inflammatory cytokine production) [39, 40], dendritic cells (Ag presentation) [41], as well as T-cells (effector cytokines, IL-17 for Th17) [42].

PPP is a metabolic pathway parallel to glycolysis. It generates NADPH, pentoses, and ribose 5-phosphate [43]. This pathway involves oxidation of glucose but is an anabolic 


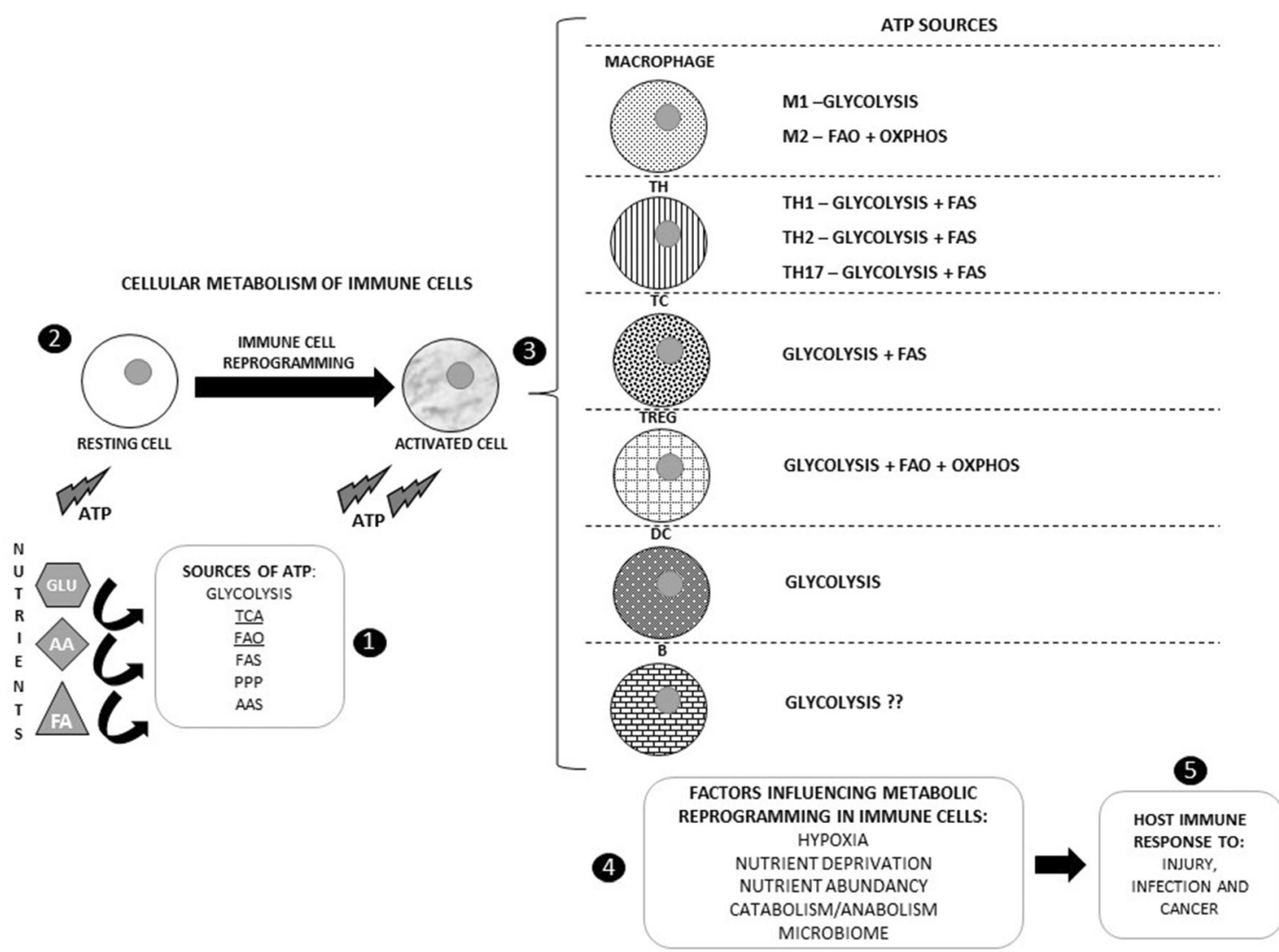

Fig. 1 Cellular metabolism of immune cells and factors influencing metabolic reprogramming. (1) Six core metabolic pathways are involved in fueling cells for biological functions and differentiation, generating ATP from nutrients. (2) Resting immune cells usually rely on TCA and FAO for obtaining ATP and require immune reprogramming for activation. (3) Activated immune cells use different metabolic pathways to obtain ATP for proliferation. (4) Some external

pathway rather than a catabolic one [43]. NADPH is generated during the oxidative phase, whereas pentoses are produced during the non-oxidative phase of PPP. NADPH will, therefore, be used to generate ROS during respiratory burst and as a counterbalance to generate glutathione and other antioxidants. This is used by macrophages differently according to their phenotype $[44,45]$.

The TCA cycle (also known as the citric acid cycle or Krebs cycle) is a metabolic pathway for generating ATP and carbon dioxide through the oxidation of acetyl-CoA derived from carbohydrates, fats, and proteins [46]. Additionally, the TCA cycle also provides NADH to be used in diverse biochemical reactions while TCA cycle-derived citrate, uridine diphosphate $\mathrm{N}$-acetylglucosamine (UDP-GlcNAc), itaconic acid, and succinate are important for immune cell physiology [46]. The TCA cycle operates both in normoxia and hypoxia $[33,38]$.

Fatty acid (FA) metabolism consists of both (energygenerating) catabolic and anabolic processes necessary for the synthesis of important biological building blocks such as triglycerides, phospholipids, secondary messengers factors condition metabolic reprogramming of immune cells, such as hypoxia, nutrient deprivation and abundancy, catabolism, anabolism, and the microbiome. (5) These factors influence quality and quantity of immune reactivity in infection(s) and cancer. GLU, glucose; AA, amino acids; FA, fatty acids; TCA, tricarboxylic acid cycle; FAO, fatty acid oxidation; FAS, fatty acid synthesis; PPP, pentose phosphate pathway; AAS, amino acid synthesis

(arachidonic acid and free fatty acids), hormones, and ketone bodies. When compared to other macronutrient classes, FAs generate the most ATP on an energy per gram basis when completely oxidized to $\mathrm{CO}_{2}$ and water by beta oxidation and the TCA cycle. Many immune cells that are not inflammatory in nature and exhibit increased cellular lifespans (M2 macrophages, regulatory T-cells (Treg), memory $\mathrm{CD}^{+} \mathrm{T}$-cells) have been demonstrated to rely on FAO, as previously mentioned [20, 47, 48]. Nevertheless, FAS seems to positively regulate the generation and function of pro-inflammatory innate and adaptive immune cells [49]. The efficacy of lipid oxidation for energy generation and the necessity of lipid synthesis for biosynthesis and cell growth suggest that proinflammatory and regulatory immune cells show fundamental differences in their reliance on ATP generation for growth [20].

Glutamine, arginine, and tryptophan are the most wellstudied amino acids affecting the immune system. Insufficient supply of glutamine has been related to increased mobilization from muscles and low plasma levels [50, 51]. Human studies have demonstrated that these low plasma 
levels of glutamine are related to reduced B-cell differentiation [52], decreased IL-2 production (and IL-2R expression), downregulation of HLA class II expression on and reduced antigen presentation by macrophages [51, 53]. Glutamine can be used by macrophages for NADPH production [53]. Murine macrophages and neutrophils involved in pinocytosis have, in fact, been shown to prefer/require NADPH supplied by glutamine metabolism rather than PPP, since glucose supplied by the latter pathway is used for fat storage [54]. In murine Tcells, glutamine is used as a resource in nucleic acid synthesis and as an energy source [55]. Pertaining to arginine metabolism and immune cells, arginase-1 is responsible for the breakdown of arginine to ornithine and plays a role in the immune function regulation of activated T-cells through depletion of arginine in the local microenvironment (as controlling arginine bioavailability leads to control of nitric oxide production), which has been described in experimental models of cancer and tuberculosis [56-58]. Arginine depletion has been related to T-cell suppression, mainly by reduced expression of the $\mathrm{CD} 3-\zeta$ chain (and concomitant lower expression of the TCR complex) as well as downregulation and subdued enzymatic activity of the cyclin D3/CDK4 complex which is known to regulate cell cycle progression $[59,60]$. Interestingly, elevated levels of arginase-1 have been found in the splenocytes of tumor-bearing mice [61]. Moreover, cancer and postoperative patients present with a lack of the CD3- $\zeta$ chain, dysfunction and reduced number of T-cells, and increased arginase-1 activity [62-64]. Idoleamine-2,3 dioxygenase (IDO), which oxidatively degrades tryptophan in the kynurenine pathway, has been considered a key enzyme in host immune function [65]. The properties exhibited by some innate immune cells, i.e., human $\mathrm{CD} 123^{+}$DC subset $\left(\mathrm{CD} 11 \mathrm{c}^{+} \mathrm{CD} 8 \alpha^{+} \mathrm{DC}\right.$ subset in mice) and macrophages to induce IDO, have been demonstrated to be responsible for the modulation of not only T-cell function mainly via tryptophan depletion but also IDO-cytotoxic metabolites [65-67], although the latter mechanism requires further elucidation.

Aerobic glycolysis appears to be a characteristic feature of many rapidly dividing cells, including cancer and immune cells, even when sufficient oxygen is present to support OXPHOS $[8,35]$. In proliferating cells, the increase in lactate production may result from the contribution of growth factormediated increases in glucose uptake, increased ATP consumption associated with cell growth, and low NAD+/ NADH ratio secondary to oxidative biosynthesis [68-70]. The advantage of this metabolic phenotype in proliferating cells is to help meeting the biochemical requirements of biosynthesis and allow differentiation [71]. Aerobic respiration produces a larger fraction of cellular ATP from mitochondrial OXPHOS, while glycolytic cells produce relatively more ATP from glycolysis [72]. Some immune cells transition between OXPHOS and glycolytic metabolic phenotypes over the course of an immune response; manipulation of this dichotomy can have an effect on the regulation of host immunity [73]. Increased glycolysis (the Warburg effect) has been described as a feature of inflammatory as well as cancer cells (for adaptation [74]), whereas cells involved in immunoregulation or in the resolution of inflammation display FAO and an intact TCA cycle as hallmarks of their metabolism [33, 75], inevitably affecting their cellular phenotypes as will be discussed in the following subsection.

\section{Systemic metabolism and immune cell ontogeny}

\section{Macrophages and metabolism}

Macrophages have several functions in tissue homeostasis and inflammation, with their metabolic characteristics reflecting functionality [76]. Immunometabolism has been recently studied in macrophages, as metabolic pathways not only provide energy but also regulate macrophage phenotype and function $[77,78]$. In this regard, comparison between classically activated, pro-inflammatory macrophages (M1) and alternatively activated, anti-inflammatory macrophages (M2) with reparative capacity, reflecting functional polarity, is of especial relevance [73, 76]. The expression of toll-like receptors (TLRs) on the surface of macrophages promotes a M1 phenotype (mainly TLR2 and TLR4), whereas IL-4 and efferocytosis promote a M2 phenotype [79, 80]. These two phenotypes are distinct in their function as well as the preferential biological mediators produced. M1 macrophages are known for their ability to produce pro-inflammatory cytokines (IL-1 $\beta$, IL-18, IL-12, TNF- $\alpha$, IL-6) and reactive oxygen species (ROS), while M2 macrophages release anti-inflammatory cytokines (IL-4, IL-10, TGF- $\beta$ ) and promote angiogenesis and fibrosis [73, 81].

The differences between the M1 and M2 macrophage phenotypes are also evident in their cellular metabolic profiles. In general, M1 macrophages are highly glycolytic, whereas M2 macrophages use FAO metabolism and OXPHOS [37, 49, 80, 82]. In M1 macrophages, glycolysis would allow for rapid ATP production to fuel activation during acute inflammation [80, 82], while in M2 macrophages, OXPHOS occurs during the lengthy process of resolving tissue inflammation and repair or in promoting anti-parasite immunity $[80,82,83]$.

Metabolomic and transcriptomic data have provided useful insights into revealing the metabolic changes in macrophage polarization. In fact, the presence of two breaks in the TCA cycle of M1 macrophages has been described [73], thereby suggesting an "interrupted" TCA cycle for this phenotype. One of the breaks was described at the isocyanate dehydrogenase step and the other after the succinate step, with evidence for a variant of the pathway: the aspartate-arginosuccinate shunt $[41,84]$. This disruption in the TCA cycle in M1 macrophages leads to the accumulation of citrate and nitric oxide (NO) production [41]. Jha and colleagues showed that the 
TCA cycle in M1 macrophages is rather a fractionated than an undisrupted cycle [73]. Interestingly, inhibition of aspartate aminotransferase (a key enzyme in the TCA shunt pathway) suppressed IL-6 and NO production, revealing the importance of the arginosuccinate shunt for M1 macrophage function [73]. M1 macrophages convert arginine into NO through inducible NO synthase (iNOS) activity [85], while in M2 macrophages, arginine is metabolized by arginase-1 [86]. Despite the core belief that glycolysis is merely associated with inflammation and OXPHOS with anti-inflammatory responses, it is now accepted that this dogma is more fluid that previously perceived and demands revision [39, 77, 79, 80]. Macrophage metabolism remains a very interesting field especially in modalities with an urgent need for novel therapeutic targets, i.e., cancer. This subject will be discussed later.

\section{T and B cells and metabolism}

Oxidative metabolism is preferred by resting lymphocytes, where glycolysis or aerobic glycolysis meets their cellular demands after stimulation [87]. Resting precursor T-cells require energy and active replenishment of basic biological building blocks for survival and migration as they continually migrate through lymphoid tissue for immune surveillance [88]. These ATP-intensive functions are mainly achieved by FA $\beta$-oxidation as well as pyruvate and glutamine oxidation via the TCA cycle [87]. It is also known that mature resting Tcells exhibit a dynamic regulatory pattern rather than fixed metabolism [89].

During activation, and to sustain rapid clonal proliferation, the increased metabolic needs of T-cells are met by converting glucose to lactate through aerobic glycolysis - that increases glucose and glutamine metabolism while decreasing lipid oxidation as cell proliferation requires the activity of mammalian target of rapamycin (mTOR)-dependent pathways [55, 90]. It is known that OXPHOS can still be used by activated T-cells as a source of energy; however, strong evidence supports the induction of the glycolytic pathway as a lineage-decisive event for Th1, Th2, and Th1 development [89]. These lineages display a strong bias towards glycolysis over mitochondrial metabolism; Th17 development, for instance, involves hypoxia-inducible factor 1 alpha (HIF-1 $\alpha$ ), which is an oxygen-sensitive transcription factor also responsible for glycolytic gene expression regulation in Th17 cells [47, 91]. Conversely, induced Treg lineage displays a mixed metabolic signature involving glycolysis, lipid oxidation, and OXPHOS [91]. Also, blocking glycolysis during Th17 differentiation may favor Tregs over Th17 development [91], which may be detrimental in early stages of infections $[92,93]$ and potentially in patients with cancer $[94,95]$. Interestingly, decreased $\mathrm{T}$-cell proliferation and activation, T-cell anergy or cell death may be observed if inadequate nutrient supply or metabolic inhibition occur during T-cell ontogeny [89].
Much less is known about how metabolism directs the fate of normal B cells. As these cells develop into specialized antibody-secreting plasma cells and memory cells [9, 96], specific metabolic and nutritional requirements may be at play. Anergic human peripheral blood B-cells, following LPS stimulation, have been shown to only moderately increase their glycolytic rate, while unstimulated B-cells exhibited a balanced upregulation of lactate production and aerobic glycolysis concomitant with a steady increase of glucose transporter 1 (Glut1) expression following LPS or B-cell receptor (BCR) activation [97]. Indeed, BCR-mediated B-cell proliferation is stunted following inhibition of glycolysis [96], reminiscent of the scenario in activated T-cells. How B cell subsets are metabolically regulated in different human diseases and stages warrants further investigation using appropriate clinically welldefined samples.

\section{Dendritic cells and metabolism}

The activation of DCs implies phenotypic, secretory, and functional modifications that cause an increase in glucose uptake and lactate production; however, a metabolic reprogramming from OXPHOS towards glycolysis occurs after DC activation by TLRs [7, 98, 99]. During cellular activation, ATP is generated by OXPHOS, and therefore, lactate production does not reflect commitment to the Warburg effect [100]. Moreover, the need for citrate by activated DCs for fueling FAS involved in ER and Golgi apparatus turnover seems to be biochemically supported by glycolysis [100]. This glycolytic metabolism is dependent on the activation of HIF- $1 \alpha$ and PI3K/Akt pathways and indicates a possible role for mTOR downstream of PI3K/Akt [99, 101], whereas induction of the OXPHOS mediator AMPK antagonizes the glycolytic pathway, inhibiting DC maturation [102]. Nevertheless, DCs with immunogenic (promoting effector T-cells) and tolerogenic (promoting suppressive Tregs) functions have different metabolic profiles that reflect their function [103]. Tolerogenic DCs are predominantly catabolic and rely on OXPHOS and FAO for ATP production, with low glycolytic potential [103]. In contrast, immunogenic DCs exhibit anabolic metabolism and are mainly glycolytic, with reduced OXPHOS and FAO. Anabolic demands of DC activation require rapid induction of glycolysis as an integral component of TLR signaling, where the TBK1, IKKE, and Akt kinases seem to be essential for engaging the mitochondrial glycolytic enzyme HK-II [104]. The rapid loss of mitochondrial OXPHOS by TLR-triggered inflammatory DCs may be explained by the NOS-2-mediated NO production, which accompanies the glycolytic switch that is able to direct inhibit the mitochondrial ETC in an autocrine as well as paracrine manner [105]. Conventional DCs, on the other hand, do not express NOS-2 nor are they amenable to NOS-2 induction by TLRs or inflammatory cytokines [105]. An interesting insight 
into energy and mitochondrial homeostasis in DC, supporting immune activation, was highlighted by Thwe et al. in mouse DC cultures [106]. In their research, early glycolytic metabolism was observed during DC activation, supported by utilization of intracellular glycogen reserves [106]. Moreover, the authors also saw that glycogen-derived carbons preferentially contributed to the TCA-dependent citrate pool, when compared to glucose directly catabolized by mouse DCs [106]. IDO1 phosphorylation and subsequent cellular signalling in CD $11 c^{+}$, IL-4, IFN- $\gamma$ or TGF- $\beta$ activated DCs has been shown to be dependent on prior expression of Arg1 and Arg1-dependent production of polyamines [107]. The latter are either produced by DCs or released by Arg1+ myeloidderived suppressor cells (MDSCs) and may skew DCs towards an IDO1-dependent, immunosuppressive phenotype (via Src kinase activation) [107]. DC metabolism and its potential edit the quality and quantity of immune responses are likely to influence the design of immunotherapeutic strategies.

\section{Cancer, the tumor microenvironment, and metabolism}

\section{Immune cell competition for nutrients}

In a more molecular perspective, we can objectify the relationship between nutrients and immune cells through the role of the former in the control of cellular responses of the latter. In fact, there are immune microenvironments where some degree of nutrient limitation is present, which provide the opportunity to study changes in signal transduction driven by nutrients and to understand the relevance of nutrient availability in regulating immune responses (elegantly reviewed in [108]). As the concept of unequal nutrient availability to immune cells is emerging [6], competitive nutrient uptake in immune microenvironments seems to be of major importance for immune responses, hinting at nutrients' role in regulating the fate of immune cells. As will be discussed later, competition for nutrients can be observed in the tumor microenvironment (TME) and at sites of pathogen infection [108]. Solid tumors exhibit an increased demand for glucose to support growth and proliferation, despoiling extracellular levels of glucose by increasing blood supply into the TME via neovascularization [108]. There is also evidence that in some tumors, competition for glutamine may lead to limiting glutamine resource levels in the TME. This restriction of glucose and glutamine supply in the tumor seems to inhibit immune cell infiltration, as observed in local resistance to to adoptive T-cell therapy [108, 109], which will be revisited later in this review. A similar competition for nutrients has been observed in virus-infected cells, which are reprogrammed for increased glucose metabolism, glycolysis, and glutaminolysis (glutamine breakdown) and decreasing extracellular concentrations of these nutrients in the surrounding microenvironment [108, 110, 111].

\section{Role of nutrients metabolism in the TME}

The metabolism of proliferating cells is quite different from that of non-proliferating ones (which obtain energy from OXPHOS) [112]. Proliferating cells, like cancer cells, show increased requirements of energy and nutrients for rapid growth and dissemination (metastasis) and exhibit an increase in the uptake of glucose, amino-acids, fatty acids, minerals, and vitamins [113]. In fact, a central feature of nearly all cancers is impaired cellular energy metabolism [112]. To respond to the high energy demands of active proliferation, cancer cells convert great amounts of glucose into pyruvate (aerobic glycolysis), in a low-efficiency pathway - albeit their dependence on glucose for survival and growth [114]- thus the Warburg effect $[115,116]$. Cancer cells use glucose catabolism via glycolysis as a major energy-generating pathway, generating several biosynthetic molecules and NADPH. Depriving cancer cells of glucose can, in fact, promote mutations in the KRAS pathway which, in turn, induces increased sensitivity to glucose in transformed cells, leading to GLUT1 upregulation and enhanced glucose uptake from the immediate microenvironment [117]. The Warburg effect can be described as a state of mitochondrial dysfunction, as cancer cells are unable to undergo mitochondrial OXPHOS [112]. Metabolic reprogramming of cancer cells can be viewed as an enhancer of adaptation to intratumoral metabolic stress and immune surveillance, contributing to maintaining "cancer stemness" [118]. This has been considered indispensable and to the advantage of the pathological biological processes occurring in cancer cells [119].

The TME is also characterized by extracellular acidosis resulting from lactate accumulation [119-121]. This is due to the synergy between HIF- $1 \alpha$ and Myc in promoting expression of glycolytic enzymes driving glucose influx and lactate production in response to the (i) poor clearance of acid accumulation outside the TME (generating a low $\mathrm{pH}$ within the TME) and (ii) upregulation of monocarboxylate transporter (MCT) 4, favoring the migration of extracellular lactate to the extracellular matrix [114, 119]. MCT4 upregulation is especially relevant, as it is transcriptionally upregulated by the hypoxia-driven HIF- $1 \alpha \varepsilon$ enzyme, and tumor cells usually localize in hypoxic environments [122]. While not applicable to the entire TME, there may be distinct hypoxic areas due to aberrant neovascularization and subsequent impaired access to nutrients, metabolic changes that may promote disease progression [27]. Vascular endothelial growth factor (VEGF), the cardinal mediator of angiogenesis, is aberrantly expressed in several cancers and is clinically 
targeted cancers of different histology [123]. Nevertheless, it has been shown in patients with breast cancer that VEGF blockade with bevacizumab-under hypoxic conditions-leads to reoxygenation of the TME but also promotes acute hypoxia in treatment-resistant patients [124]. Anti-angiogenic therapy would deprive the tumor of nutrients necessary for survival-which would inevitably also affect the immune cell compartment therein. In fact, to escape from anticipated senescence or death, tumor cells engage autophagy to survive the potentially hostile TME $[125,126]$. Thus, overexpression of GLUT and downstream glycolytic enzymes (pyruvate kinase isozymes M2, serine hydroxymethyltransferase, carbonic anhydrase 9) [118] has been observed in several cancers [127-131]. Oncogenes (Akt, PI3K, mTOR, Ras, Raf) [132] and loss of tumor suppressor genes (VHL, PTEN, p53) also contribute to the increasing growth and metabolic activity of tumor cells [132]. Glucose can either be used in glycolysis or metabolized by PPP, promoting production of glutathione, FAs, sterols and nucleic acids, which are considered relevant for reducing oxidative stress and increasing DNA repair in cancer cells, conferring resistance to cancer treatments [133, 134]. Figure 2 presents a schematic compilation of stressors in TME.

The TME also hosts tumor-associated macrophages (TAMs), cancer-associated fibroblasts (CAFs), and endothelial cells involved in tumor stroma formation [135]. Evidence suggests that TAMs and CAFs interact in a reciprocal manner [136, 137], have a role in tumor progression [138, 139], and are associated with cancer invasion and metastasis $[135,140]$. Also, the TME is infiltrated by T-cells (tumor-infiltrating T lymphocytes, TILs), whose functions are impaired, often in association with the volume of the tumor lesion. Generally, TILs are considered a pro-inflammatory and/or cytotoxic population of T-cells able to recognize tumor antigens and, therefore, mediate tumor regression, constituting a critical clinical biomarker of prognosis $[141,142]$. The complex cellular composition of the TME, along with the hostile conditions of nutrient deprivation caused by intense energy requirements of cancer cells, imposes an important question: how do cancer

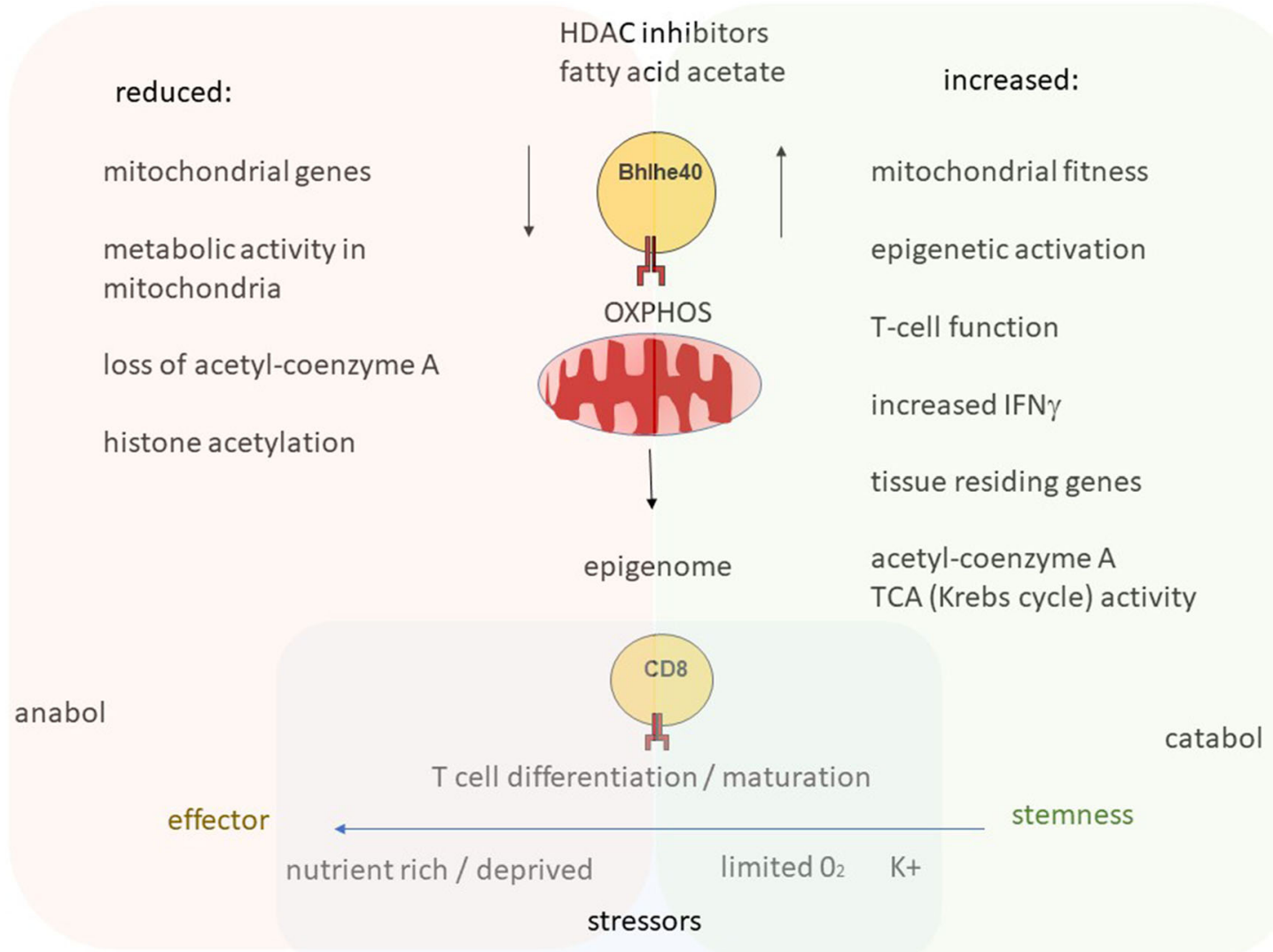

Fig. 2 Stressors, e.g., (increased) potassium, reduced oxygen and nutrient access in tissue environment, act on T cells (Li et al., Immunity, 51, 491$507,2019)$. One of the key factors modulating tissue resident $T$ cells' activity is the transcription factor Bhlhe40 (top) in infections and cancer. Reduced Bhlhe 40 leads to reduced capacity to contain infections or cancer in preclinical models, in part via effecting mitochondrial activity - that impacts on the T-cell epigenome. OXPHO (oxidative phosphorylation) and TCA activity are associated with memory immune cells. HDAC inhibitors and the fatty acid acetate replenish mitochondrial function and cytokine production. This is a simplified sketch and clinical outcomes of HDAC treatment that may be different depending on the pathogen, previous exposures of immune cells to drugs, viral and bacterial species, as well as the nominal T-cell receptor repertoire available in the microenvironment 
cells obtain enough "food" in these adverse conditions? This appears to be achieved by despoiling neighbor cells of energy and nutrients to survive and proliferate [143]. Some of these afore-mentioned nutrients, i.e., amino acids, acetate, and lactate are used as alternative fuels by cancer cells and are summarized in Table 1.

Some of these nutrients become crucial for cancer cells, which sometimes exhibit some degree of "addiction" [144, 145]. To prevent inadequate tumor perfusion due to low nutrient availability, cancer cells resort to multiple scavenging strategies to take up nutrients from cells in the immediate microenvironment [146]. These strategies include integrinmediated scavenging, receptor-mediated scavenging of albumin, and scavenging via micropinocytosis and entosis [147], as a way of obtaining final products for ATP generation and anabolism [146].

The despoiling of neighboring cells nutrients is of special concern for TILs, which is evidenced by the negative impact by the TME on TIL metabolism and its contribution to functional exhaustion of TIL, also marked by the induction of programmed cell death 1 (PD-1) expression by T-cells [148]. PD-1 is a co-inhibitor that blocks CD28-mediated activation of the mTOR pathway and reduces glycolysis but enhances FA metabolism [149]. The increase in PD-1 may facilitate the metabolic switch of energy production to TCA cycle and OXPHOS, which is observed in continuous antigen-driven stimulation during chronic infections [150]. In cancer, therapeutic targeting of PD-1+ (immunologically "exhausted") TIL has revolutionized oncotherapy and established the newly coined field of immuno-oncology [151]. Additionally, TILs must deal with the hostile environment of glucose deprivation and hypoxia, which alters their anti-tumor activity. The absence of glucose has profound effects on $\mathrm{CD} 8^{+} \mathrm{T}$-cells, as this nutrient is crucial for the differentiation of naïve $\mathrm{CD} 8^{+} \mathrm{T}$ into effector subsets [152]. Although differentiation may still occur in this situation, effector clones present reduced effector functions [153, 154]. In this context, TILs have additional challenges as the TME is a glucose-deprived environment, and regardless of high expression of GLUT1 by TILs, tumor cells are more efficient at consuming glucose [153]. Also, high concentrations of lactate in the TME lowers $\mathrm{pH}$, which inhibits PPK and consequently reduces TILs glycolysis [155]. Thus, hypoglycemia in the TME leads to reduced glycolysis, leaving TILs relying on OXPHOS. Further challenges arise with oxygen restriction; TILs face severe hypoxic conditions when infiltrating tumors from well-oxygenated peripheral blood vessels [148]. In this condition, HIF-1 $\alpha$ is activated and performs two important functions: it adjusts metabolism by enhancing TIL glycolysis due to lactate dehydrogenase A induction and increases PDK1 expression preventing OXPHOS [156-158]. Consumption of glucose is, therefore, increased to allow glycolysis to proceed. It has been demonstrated that in hypoxic conditions, T-cell activation is inhibited, with their proliferation and capacity to cytokine production reduced [159]. In fact, oxygen deprivation negatively impacts metabolism and function of TILs, as
Table 1 Non-glucose nutrients used by transformed cells as alternative fuels

\begin{tabular}{lll}
\hline $\begin{array}{l}\text { Non-glucose } \\
\text { nutrients }\end{array}$ & Essential uses by cancer cells for survival and proliferation & References \\
\hline Glutamine & Carbon and nitrogen source & {$[374-381]$} \\
& c-Myc activation & \\
& Inhibition of Akt-mediated glycolysis & \\
& Lipid biogenesis by direct supply of acetyl-CoA in hypoxic conditions or in & \\
& $\quad$ presence of IDH1 mutation & {$[382,383]$} \\
Asparagine & Redox homeostasis & \\
& Regulation of mTORC1 activation and autophagy & {$[384]$} \\
Leucine & Regulation of serine uptake and metabolism gene expression & {$[385]$} \\
Arginine & Exchanging with extracellular essential amino acids & {$[386]$} \\
Methionine & Autophagy regulation & Maintenance of viability by stability of checkpoints (mainly G1 checkpoint) \\
Cysteine & Influence epigenetic state and promotion of tumor initiation & {$[387,388]$} \\
& Reduction of cell death by oxidative stress & {$[388,389]$} \\
Serine and & ROS detoxification & Fueling one-carbon metabolism \\
glycine & Activation of PKM2, supporting aerobic glycolysis and lactate production & \\
Acetate & Activation into acetyl-CoA, used as a crucial central metabolite for TCA cycle, & {$[390-392]$} \\
& as a source of acetyl groups used for DNA acetylation modifications and for & \\
& regulation of histone acetylation and gene expression program & \\
\hline
\end{tabular}

CoA coenzyme A, mTORC1 mammalian target of rapamycin complex 1, PKM2 pyruvate kinase muscle isozyme $\mathrm{M} 2, R O S$ reactive oxygen species, $T C A$ tricarboxylic acid 
hypoxia is immunosuppressive and induces ROS accumulation in association with the apoptosis of activated TILs [160]. Thus, hypoxia in the TME inhibits OXPHOS by TILs and reprograms their metabolism to use glycolysis; however, most solid tumors combine both hypoglycemia and hypoxia to render TILs inactive in the TME. How TILs survive in these adverse conditions is still being investigated. It has been proposed that TILs may resort to using ketone bodies, similar to other cells under the same conditions [148, 161]. What seems certain is that these conditions are unfavorable for TILs impairing immune cell function, immune exhaustion and reducing anti-tumor reactivity. As cancer cells also rely on alternative nutrients for their metabolism, they affect not only the use of glucose by TILs but also other nutrients, i.e., aminoacids and FAs [162, 163]. Overall, low availability of these nutrients impairs both differentiation and cytokine production, which in turn reduces effector cytotoxic functions [164], as summarized in Table 2.

Nutrient availability also impacts metabolic pathways in TAMs, which affects their functions as well as TIL immune surveillance competence. TAMs display different phenotypes which go beyond the conventional M1/M2 dichotomy. Ultimately, five TAM phenotypes are present in the TME: activated (IL-2 ${ }^{+}, \mathrm{MCHII}^{\mathrm{hi}}$, iNOS $\left.{ }^{+}, \mathrm{TNF}-\alpha, \mathrm{CD} 80 / \mathrm{CD} 86\right)$, immunosuppressive $\left(\operatorname{Arg} 1^{+}, \mathrm{MARCO}^{+}, \mathrm{IL}-10^{+}, \mathrm{CCL} 22^{+}\right)$, angiogenic $\left(\mathrm{VEGFR} 1^{+}, \mathrm{VEGF}^{+}, \mathrm{CXCR}^{+}, \mathrm{TIE}^{+}\right)$, invasive (WNT signaling, $\left.\mathrm{EGF}^{+}, \mathrm{MMP} 9, \mathrm{CCL} 3\right)$, and metastasis-associated $\left(\mathrm{VEGFR}^{+}, \mathrm{VEGF}^{+}, \mathrm{CXCR}^{+}, \mathrm{CCR} 2^{+}\right)$macrophages [165]. The nature of the TME may edit TAMs in order to compete for nutrients, mostly glucose, which reprograms TAMs towards a phenotype consistent with tumor growth, progression and metastasis $[23,166,167]$. The central features of this metabolic reprogramming have been identified as activation of glycolysis, modifications of TCA cycle that include fueling with alternative non-glucose nutrients, FA synthesis, and altered nitrogen cycle metabolism. In cell cultures, cancer-cell stimulated macrophages have exhibited upregulation of glycolysis, increased expression of hexokinase-2, activation of AKT1/mTOR, and increased lactate receptors. Upregulation of REED1, with consequent inhibition of mTOR and glycolysis, has been observed in TAMs during hypoxic conditions. This can be linked to an augmented angiogenic response and the development of vascular leakage. Lipids and amino acids have important roles in sustaining the altered TCA cycles of TAMs. TAMs exhibit increased FA biosynthesis, uptake and storage (with important intensification of arachidonic acid metabolism), while glutamine seems relevant for macrophages polarization, especially towards a M2-like phenotype although the role of different amino acids in TAMs metabolism remains poorly studied $[168,169]$. Arg1 is upregulated in TAMs, consuming arginine for NO production and protein synthesis (reviewed in [170]). In terms of lipids, polyunsaturated (PU) FA linoleic acid (18:3) and saturated FA (SFA) stearic acid (18:0) have been considered relevant for macrophage polarization and function in TME. In fact, linoleic acid-enriched, as opposed to stearic acid-enriched TAMs, appear to exhibit cytotoxicity against some cancer cells [168]. Thus, TAMs also compete with TILs for nutrients, functionally impairing the latter (Table 2). MDSCs also play relevant roles in the TME and in modulating the efficacy of anti-cancer therapies (recently reviewed by Yan et al. [171]). Tumor-infiltrating MDSCs, as opposed to their circulating (peripheral blood) counterparts, appear to have preference for FAO as energy source in comparison, suggesting that they undergo metabolic reprogramming - like macrophages - in the TME [171]. Also, the switch from glycolysis to FAO demands an increase in lipid uptake that is associated with tumor progression and suppression of T-cells [171]. Targeting lipid metabolism in MSDCs may, therefore, be a potential target in anti-cancer strategies and warrants further investigation.

All aspects of the TME, including empowering anti-cancer ability of TILs, have been considered potential therapeutic targets for more rationally designed cancer treatments. For example, metformin treatment may improve memory $\mathrm{CD}^{+}$ T-cell responses by targeting AMPK (inducing activation) as well as mTOR (inhibitory effect leading to c-Myc and HIF-1 $\alpha$ downregulation) $[17,172,173]$, which manifest in improved FA metabolism in $\mathrm{CD}^{+} \mathrm{T}$-cells leading to memory
Table 2 Competition between cancer cells/TAMs and T-cells for non-glucose nutrients: effect of nutrient despoiling on cellular functions

\begin{tabular}{lll}
\hline Deprived by cancer cells and/or TAMs & Effect on T-cells & References \\
\hline Glutamine & $\begin{array}{l}\text { Reduced proliferative capacity and cytokine } \\
\text { production } \\
\text { Reduced effector function and survival } \\
\text { Arginine }\end{array}$ & {$[55,162]$} \\
& $\begin{array}{l}\text { Impaired memory subsets differentiation } \\
\text { Impaired TCR }\end{array}$ & {$[57]$} \\
Cystine & $\begin{array}{l}\text { Reduced proliferative capacity and cytokine } \\
\text { production } \\
\text { Tryptophan }\end{array}$ & $\begin{array}{l}\text { Downregulation of CD3- } \zeta \text { chain in CD } 8^{+} \text {T cells } \\
\text { Inhibition of Th17 differentiation }\end{array}$ \\
PUFAs & Absence of memory & {$[393-395]$} \\
\hline
\end{tabular}

PUFAs polyunsaturated fatty acids, TAMs tumor-associated macrophages, TCR T cell receptor 
Table 3 Examples of approved drugs and candidates in clinical trials targeting some TME characteristics and immunometabolism in solid tumors

\begin{tabular}{|c|c|c|c|c|}
\hline Target & Drug & Mechanism & Type of cancer & Situation (Ref.) \\
\hline \multirow[t]{6}{*}{$\begin{array}{l}\text { Hypoxia and } \\
\text { acidosis }\end{array}$} & $\begin{array}{l}\text { Panzem } \\
\text { (2-methoxyestradiol, } \\
\text { 2ME2) }+ \\
\text { temozolomid }\end{array}$ & $\begin{array}{l}\text { Inhibition of HIF- } 1 \alpha \text { and HIF- } 2 \alpha \text { protein } \\
\text { synthesis }\end{array}$ & $\begin{array}{l}\text { Recurrent glioblastoma } \\
\text { multiforme }\end{array}$ & Phase 2: NCT00481455 \\
\hline & Topotecan & $\begin{array}{l}\text { Inhibition of HIF- } 1 \alpha \text { expression, angiogenesis, } \\
\text { and tumor growth in human xenograft models }\end{array}$ & $\begin{array}{l}\text { Ovarian and small cell lung } \\
\text { cancers }\end{array}$ & $\begin{array}{l}\text { Phase 1: NCT00117013 } \\
\text { [396] }\end{array}$ \\
\hline & Metformin & $\begin{array}{l}\text { Oxygen concentration improvement in cancer } \\
\text { tissue }\end{array}$ & Head and neck SCC cancer & $\begin{array}{l}\text { Proof of principle: } \\
\text { NCT03510390 } \\
\text { (completion for } 12 / 2020)\end{array}$ \\
\hline & Everolimus (RAD001) & $\begin{array}{l}\text { Inhibition of tumor cell HIF-1 activity, VEGF } \\
\text { production, and VEGF-induced proliferation } \\
\text { of endothelial cells }\end{array}$ & Advanced renal cell cancer & $\begin{array}{l}\text { Phase 4: NCT01206764 } \\
\text { (completed, first data } \\
\text { posted 24/06/2019) }\end{array}$ \\
\hline & $\begin{array}{l}\text { Everolimus (RAD001) } \\
\quad+\text { lenvatinib }\end{array}$ & $\begin{array}{l}\text { Inhibition of tumor cell HIF-1 activity, VEGF } \\
\text { production, and VEGF-induced proliferation } \\
\text { of endothelial cells }\end{array}$ & Renal cell carcinoma & $\begin{array}{l}\text { Phase 2: NCT03324373 } \\
\quad \text { (completion for } 4 / 2021 \text { ) }\end{array}$ \\
\hline & Digoxin (DIG-HIF1) & $\begin{array}{l}\text { Inhibition of VEGFR } 1,2 \text { and } 3 \text {; FGFR 1, 2, 3, and } \\
\text { 4; PDGFR } \alpha \text {, KIT, and RET } \\
\text { Blockade of HIF-1 } \alpha\end{array}$ & Operable breast cancer & $\begin{array}{l}\text { Phase 2: NCT01763931 } \\
\quad \text { (completion for } 7 / 2020 \text { ) }\end{array}$ \\
\hline \multirow[t]{8}{*}{ Angiogenesis } & Pazopanib & $\begin{array}{l}\text { Inhibition of VEGFR, PDGFA and -B receptors } \\
\text { and c-Kit }\end{array}$ & $\begin{array}{l}\text { Advanced renal cell } \\
\text { carcinoma and soft tissue } \\
\text { sarcoma }\end{array}$ & Approved for clinical use \\
\hline & Sunitinib & Inhibition of c-kit activity & Several & Approved for clinical use \\
\hline & Sorafenib & $\begin{array}{l}\text { Inhibition of tyrosine kinase and Raf kinase } \\
\text { activity }\end{array}$ & Several & Approved for clinical use \\
\hline & $\begin{array}{l}\text { LY01008 + } \\
\quad \text { bevacizumab }\end{array}$ & Anti-VEGF; inhibition of neovascularization & Non-small cell lung & $\begin{array}{l}\text { Phase 3: NCT03533127 } \\
\quad \text { (completion for } 12 / 2020 \text { ) }\end{array}$ \\
\hline & Cediranib & Anti-VEGF; inhibition of neovascularization & Ovarian & $\begin{array}{l}\text { Phase 3: NCT03278717 } \\
\quad \text { (completion for } 12 / 2023)\end{array}$ \\
\hline & $\begin{array}{l}\text { Ramucirumab } \\
\text { (LY3009806) }\end{array}$ & Anti-VEGF; inhibition of neovascularization & $\begin{array}{l}\text { Gastric and } \\
\text { gastroesophageal } \\
\text { cancers }\end{array}$ & $\begin{array}{l}\text { Phase 3: NCT02898077 } \\
\text { (completion for } 8 / 2020 \text { ) }\end{array}$ \\
\hline & Everolimus (RAD001) & $\begin{array}{l}\text { Inhibition of VEGF production, and } \\
\text { VEGF-induced proliferation of endothelial } \\
\text { cells }\end{array}$ & Advanced renal cell & $\begin{array}{l}\text { Phase 4: NCT01206764 } \\
\text { (completed, first data } \\
\text { posted on } 24 / 06 / 2019 \text { ) }\end{array}$ \\
\hline & Aflibercept & Anti-VEGF; inhibition of neovascularization & Large choroidal melanoma & $\begin{array}{l}\text { Phase 3: NCT03172299 } \\
\quad \text { (completion for } 12 / 2024 \text { ) } \\
\text { Phase 3: NCT02885753 } \\
\text { (completion for } 6 / 2023 \text { ) }\end{array}$ \\
\hline \multirow[t]{7}{*}{$\begin{array}{l}\text { TAMS, } \\
\text { MDSCs }\end{array}$} & Pexidartinib & Inhibition of CSF1R, recruitment blockade & Giant cell & $\begin{array}{l}\text { Phase 3: NCT02371369 } \\
\quad \text { (completion for } 12 / 2019)\end{array}$ \\
\hline & PDR001 + MCS110 & Inhibition of CSF1R, recruitment blockade & Gastric & $\begin{array}{l}\text { Phase 2: NCT03694977 } \\
\quad \text { (completion for 12/2019) }\end{array}$ \\
\hline & $\begin{array}{l}\text { ARRY-382 + } \\
\text { pembrolizumab }\end{array}$ & Inhibition of CSF1R, recruitment blockade & Advanced solid & Phase 1b/2: NCT02880371 \\
\hline & Emactuzumab & Anti-CSF1R, recruitment blockade & Advanced squamous cell & $\begin{array}{l}\text { Phase 2: NCT03708224 } \\
\quad \text { (completion for } 11 / 2025)\end{array}$ \\
\hline & Cabiralizumab & Anti-CSF1R, recruitment blockade & Metastatic pancreatic & $\begin{array}{l}\text { Phase 2: NCT03697564 } \\
\quad \text { (completion for } 12 / 2021 \text { ) }\end{array}$ \\
\hline & & & Biliary tract & $\begin{array}{l}\text { Phase 2: NCT03768531 } \\
\text { (completion for } 1 / 2023 \text { ) }\end{array}$ \\
\hline & Vemurafenib & Inhibition of BRAF kinase, recruitment blockade & Metastatic melanoma & $\begin{array}{l}\text { Approved for clinical use } \\
\text { [397] }\end{array}$ \\
\hline \multirow[t]{2}{*}{$\begin{array}{l}\text { Aerobic } \\
\text { glycolysis }\end{array}$} & Dichloroacetate & Inhibition of glycolysis, by PDK inhibition & Head \& Neck SCC & $\begin{array}{l}\text { Phase 2: NCT01386632 } \\
\quad \text { (completion for } 10 / 2019)\end{array}$ \\
\hline & AZD3965 & Inhibition of glycolysis, by MCT1 inhibition & Several advanced & $\begin{array}{l}\text { Phase 1: NCT01003769 } \\
\text { (completion for } 6 / 2020)\end{array}$ \\
\hline
\end{tabular}


Table 3 (continued)

\begin{tabular}{|c|c|c|c|c|}
\hline Target & Drug & Mechanism & Type of cancer & Situation (Ref.) \\
\hline \multirow[t]{4}{*}{ Amino acids } & \multirow[t]{2}{*}{ CB-839 } & \multirow[t]{2}{*}{ Inhibition of glutamine metabolism } & $\begin{array}{l}\text { Renal cell carcinoma, } \\
\text { melanoma, and } \\
\text { non-small cell lung } \\
\text { cancer }\end{array}$ & $\begin{array}{l}\text { Phase 1: NCT02771626 } \\
\text { (concluded 6/2019) }\end{array}$ \\
\hline & & & Solid tumors & $\begin{array}{l}\text { Phase 1: NCT02071862 } \\
\quad \text { (completion for 9/2019) }\end{array}$ \\
\hline & \multirow[t]{2}{*}{ ADI-PEG } & \multirow[t]{2}{*}{ Degradation of circulating arginine } & Tumors requiring arginine & $\begin{array}{l}\text { Phase 1: NCT02029690 } \\
\quad \text { (completion for } 5 / 2020 \text { ) }\end{array}$ \\
\hline & & & Hepatocellular carcinoma & $\begin{array}{l}\text { Phase 1: NCT02102022 } \\
\quad \text { (completion for } 10 / 2020)\end{array}$ \\
\hline
\end{tabular}

$B R A F$ proto-oncogene B-Raf, $C S F 1 R$ colony-stimulating factor 1 receptor, $H I F$ hypoxia-inducible factor, $M C T$ monocarboxylate transporter, $P D G F A$ platelet-derived growth factor subunit A, $P D G F R$ platelet-derived growth factor receptors, $P D K$ pyruvate dehydrogenase kinase, RET RET protooncogene, $V E G F$ vascular endothelial growth factor, $V E G F R$ vascular endothelial growth factor receptor

generation. Table 3 shows a non-exhaustive list of approved drugs and candidates in clinical trials targeting some TME characteristics as well as immunometabolism for patients with solid cancer as a paradigm how these repurposed drugs can be used in the treatment of patients with infectious diseases (reviewed for pulmonary infections in reference [174]).

\section{Nutritional status, nutrient metabolism, and susceptibility to infection}

Infections and parasitic diseases are the most common cause of death [175] in low-income countries, where malnutrition appears to be the precipitating factor [176]. Children and adolescents with lower BMI-for-age, as well as underweight adults, are at higher risk for infections and infectionassociated morbidity and mortality [175-177], e.g., for malaria and pulmonary tuberculosis $[178,179]$. Nutrition, infection(s), and subsequently altered immune function(s) affect each other [180]: changes in nutritional status (especially energy and protein depletion) are associated with alterations in the systemic metabolism that affects immune cell regulation, immune competence, and disease susceptibility. Host factors associated with infectious diseases lead to increased metabolism (catabolism) paired with decreased appetite and subsequently to malnutritional [179]. However, the nutritional status favors maintenance of T-cells with "stem cell-like features" that are important for long-term immune memory [181].

Although malnutrition remains a concern in low-income countries, it is also present-in a "different format" in higher-income countries. Economic disparities within a country (poverty, malnutrition, and obesity) represent a major challenge for twenty-first century societies and health professionals. Obesity is no longer considered to be a consequence of the abundance of food, but rather a result of poor education, lower income, and access to affordable high-energy-dense food along with the lack of physical activity [182] and, possibly, the composition of the microbiome [183]. In general, changes in the nutritional status of populations shape immune competence, the ability to resist, fight off infections and to productively respond to vaccinations [184-186].

The relationship between malnutrition and immunity will be discussed in detail below; immunometabolism and the implications for protective immune responses and host-directed therapies have been extensively reviewed in Rao and coworkers [174].

\section{Nutritional immunology}

\section{Definition and historical aspects}

Beginning with J.F. Menkel's notes on thymic function and adequate nutrition in the nineteenth century, malnutrition has been related to alteration(s) in organs of the immune system [187]. However, the publication Interactions of nutrition and infection by Scrimshaw et al [188] in 1959 postulated the first steps pertaining to nutritional immunology. Almost a decade later, the World Health Organization (WHO) released the first edition of an extended monograph with a similar sounding concept [189]. The name of Professor Nevin Scrimshaw (1918-2013) will, thus, remain forever associated with nutritional immunology, not only due to these two publications but also owing to other works devoted to understanding the interrelationship between nutrition and infection, and the evidence of higher mortality in malnourished populations [190-198]. Since the 1969 WHO monograph, the hallmark of nutritional immunology as a discipline has been the recognition that almost any specific and sufficiently severe nutritional deficiency can interfere with 
immunological functions, affecting infectionassociated morbidity and mortality [191, 199].

\section{The synergistic relationship of nutrient reserves and immune responses}

Early observations following the advent of nutritional immunology showed that malnourished patients were more susceptible to infection and presented with an increased risk of mortality due to sepsis [200]. In fact, the impact of malnutrition on immune defense constituted, for many years, the core of and justification for immunonutrition in immunosuppressed patients - inclusively referred to as nutritionally acquired immune deficiency syndrome. The new challenges faced by humanity, mainly overnutrition, aging, and stressors, are redirecting research in the field of nutritional immunology and rewriting the applications of immunonutrition.

Nutrition and immunology have a multi-level synergistic interaction that has been described in conjunction with the 4 "Is"-Infection, Immunity, Inflammation, and Injury [31]. However, as stated above, the relationship between nutrition and immunology was first confined to the effect of poor nutrition due to the risk of infectious diseases as well as recovery after a bout of infection [191]. This was understandable in a context were nutrition was seen merely as protein and energy, and nutritional problems as "protein-energy" malnutrition (PEM). In fact, malnutrition was always a considerable clinical issue at hospital admission. Epidemiological evidence that malnutrition screening at admission and nutritional intervention during hospitalization positively impact patients' quality of life, reduce hospital stay, increase resistance to infection, and reduce costs have been instrumental recognizing the impact of nutrition in preventing and recovering from infection $[201,202]$. The relationship between PEM and infection, especially the impact on immune cells and non-cellular components are summarized in Table 4.

A relationship between nutrition and immunity was established following recognition of multiple micronutrient deficiencies which affect immune cells and other components of the immune system, for example ascorbic acid deficiency and scurvy accompanying states of malnutrition. In fact, the idea that proper nutrition also nourishes the immune system gained scientific credibility [203]. Vitamins and minerals exert profound effects on immune cells - in terms of physiology and ontogenesis - that should be considered when treating a patient. Also, the acknowledgement that nutrition may be used to re-establish immunity provides a new perspective for this adjuvant therapy. Table 5 summarizes the main effects of selected vitamins and minerals on the immune system, with significant knowledge arising from studies undertaken to obtain a better picture of nutritional deficiencies in relation to immunity.
Table 4 Relationship between protein-energy malnutrition (PEM) and infection: effects of PEM on immune cells and non-cellular components

Effect of PEM

\begin{tabular}{|c|c|c|}
\hline Innate immunity & Adaptive immunity & Organs \\
\hline $\begin{array}{l}\text { Mucus: reduced } \\
\text { production and altered } \\
\text { structure } \\
\text { Intestinal mucosa: } \\
\text { reduced integrity } \\
\text { Complement: reduced C3 } \\
\text { concentration in blood } \\
\text { NK cell: reduced activity } \\
\text { Neutrophils: reduced } \\
\text { respiratory burst and } \\
\text { bacterial killing } \\
\text { Acute phase proteins: } \\
\text { reduced concentration } \\
\text { in blood } \\
\text { Monocytes/macrophages: } \\
\text { reduced production of } \\
\text { TNF, IL-1, and IL-6 }\end{array}$ & $\begin{array}{l}\text { WBC counts: increased } \\
\text { or maintained } \\
\mathrm{CD}^{+} \text {proliferation: } \\
\text { reduced } \\
\mathrm{CD}^{+} \mathrm{CD} 4^{+} \text {: reduced } \\
\text { counts and IL- } 2 \text { and } \\
\text { IFN- } \gamma \text { production } \\
\mathrm{CD} 3^{+} \mathrm{CD} 8^{+} \text {: reduced } \\
\text { counts } \\
\text { Antibodies: increased or } \\
\text { maintained } \\
\text { concentration in } \\
\text { blood; decreased or } \\
\text { maintained response } \\
\text { to immunization; } \\
\text { reduced } \\
\text { concentration of IgA } \\
\text { in saliva and tears }\end{array}$ & $\begin{array}{l}\text { Thymus, lymph } \\
\text { nodes, spleen, } \\
\text { tonsils: reduced } \\
\text { weight }\end{array}$ \\
\hline
\end{tabular}

C3 complement protein C3, PEM protein-energy malnutrition, $W B C$ white blood cells

The increase in prevalence of chronic noncommunicable diseases and the recognition of adipose tissue as a metabolic organ with the capacity to produce specific cytokines (adipokines) and infiltrated with specialized macrophages marked the era of inflammation research. In the inflamed visceral adipose tissue, a phenotype switch in macrophages occurs, establishing the prevalence of classically activated (M1) over alternatively activated (M2) subsets. This increase in HIF- $1 \alpha$ and iNOS, thus, provides a propitious environment to metabolize L-arginine into $\mathrm{NO}$, increasing hypoxia and insulin resistance and altering the expression of adhesion molecules responsible for the homeostasis of the vascular endothelium [204-208]. This low-grade chronic inflammation underlies several pathological conditions and is considered a hallmark of obesity, diabetes, coronary arterial disease, chronic infections (tuberculosis) [209, 210], to some extent, sequelae associated with cancer $[206,211]$. The central role of inflammation and metabolism in chronic non-communicable diseases has strengthened the relationship between nutrition and immunology. "Classical" obesity and the paradigm of sarcopenic obesity have been gradually replacing PEM as major problems at hospital admission, independently of the underlying pathology [212-214]. Cachexia and sarcopenic obesity are relatively common in patients with cancer and are extremely challenging for clinicians and researchers. Skeletal muscle morphology is now recognized to reflect a relevant prognostic factor for these patients, as the role of skeletal muscle mass (SMM) and metabolism in health and 
Table 5 Relationship between nutrition and immunity: effect of selected vitamins and minerals on innate and adaptive immunity

\begin{tabular}{|c|c|c|}
\hline $\begin{array}{l}\text { Vitamins/ } \\
\text { minerals }\end{array}$ & Innate immunity & Adaptive immunity \\
\hline A & 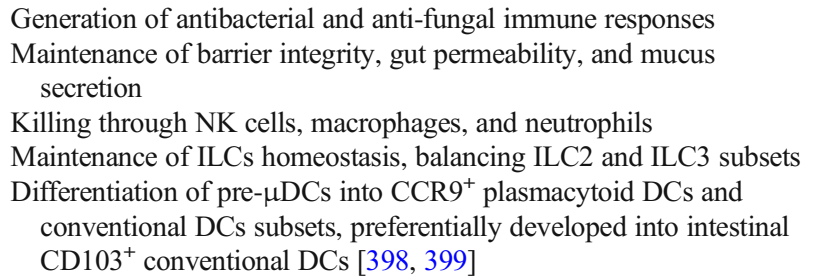 & $\begin{array}{l}\text { Promotion of gut-associated immunity by facilitating induction of } \\
\text { IgA-producing B cells, gut-tropic } \mathrm{CD} 4^{+} \text {and } \mathrm{CD} 8^{+} \mathrm{T} \text { cells, Th17, } \\
\gamma \delta \mathrm{T} \text { cells } \\
\text { Generation of mucosal and splenic } \mathrm{CD} 11 \mathrm{~b}^{+} \mathrm{DC} \text { subsets with } \\
\text { important role in the generation of } \mathrm{Th} 2 \text {, Th17, and antibody } \\
\text { responses } \\
\text { Balancing of } \mathrm{Th} 1 / \mathrm{Th} 2 \text { subsets, favoring } \mathrm{Th} 2 \text { polarization }\end{array}$ \\
\hline $\mathrm{C}$ & $\begin{array}{l}\text { Enhancing chemotaxis and phagocytosis and thereby promotes } \\
\text { microbial killing } \\
\text { Protection of phagocytes against ROS-induced damage } \\
\text { Reduction endothelial cell expression of the adhesion molecule } \\
\text { ICAM-1 in response to TNF-alpha } \\
\text { Suppression of systemic neutrophil extravasation during bacterial } \\
\text { infections } \\
\text { Inhibition of p38 MAPK pathway and endothelial NF-kappa B activity } \\
\text { Suppression of endothelial permeability and vascular leakage }\end{array}$ & $\begin{array}{l}\text { Enhancing of differentiation and proliferation of T cells, particularly } \\
\text { enhancing the selection of functional TCR } \alpha \beta \text { after the stage of } \\
\beta \text {-selection } \\
\text { Balancing of Th1/Th2 subsets, favoring Th1 and Th17 } \\
\text { differentiation } \\
\text { Increasing the induction of CTLs due to production of IL- } 15 \text { and } \\
\text { IL-12 by DCs } \\
\text { Regulation of Treg function via epigenetic regulation of Foxp3? }\end{array}$ \\
\hline $\mathrm{D}_{3}$ & $\begin{array}{l}\text { Increasing cathelicidin transcription (VDRE, } \mathrm{C} / \mathrm{EBP} \alpha, \mathrm{SWI} / \mathrm{SNF} \\
\text { complex) in monocytes/macrophages, keratinocytes, IECs, } \\
\text { placental trophoblasts, and LECs }\end{array}$ & $\begin{array}{l}\text { Suppression of IL-2 transcription in Th1, by blockade of } \\
\text { NFAT/AP1 complex and sequestration of Runx1 } \\
\text { Suppression of IFN- } \gamma \text { transcription in Th1 } \\
\text { Induction of Foxp3 transcription in Treg (VDRE in the conserved } \\
\text { non-coding region of the Foxp3 gene) } \\
\text { Suppression of IL-17 transcription in Th17, by blockade of NFAT } \\
\text { binding, sequestration of Runx1, and inhibition of ROR } \gamma \mathrm{t}\end{array}$ \\
\hline Selenium & Improving NK cell activity & $\begin{array}{l}\text { Increasing of lymphocyte proliferation } \\
\text { Increasing expression of IL-2R } \\
\text { Balancing of Th1/Th2 subsets, favoring Th1 }\end{array}$ \\
\hline Zinc & Increase of phagocytosis, NK cell activity & $\begin{array}{l}\text { Cytosolic defense against oxidative stress } \\
\text { Induction of DTH and antibody response } \\
\text { Induction of CTLs }\end{array}$ \\
\hline Iron & $\begin{array}{l}\text { Differentiation of NK cells, monocytes, and macrophages and } \\
\text { enhancing of cytotoxic activity }\end{array}$ & $\begin{array}{l}\text { Differentiation and proliferation of Th1, IL-2 production, increasing } \\
\text { in immunoglobulin levels }\end{array}$ \\
\hline
\end{tabular}

$A P$ activator protein, $D C$ dendritic cell, Foxp3 forkhead box P3, ILCs innate lymphoid cells, C/EBP $\alpha$ CCAAT/enhancer-binding protein alpha, CTL cytotoxic T-cell, DTH delayed type hypersensitivity, ICAM intercellular adhesion molecule, IEC intraepithelial cell, $L E C$ lymphatic endothelial cell, $M A P K$ mitogen-activated protein kinase, NFAT nuclear factor of activated T-cells, ROR retinoic acid receptor-related orphan receptor, SWI/SNF SWItch/ sucrose non-fermentable, TCR T-cell receptor, $T N F$ tumor necrosis factor, VDRE vitamin D response element

disease is being established [215-218]. SMM loss, as observed in sarcopenia and cancer-related cachexia, is driven by the increase of systemic inflammation [219-221]. Intracellular signaling responsible for muscle wasting is regulated by IL- 6 , TNF- $\alpha$, and transforming growth factor beta (TGF- $\beta$ ) in response to several distinct stimuli [219-222]. These cytokines have been mechanistically linked to SMM wasting and disruption of metabolic homeostasis in cancer-related cachexia [223]. Evidence also suggests that these pro-inflammatory cytokines can reduce mitochondrial biogenesis by decreasing the activity of the peroxisome proliferator-activated receptor gamma coactivator 1-alpha (PGC-1 $\alpha$ ), which in turn has an effect on nuclear respiratory factor 1 (NRF-1) and sirtuin 1 (Sirt-1) expression in cells [220]. Cachectic muscle shows increased autophagy (through induction of microtubuleassociated protein light chain 3 (LC3B) Beclin-1, p62,
Atg 5, and Bnip3, and dysregulated dynamics (increased FIS- 1 and Drp- 1 and decreased MFN-1, MFN-2, and OPA1 expression). These factors contribute to decreased mitochondrial function and ATP synthesis in skeletal muscle. Mitochondrial damage induced by mild oxidative stress can be repaired by mitophagy (targeted autophagic clearance of mitochondria), whereas high levels of oxidative stress lead to mitochondrial fission and ultimately enhanced ROS production [224]. The evidence that loss of SMM is present even when patients seem well nourished (sarcopenic obesity) is sparking more extensive research into the area of body muscle composition as compared to classical assessment based on an individual's physical stature. In patients with cancer, recovery of SMM has been related to weight maintenance, as sarcopenia is associated with delayed recovery and longer hospital stays postsurgery [225], increased susceptibility to toxicity of 
chemotherapy, and reduced quality of life and survival [226]. Therefore, SMM reflects a negative prognosis for patients with cancer and warrants greater attention in treatment regimens.

Knowing that inflammation and body composition (fat mass, SMM, free fat mass, and water) are related, it is important to also understand how nutrients may reverse chronic inflammation. Tocopherols (many with the properties of vitamin E), retinol (vitamin-A1-alcohol), zinc, essential fatty acids (omega-3/omega- 6 balance), amino acids and nucleotides are able to modulate the intensity of inflammatory responses, more specifically metaflammation or chronic metabolic inflammation [227]. This may in part be responsible why individuals in countries with a high burden of infectious diseases are more susceptible to severe pathology, as many of those who succumb to infectious diseases under-nourished, particularly children [228]. Perinatal nutrition and supply of micronutrients to neonates, including via breast feeding, has already been discussed in light of their paramount importance in priming innate immune responses against bacterial infections in very early childhood $[229,230]$. While nutrition is indispensable for muscle mass anabolism, the regulation and fine-tuning of inflammation and immune cell composition in tissue compartments by micronutrients deserves a closer look in clinical studies. It is, therefore, necessary to design future clinical trials (vaccines, drugs, immunotherapy) and treatment plans with the inclusion of the fundamental aspects of nutrition, metabolism, and inflammation.

The relationship between nutrition and immunology can also be extended to injury. It has been widely accepted that nutrition and wound healing are closely related, so that proper nutrition is required to allow progression through all stages of wound healing: inflammatory, proliferative, and remodeling/ maturation phases. PEM or nutrient deficiencies negatively impact wound healing by extending the inflammatory phase, decreasing fibroblast proliferation, and reversing collagen synthesis [231]. Malnourished patients are recognized to be at risk of pressure ulcers, infections, delayed wound healing, and chronic non-healing.

Nutrition has been considered one of the most relevant modifiable factors influencing chronic non-communicable diseases. The importance of nutrition is being increasingly recognized by clinicians as a biologically and clinically factor in clinical performance and recovery [232-234], more well-designed clinical studies are need combining clinical endpoints with biological marker analyses, particularly in patients with cancer [235-239]. Recent data from the PREDyES® study revealed that nutritional risk is present at hospital admission in $33.9 \%$ of patients, with an increase at discharge from hospital $(36.4 \%)$ [239]. In a recent report involving a prospective cohort including 1588 patients with cancer, Byung-Gon $\mathrm{Na}$ and colleagues demonstrated that malnutrition appears to be more frequent in patients with esophageal, pancreaticobiliary, or lung cancer $(52.9 \%, 47.6 \%$, and $42.8 \%)$, followed by stomach, liver, and colon cancers $(29.1 \%, 24.7 \%$, and $15.9 \%$, [240]. Also, malnourished, patients with cancer who underwent surgical procedures had longer hospital stays and poorer quality of life than those who were well nourished [240].

Nutritional immunology is now considered clinically relevant, to pave the way for novel research paths with the ultimate aim to provide improved nutrition, increased, competent immune function and overall 'better' healthcare.

\section{The role of the microbiome in regulating nutrient bioavailability and immune responses}

The study of the microbiome is an emerging area of research with an influence on all aspects of health - cancer [241-243], depression [244], metabolic disease [245], and susceptibility to and control of infections [246, 247]. The gut microbiota is directly involved in the metabolism of drugs [248], thus forming an additional layer of pharmacokinetics further to the role of the liver and kidneys in relation to treatment efficacy.

The gut is considered a unique organ in humans due to the sheer diversity of microflora performing a myriad of functions, in addition to its direct exposure to the external environment. A healthy microbiome - also in other mucosal tissues, i.e., lungs, skin, gums - is directly associated with general well-being [249]. There are psychological, environmental, and physical stressors that affect microbiome composition and function (reviewed in [250]). A major nutritional component linked to immune regulation are short- and long-chain fatty acids (SCFAs and LCFAs) produced by gut commensals. These have been shown to influence memory T-cell formation and maintenance as well as activation of effector cell populations in tissue [251]. The biosynthesis of micronutrients such as vitamins and amino acids by gut commensals including lactic acid bacteria (LAB) would - in the first placeaffect the physiology of parenchymal tissues, i.e., epithelialcell functions, for instance [252]. In fact, the microbiome is also responsible for biosynthesis of vitamins like cobalamin, folic acid, biotin, thiamine, riboflavin, nicotinic acid, pyrodixine, pantothenic acid, and vitamin $\mathrm{K}[252,253]$. The potential link between SMM and gut dysbiosis, particularly with respect to aging, is being actively explored. Changes in gut microbiota composition have been related to enrichment of certain bacterial species, i.e., Bacteroidetes sp., Escherichia sp., and reduced frequencies of Ruminococcus sp. which have been observed in individuals older than 65 years of age in northern Europe [254, 255]. Also, SMM due to aging has been associated with gut microbiota alterations, which contribute to increased risks of systemic inflammation as well as fat accumulation in skeletal tissue [256]. Consumption of particular types of food have also been investigated as inducers of 
predictable alterations in existing host microbiota (reviewed in [257]). All dietary proteins contribute to microbial diversity; however, the sources of the protein seem to determine the effect on specific bacterial genera. Animal proteins, particularly red meat, favor Bacteroides, Alistipes, Bilophila, and Ruminococcus, while reducing Bidobacterium; this phenomenon has been associated with increased levels of trimethylamine- $N$-oxide (proatherogenic) [258] and reduction of SCFA [257]. Proteins of plant origin favor Bidobacteria and Lactobacillus and reduce Bacteroides and Clostridium perfringens, which has been associated with increased production of SCFA and an improved gut barrier, Treg induction, and amelioration of inflammation [257]. Unsaturated fat favors Streptococcus, Lactobacillus, and Bifidobacteria that seem to downregulate TLR activation and white adipose tissue inflammation, while saturated fat is associated with increases in Bacteroides, Bilophila, and Faecalibacterium prausnitzzi promoting white adipose tissue inflammation, TLR activation and impaired insulin sensitivity [257, 259, 260]. Concerning carbohydrates, natural and artificial sweeteners promote different effects on microbiota composition: natural sweeteners tend to increase Bifidobacteria and reduce Bacteroides, while artificial sweeteners seem to have the opposite effect [257]. There is no doubt that the Western diet is associated with dysbiosis (increase in Bacteroides and Enterobacteria and reduction in Bifidobacteria, Lactobacillus, and Eubacteria) [261], while the Mediterranean diet appears to have opposite and beneficial effects on the gut microbiome [262]. In this context, both obesity and malnutrition (despite the few studies available) have a severe impact on gut microbiota as well as individual micronutrient deficiencies [263]. Malnutrition results in persistent impaired maturation of the intestinal microbiota that seems difficult to revert even with refeeding [264]. As such, this topic deserves further investigation in multicohort clinical studies. A healthy "microbiome" does not sufficiently describe the commensal-host relationship and different layers of shaping immune responses. Analysis of the "dark viral matter," i.e., known and not yet known viral sequences in the gut revealed that a healthy gut microbiome is defined by integrated prophages versus the shift from lysogenic to lytic replication, associated with inflammatory bowel disease [265, 266].

Pertaining to individual micronutrients, vitamin $\mathrm{D}$ is an interesting but somewhat controversial paradigm. Vitamin D is necessary for the biosynthesis of cathelicidin (human LL37), a crucial antimicrobial peptide that is also produced in the gut and linked to the IFN- $\gamma$, IL-32, and IL-15 signaling axis [267, 268]. Several studies have gone further to show that LL37 has anti-cancer properties based on its ability to kill cancer cells in vitro (reviewed by Kuroda et al. in [269]). LL-37 bioavailability in the colon, however, can affect gut microbiota viability and potentially perpetrate dysbiosis, as shown in chickens in the context of CATH-2 [270]. However, mice lacking the antimicrobial peptide CRAMP (CRAMP-KO) displayed oral dysbiosis following co-housing with wildtype mice, possibly transferred to the gut of the CRAMP$\mathrm{KO}$ animals due to CRAMP presence in the feces of the latter [271]. Strikingly, CRAMP-deficient mice exhibited compromised intestinal morphology, i.e., reduced crypt length but increased inflammatory events leading to tissue enlargement. Due to the very high likelihood of inter-organ communication pathways, i.e., gut-lung axis, LL-37 produced in the lungs during an acute bacterial infection could translocate to the bowel and eliminate certain commensal populations - a phenomenon which can also occur in vice versa, at least with regard to microbial metabolites and immune cells [272-274]. Further clinical studies in addition to relevant and well-designed translational models are necessary to better understand how antimicrobial peptide biology plays into nutrient uptake and immune response development in humans. For instance, fecal microbiota transplantation (FMT) for the treatment of recurrent Clostridium difficile infections (CDI) leads not only to clinical improvement in patients but also the establishment of a corrective mechanism to introduce gut-friendly commensals which would compete with C. difficile for nutrients and ameliorate pathology [275]. Correcting the local immunoregulatory networks using FMT also appears to be clinically beneficial in patients with ulcerative colitis [276], where prebiotic therapy helps remodel damaged colon tissue, as is likely the case in recurrent CDI. It would be helpful if a more broader, objective appreciation of mucosal dysbiosis could be performed. This could help to devise more robust clinical studies measuring immune-competence and clinical endpoints in patients with infectious diseases or cancer.

Diet is most often seen as having a circular relationship with the microbiome. However, it has been proposed that a distinction be made between the role of the microbiome in mediating the effects of diet on metabolism and the microbiome itself as a modifier of the host response to diet [277].

\section{Future directions: is there a role for tailor-made nutrition in cancer and infections?}

\section{Cancer cachexia, muscle wasting, and metabolism}

Along with the immunosuppression that results from a reprogrammed TME, patients with cancer experience profound alterations in body composition as a result of wasting disease and anti-cancer directed treatments [278]. These alterations are most evident in SMM, as muscle as well as adipose tissue wasting are common features in cancer (affecting nearly 
$80 \%$ of late-stage patients) and the major causes of morbidity and mortality [279]. As SMM and adipose tissue are depleted during cancer progression, patients experience weakness, frailty, and loss of mobility [280], followed by a rapid decline in total body weight and severe compromise of immune functions [223]. SMM and adipose tissue depletion are closely connected to increased levels of TNF- $\alpha$, IL-1, and IL- 6 , the key mediators of cancer-associated cachexia [281-283]. TNF- $\alpha$ has a direct catabolic effect on MM by induction of the ubiquitin-proteasome system (full form), which dictates an increase in gluconeogenesis, proteolysis and a decrease in protein, lipid, and glycogen synthesis [283]. A comprehensive review of the metabolic changes during cancer cachexia was published recently [284]. However, besides the knowledge that patients with cancer present with hypermetabolism induced by cachexia [285], the effective role of metabolism in muscle consumption deserves further investigation. Patients with cancer exhibit altered glucose metabolism clearly marked by sluggish glucose uptake, reduction of the conversion rate of glucose to glycogen, lactate or $\mathrm{CO}_{2}$, and suppression of enzymes that support glycolysis and glucose oxidation [284]. Lipogenesis has been found to be lower in preclinical cachexia (murine) models. However, lipolysis and FAO rates seem similar in patients with cancer and healthy controls during fasting [286, 287]. Not only protein synthesis and degradation contribute to muscle atrophy, yet also age-related defects in autophagy signalling $[288,289]$. In fact, p38 $\beta$ MAPK was identified as a key mediator of cancer-induced autophagy activation in SMM of tumor-bearing mice [290]. The authors demonstrated that this occurs through ULK1 activation and upregulation of C/EBP $\beta$-controlled LC3b and Gabarapl1 genes [290]. Fukawa and colleagues also demonstrated, using human muscle stem cell-based models and human cancerinduced cachexia models in mice, that progressive muscle wasting was associated with excessive FA catabolism triggered by complex pro-inflammatory factors, increased oxidative stress, and activation of the p38 signaling pathway [279]. Mitochondrial dysfunction also seems to underlie SMM consumption in cancer [220], with mitochondrial dynamics and mitophagy signaling being identified as aberrant checkpoints of the muscular-mitochondrial quality control axis associated with cancer cachexia [291].

Chemotherapy-induced cachexia was recently associated with metabolic dysregulation [292]. In a murine Colon26 adenocarcinoma xenograft model, the authors compared the metabolic derangements associated with cancer-induced cachexia with a chemotherapy-induced cachexia model using FOLFIRI (5-fluorouracil, irinotecan, and leucovorin) [292]. Using metabolomic techniques, FOLFIRI-induced cachexia perpetrated slightly higher amino acid catabolism and carbon flux through the TCA cycle and $\beta$-oxidation pathways, as compared with cancer cachexia per se [292]. This study highlights the heterogeneity of cachectic phenotypes induced by cancer and chemotherapy may be considered in future study designs. Other clinical studies and reviews drawn a link between chemotherapy and cachexia induction [293-295] as well as overall body composition [296-299]. This reveals that cancer- and treatment-induced cachexia is complex, multifactorial, and personalized for each patient, especially in respect of the circulating mediators secreted and pathways disrupted. The understanding that this complexity and singularity makes each patient unique, strongly argues for nutrition as an integral component of personalized cancer treatment.

\section{Immunonutrients: cancer and infection}

Attempts to manipulate the complex network of cells and circulating molecules of the human immune system have been made throughout modern medical history. Considering nutrition as part of these attempts, publications on the dietary manipulation of inflammatory responses date back to the late 1980s and early 1990s [300-303]. Nutrients studied for their possible role on modulating immune responses were considered "immunonutrients," wherein important contributions have been made by Robert F. Grimble (main reviews [200, 301, 304, 305]). Immunonutrients have been historically divided into omega 3 PUFAs (EPA and DHA), sulfurcontaining amino acids, their precursors and other thiol compounds (methionine, cysteine, $\mathrm{N}$-acetyl cysteine and L-2oxothiazolidine-4carboxylate lipoic acid), glutamine, arginine, and nucleotides [200]. Other nutrients such as antioxidants can also be used for this purpose [306]. These immunonutrients have been studied in supra-physiological doses, administered enterally or parenterally, to achieve some degree of immune response modulation in different pathological conditions [200, 301]. The role of nutrients for immune cell function and competence was discussed earlier in this review. Therefore, profound metabolic and immunological alterations characteristic of cancer provide a unique opportunity for the study of nutritional modulation, especially in the age of personalized precision medicine.

Currently, the nutritional recommendations for patients with cancer, among other aspects, require the following: (i) provision of adequate nutrition to prevent malnutrition, (ii) avoidance of dietary provisions that restrict energy intake in patients with or at risk of malnutrition, (iii) avoidance of supplementation with branched-chain or other amino acids as well as metabolites to improve fat-free mass, and (iv) supplementation with EPA and DHA or fish oil to stabilize or improve appetite, food intake, lean body mass, and body weight [307]. However, some research questions were raised in these guidelines: the influence of fasting or diets mimicking the effects of anti-cancer drugs, the effect of leucine or hydroxy methylbutyrate in unwanted weight loss assessed by large randomized clinical trials (RCTs), the effect of EPA and DHA on body composition and clinical outcome in patients 
with cancer undergoing treatment, and the effect of omega 3 on quality of life (QoL) and clinical outcome in cachexic patients with cancer. These recommendations, nevertheless, are in need of well-designed clinical trials to obtain solid real-world evidence for clinical practice. Another important issue is the missing link between the nutritional and immunological variables in most clinical studies. Commonly, nutritional publications on the effect of nutrition in clinical outcomes do not account for immunological profiles or immune response parameters. Published studies describing the effect of a single nutrient on immunity or inflammation frequently fail to consider the evaluation of dietary intake or body composition. This is also true for studies evaluating the effect of immunonutrition in cancer.

Three fundamental aspects should be addressed when considering immunonutrition administration and its effect on the overall result: (i) route and (ii) timing of administration as well as (iii) genetic variation among patients [200, 308]. Immunonutrition may be delivered enterally or parenterally, as single nutrient(s) or combinations of two or more immunonutrients. In the early days of immunonutrition, enteral or parenteral formulas were the preferred route for administration of immunonutrients, as the need to resort to artificial nutrition was an opportunity to test the usefulness of these nutrients [309, 310]. Enteral delivery of immunonutrients may be achieved by tube feeding or using oral nutritional supplements (ONS). Currently, oral formulations as capsules are also used, alone or in combination with ONS [311, 312]. The major difference between parenteral and enteral routes is that when the latter route is used, metabolic processing by the liver is bypassed, affecting clinical outcome [200]. Although debated for several years now, there is no consensus on the best route for immunonutrition administration [31, 200, 313, 314]. Regarding timing, preoperative administration of immunonutrition has been studied in the context of surgical critical care, cancer surgery [315-320], as well as perioperative administration [321-323]. Whether immunonutrition should be delivered at the peak of or prior to an inflammatory response remains to be answered. Genetic variation is also an important factor to be considered when evaluating immunonutrition efficacy [324-326]. Hundreds of genes may shape host response to nutrition, contributing to some degree of variability in results with immunonutrients [327-329]. Among others, single-nucleotide polymorphisms (SNPs) have been associated with lipemia owing to dietary lipids and the ability of fish oil to abate TNF production [330-332].

Studies on the effect of single immunonutrients or immunonutrition formulas are heterogenous pertaining to the routes of administration, time of initiation and duration of immunonutrition treatment, the number and characteristics of patients, cancer diagnoses, as well as the outcomes evaluated. Gastrointestinal (GI) malignancies are prevalent worldwide with a vast impact on nutritional status [333-336]. Table 6 presents a compilation of clinical trials on the effect of immunonutrition on GI cancers addressing body composition and immunological parameters/immune responses as outcomes published for the 10 years. Besides several ongoing clinical trials with immunonutrients in cancer, an interesting phase $2 \mathrm{~b}$ clinical trial on the effect of omega 3 supplementation before radical prostatectomy on prostate cancer proliferation, inflammation, and QoL (NCT02333435) is expected to be concluded in due course [337]. Once again, this study does not address whether immunonutrition may contribute to modulation of immune cell phenotype, especially in the TME. In-depth immunological analyses are desirable in future clinical studies assessing complete dietary evaluation and full nutritional status assessment of patients prior and after intervention.

Beyond classical immunonutrients, other dietary interventions are currently under investigation for their potential to modulate the TME. One example is fasting, fastingmimicking diets, and ketogenic diets [338]. Metabolic pathways are activated in response to caloric restriction, promoting inhibition of the mTORC1 pathway to contribute to reduced cancer growth. Additionally, modulation of the ATP/ADP and NADPH/NADP+ ratio, reduction of acetyl-CoA, and decreased serum insulin, glucose, and IGF-1 levels have been associated with caloric restriction [338]. Although not yet recommended for clinical practice (as already discussed here), research in this area is aligned with open questions raised by scientific societies [307]. Fasting, long-term fasting, fasting-mimicking diets, and ketogenic diets are currently under investigation in lung (NCT03700437; NCT01419587), breast (NCT03595540, NCT03162289, NCT01304251; NCT03962647; NCT03535701; NCT02092753), colorectal (NCT03595540), ovarian (NCT03162289), pancreatobiliary (NCT03510429; NCT02964806), pancreatic (NCT01419483), head and neck (NCT01975766), and prostate (NCT02710721) cancers, as well as malignant CNS tumors (NCT03451799; NCT03278249; NCT03075514; NCT02983942; NCT02939378; NCT02302235; NCT02046187; NCT01865162; NCT01754350; NCT01092247; NCT00575146) and studies involving multiple indications (NCT03340935, NCT01954836, NCT01175837, NCT00936364; NCT03162289; NCT03160599; NCT00936364; NCT01175837; NCT01716468; NCT02516501).

Apart from restriction in total calorie intake, restricting specific nutrients may also be an interesting addition to therapeutic strategies. It has been proposed that specific nutrient deprivations, for example $\mathrm{K}^{+}$, may allow TILs to persist in the TME in a less differentiated status associated with strong antitumor responses, rather than contribute to T-cell limitation as it is observed for other nutrients [339]. This hypothesis has 
Table 6 RCTs testing the effect of immunonutrition on nutritional and immunological outcomes in digestive cancers, published during the last 10 years

\begin{tabular}{|c|c|c|c|c|c|c|c|}
\hline \multirow[t]{2}{*}{ Study (ref.) } & \multirow[t]{2}{*}{ Participants } & \multicolumn{4}{|c|}{ Intervention } & \multirow[t]{2}{*}{ Outcomes } & \multirow[t]{2}{*}{ Results } \\
\hline & & Type & Route & Daily dose & Timing & & \\
\hline $\begin{array}{l}\text { Ida et al., } 2017 \\
\text { [400] }\end{array}$ & $\begin{array}{l}\text { Gastric cancer } \\
\text { undergoing } \\
\text { gastrectomy } \\
N=63(46 \text { males }) \\
65.1(31-79) \text { years }\end{array}$ & Omega 3 & $\begin{array}{c}\text { Enteral } \\
\text { ONS }\end{array}$ & $2.3 \mathrm{~g} \mathrm{EPA}$ & $\begin{array}{l}7 \text { days to } 1 \text { day prior } \\
\text { to surgery }\end{array}$ & $\mathrm{BW}, \mathrm{CRP}$ & No effect \\
\hline $\begin{array}{l}\text { Miyata et al., } \\
2017 \text { [401] }\end{array}$ & $\begin{array}{l}\text { Esophageal cancer } \\
N=31(27 \text { males }) \\
64.5 \pm 8.4 \text { years }\end{array}$ & Omega 3 & $\begin{array}{l}\text { Enteral } \\
\text { ONS }\end{array}$ & $900 \mathrm{mg}$ EPA + DHA & $\begin{array}{l}\text { After CT initiation } \\
\text { from day } 3 \text { to day } \\
12 \text { (total: } 10 \text { days) }\end{array}$ & $\begin{array}{l}\text { Caloric intake } \\
\text { BW, IL-6, TNF- } \alpha \\
\text { Toxicity }\end{array}$ & Reduced toxicity \\
\hline $\begin{array}{l}\text { Sorensen et al., } \\
2014 \text { [402] }\end{array}$ & $\begin{array}{l}\text { CRC undergoing } \\
\quad \text { surgery } \\
N=74 \text { (44 males) } \\
69 \pm 11 \text { years }\end{array}$ & Omega 3 & $\begin{array}{l}\text { Enteral } \\
\text { ONS }\end{array}$ & $\begin{array}{l}2 \mathrm{~g} \text { EPA } \\
1 \mathrm{~g} \mathrm{DHA}\end{array}$ & $\begin{array}{l}7 \text { days before } \\
\text { surgery }\end{array}$ & $\begin{array}{l}\text { 5-HEPE, 5-HETE } \\
\text { LTB5, LTB4 }\end{array}$ & $\begin{array}{l}\text { Reduction in LTB4 } \\
\text { production } \\
\text { Increase in LTB5 and } \\
\text { 5-HEPE } \\
\text { production }\end{array}$ \\
\hline $\begin{array}{l}\text { Mocellin et al., } \\
2013 \text { [403] }\end{array}$ & $\begin{array}{l}\text { CRC undergoing } \\
\quad \text { CT } \\
N=6 \text { ( } 3 \text { males }) \\
55.2 \pm 7.7 \text { years }\end{array}$ & Omega 3 & $\begin{array}{l}\text { Oral } \\
\text { Capsules }\end{array}$ & $\begin{array}{l}350 \mathrm{mg} \text { EPA } \\
240 \mathrm{mg} \text { DHA }\end{array}$ & 9 weeks & $\begin{array}{l}\text { IL-1 } \beta, \text { IL-10, } \\
\text { IL-17A, TNF- } \alpha \text {, } \\
\text { CRP, BW, } \% \text { BF, } \\
\text { LM }\end{array}$ & $\begin{array}{l}\text { Reduction of CRP } \\
\text { levels }\end{array}$ \\
\hline $\begin{array}{l}\text { Silva et al., } 2012 \\
\quad \text { [404] }\end{array}$ & $\begin{array}{l}\text { CRC undergoing } \\
\text { CT } \\
N=11 \text { ( } 8 \text { males }) \\
50.1 \pm 8.2 \text { years }\end{array}$ & Omega 3 & $\begin{array}{l}\text { Oral } \\
\text { Capsules }\end{array}$ & $\begin{array}{l}600 \mathrm{mg} \text { EPA + DHA } \\
3 \mathrm{mg} \text { cholesterol }\end{array}$ & 9 weeks & $\begin{array}{l}\text { TNF- } \alpha, \text { IL-1 } \beta, \text { IL- } 6 \text {, } \\
\text { CRP, BW }\end{array}$ & $\begin{array}{l}\text { Reduction of CRP } \\
\text { levels } \\
\text { Improved BW }\end{array}$ \\
\hline $\begin{array}{r}\text { Bonatto et al., } \\
2012 \text { [405] }\end{array}$ & $\begin{array}{l}\text { Gastrointestinal in } \\
\text { CT and after } \\
\text { surgery } \\
N=19(12 \text { males }) \\
53.8 \pm 2.4 \text { years }\end{array}$ & Omega 3 & $\begin{array}{l}\text { Oral } \\
\text { Capsules }\end{array}$ & $\begin{array}{l}300 \mathrm{mg} \text { EPA } \\
400 \mathrm{mg} \text { DHA }\end{array}$ & 8 weeks & $\begin{array}{l}\text { Number and function } \\
\text { of PMN } \\
\text { BW }\end{array}$ & $\begin{array}{l}\text { Maintenance of PMN } \\
\text { number and } \\
\text { function } \\
\text { Improved BW }\end{array}$ \\
\hline $\begin{array}{l}\text { Trabal et al., } \\
2010 \text { [406] }\end{array}$ & $\begin{array}{l}\text { Advanced CRC in } \\
\quad \text { CT } \\
N=8(4 \text { males }) \\
61.5 \pm 15.8 \text { years }\end{array}$ & Omega 3 & $\begin{array}{l}\text { Enteral } \\
\text { ONS }\end{array}$ & $1.6 \mathrm{~g} \mathrm{EPA}$ & 12 weeks & BW, dietary intake & $\begin{array}{l}\text { Improved BW and } \\
\text { appetite }\end{array}$ \\
\hline $\begin{array}{l}\text { Rotovnik } \\
\text { Kozjek et al., } \\
2011 \text { [407] }\end{array}$ & $\begin{array}{l}\text { Rectal cancer } \\
\text { receiving RT } \\
N=14 \text { (no reference } \\
\text { to gender } \\
\text { distribution) } \\
60.5 \pm 4.2 \text { years }\end{array}$ & AA & $\begin{array}{l}\text { Oral } \\
\text { Powder }\end{array}$ & 30 g glutamine & $\begin{array}{l}\text { At start of RT and for } \\
\text { subsequent } \\
5 \text { weeks }\end{array}$ & $\begin{array}{l}\text { IL-6, blood count } \\
\text { CRP }\end{array}$ & Reduction of IL-6 \\
\hline $\begin{array}{l}\text { Martin et al., } \\
2017 \text { [315] }\end{array}$ & $\begin{array}{l}\text { Pancreatic cancer } \\
\quad \text { undergoing } \\
\quad \text { surgery } \\
N=44 \text { (30 males) } \\
60(27-61) \text { years }\end{array}$ & Combined & $\begin{array}{l}\text { Enteral } \\
\text { ONS }\end{array}$ & $\begin{array}{l}12.6 \mathrm{~g} \mathrm{~L} \text {-arginine } \\
3.3 \mathrm{~g} \mathrm{EPA}+\text { DHA } \\
1.29 \mathrm{~g} \mathrm{RNA}\end{array}$ & $\begin{array}{l}5 \text { days prior to } \\
\text { surgery }\end{array}$ & BW, NRI & Decrease in NRI \\
\hline $\begin{array}{l}\text { Seguin et al., } \\
2016 \text { [408] }\end{array}$ & $\begin{array}{l}\text { Liver cancer } \\
\quad \text { undergoing } \\
\quad \text { surgery } \\
N=18 \text { (14 males }) \\
68 \pm 6 \text { years }\end{array}$ & Combined & $\begin{array}{l}\text { Oral } \\
\text { Powder }\end{array}$ & $\begin{array}{l}11.4 \mathrm{~g} \text { L-ARGININE } \\
3 \mathrm{~g} \text { EPA } \\
1.2 \mathrm{~g} \text { RNA }\end{array}$ & $\begin{array}{l}10 \text { days prior to } \\
\text { surgery }\end{array}$ & $\begin{array}{l}\mathrm{CD}^{+}, \mathrm{CD}^{+}, \mathrm{CD}^{+}, \\
\mathrm{NK}, \mathrm{B} \text { cells, } \\
\text { phagocytosis } \\
\text { capacity }\end{array}$ & $\begin{array}{l}\text { Increased } \\
\text { phagocytosis } \\
\text { capacity in } \\
\text { monocytes }\end{array}$ \\
\hline $\begin{array}{r}\text { Marano et al., } \\
2013 \text { [409] }\end{array}$ & $\begin{array}{l}\text { Gastric cancer } \\
\quad \text { undergoing } \\
\text { surgery } \\
N=54(34 \text { males }) \\
66.6(55-78) \text { years }\end{array}$ & Combined & $\begin{array}{l}\text { Enteral } \\
\text { Tube feeding }\end{array}$ & $\begin{array}{l}24 \mathrm{~g} \text { L-arginine } \\
3.3 \mathrm{~g} \text { EPA + DHA } \\
2.3 \mathrm{~g} \text { RNA }\end{array}$ & $\begin{array}{l}\text { From } 6 \mathrm{~h} \text { after } \\
\quad \text { surgery to } 7 \text { th day }\end{array}$ & $\begin{array}{l}\mathrm{CD}^{+}, \mathrm{CD}^{+}, \\
\quad \text { leukocyte count }\end{array}$ & $\begin{array}{l}\text { Less impact of } \\
\text { surgery on } \mathrm{CD}^{+}\end{array}$ \\
\hline $\begin{array}{l}\text { Okamoto et al., } \\
2009 \text { [410] }\end{array}$ & $\begin{array}{l}\text { Gastric cancer } \\
N=30(20 \text { males }) \\
66.9 \pm 11.5 \text { years }\end{array}$ & Combined & $\begin{array}{l}\text { Enteral } \\
\text { ONS }\end{array}$ & $\begin{array}{l}9.6 \mathrm{~g} \text { L-arginine } \\
3.1 \mathrm{~g} \text { EPA + DHA } \\
0.96 \mathrm{~g} \text { RNA }\end{array}$ & $\begin{array}{l}7 \text { days prior to } \\
\text { surgery }\end{array}$ & $\begin{array}{l}\mathrm{CD}^{+}, \mathrm{CD}^{+}, \mathrm{CD}^{+}, \\
\mathrm{NK}, \text { phagocytosis } \\
\text { capacity, } \\
\text { HLA-DR } \\
\text { expression on } \\
\text { monocytes, BW }\end{array}$ & $\begin{array}{c}\text { Maintenance of } \\
\mathrm{CD}^{+}, \mathrm{CD} 4^{+}, \\
\mathrm{CD}^{+}, \mathrm{NK}\end{array}$ \\
\hline
\end{tabular}

Age is presented as mean \pm standard deviation or median (range)

$A A$ amino acids, $B F$ body fat, $B W$ body weight, $C R C$ colorectal cancer, $C R P$ C-reactive protein, $C T$ chemotherapy, $D H A$ docosahexaenoic acid, $E P A$ eicosapentaenoic acid, HEPE hydroxyeicosapentaenoic acid, HETE hydroxyeicosatetraenoic acid, $L M$ lean mass, $L T$ leukotriene, $N K$ natural killer, $N R I$ nutritional risk index, $O N S$ oral nutritional supplements, $P M N$ polymorphonuclear leukocytes, $R N A$ ribonucleic acid, $R T$ radiotherapy 
been explored in publications [339-341] and deserves further clinical investigation.

Immunonutrients are less well studied within clinical trials concerning MTB. Experimental studies suggested that EPA and DHA may improve host defense against infections by limiting excessive inflammation and improving immune responses [342]. For example, in an experimental study with guinea pigs infected with M. tuberculosis, McFarland and colleagues demonstrated that omega 3 intake $(13 \% w / w)$ for 3 or 6 weeks was associated with decreased lymphoproliferative responses and increased lung bacterial load compared to intake of omega 6-enriched diet [343]. Transgenic mice (producing PUFAs endogenously, Fat-1-trangenic mice) were demonstrated to be more susceptible to MTB infection compared to WT [344]. On the contrary, experimental incorporation of amino acids seems to stimulate TNF- $\alpha$ production by M. tuberculosis-infected macrophages along with antibacterial activity [345]. Epidemiological studies on this subject have provided conflicting results. In selected populations as the Inuit, higher intake of fish has been associated to increased MTB incidence [346-348]. Yet in a large cohort of Chinese men and women $(63,257$ participants aged $45-74$ years old), Soh and colleagues observed that marine omega 3 intake was associated with reduced risk of active MTB in a dosedependent manner [349]. Regarding amino acids and MTB infection, two RCTs were conducted, to the best of our knowledge, and published during the last 10 years. Ralph et al. studied the effect of $6 \mathrm{~g} /$ daily of L-arginine hydrochloride for 8 weeks in MTB clinical outcomes of 99 participants, but no effect was observed [350]. Schön et al. studied the effect of daily intake of arginine-supplemented foods (wheat crackers $0.1 \mathrm{~g}$ arginine $+30 \mathrm{~g}$ peanuts $1 \mathrm{~g}$ arginine) for 4 weeks in patients with smear positive pulmonary tuberculosis, with no observed effects on the outcomes addressed [351]. At this point, biologically relevant clinical studies are needed that take the insights of immune cell activation and differentiation into account.

\section{Immunonutrition as a form of host-directed therapy-ideation for future clinical possibilities}

The vastly expanding fields of personalized nutrition and immunometabolism deserve thorough clinical investigation to allow immunonutrition be part of clinical practice in precision immuno-oncology. A specialized clinical immunonutritionist, as a member of the medical care team, would be able to perform a complete evaluation of nutritional demands for each patient and to draft an immunonutrition scheme tailor-made for each individual. For example, the formulation of molecularly defined immunonutrition recipes - akin to "molecular gastronomy" but built on scientifically and medically sound bases-warrants testing in a patient-specific manner, representing a form of personalized host-directed therapy (HDT). There may also be patient groups who could benefit from a particular immunonutrition package, presenting "off-the-shelf" options. Also the routes and time schedule of administration of such 'immunonutrition' has to be considered. Patients may require a certain set of nutrients at a particular juncture and to be given via a particular route (more of one nutrient and less of another and administered in a specific anatomical location). These immunonutrition packages may also be considered at the same time as personalized cancer vaccines are being delivered (potentially with adjuvant-like properties) and/or during the monitoring phase, which may enhance the immune functions of $\mathrm{T}$ and $\mathrm{B}$ cells and partly compensate for nutrient despoiling by cancer cells [114]. Equally important are well-designed clinical trials evaluating the effect of immunonutrients on phenotypic changes of cells infiltrating the TME during immunotherapy. These can be pursued in translational studies as well as early-phase RCTs at suitable healthcare facilities.

\section{Novel concepts in long-term memory in protective immune responses and mitochondrial fitness}

TIL that resemble tissue resident memory T-cells are particularly effective against solid cancers as well as against pathogens. Immune checkpoint blockers target this distinct T-cell population [352]. This is of particular interest since pulmonary tissue resident T-cells (Trm) are abundant in the healthy lung and may play an important role in the first encounters of adaptive immune cells and pathogens invading into pulmonary tissue: T-cells that invade into the pulmonary tissue to form the granuloma could therefore stem from Trm, from regional lymph nodes or, not mutually exclusive, from peripheral blood. However, the phenotypes of Trm, i.e., $\mathrm{CD}^{+}$, CD69, $\mathrm{CD} 13^{+}$, are also shared by exhausted or activated TIL that express as well these markers [353], which makes it challenging to define what is a TIL and what a bona fide Trm. TIL as well as Trm have been studied in the context of cancer and chronic infections - and the key genes responsible for immune protection have been identified. TIL and Trm display both expression of transcription factors such as Hobit, Runx3 $\mathrm{f}$ and Bhlhe-40 [354, 355], with the latter factor promoting TIL and Trm functions and tissue persistence [354]. Bhlhe-40 favored Th1-type responses and was therefore found to be associated with IFN and granzyme B expression - conversely, Bhhe-40-deficient mice were shown to be inferior in containing melanoma or influenza infections [354]. TIL and Trem did not only share a similar phenotype but also the response and transcription pattern as compared to peripheral T-cells, described as "mitochondrial" fitness [356]. Mitochondria do 
not only provide energy via ATP but also shape the epigenome. Memory T-cells use oxidative phosphorylation (see above), a concept that was corroborated by the observation that skin Trm access fatty acids and fuel them into the tricarboxylic acid cycle (TCA); a feature that is again shared between Trm and TIL, but not by peripheral T-cells. Bhlhe- 40 is preferentially expressed in TCF-1 low cells (see below) that resemble rather Trm. This reflects an important biological function, it designates stem cell-like antigen-specific T-cells in the tissue, defined by strong TCF- 1 and low Tim 3 expression. These T-cells appear to respond to ICBs and give rise of PD1 high-positive cells that mediate immune protection [356, 357]. HDAC inhibitors, as well as acetate, have been shown to increase IFN- $\gamma$ production in TIL where Bhlhe 40 was downregulated [354] or in antigen-specific T-cells in an "immune exhaustion"-rich environment with high potassium [340]. Increased serum acetate, as a response to bacterial infection, is required for $\mathrm{CD}^{+} \mathrm{T}$-cell memory formation showing that exposure to pathogens does not only lead to immunopathology but also shapes biologically and clinically relevant antitarget-directed cellular immune responses [358].

Similarly to extrinsic factors, i.e., increased potassium in the tumor microenvironment, or increased serum acetate in infections, may shape the quality and quantity of cellular immune responses: Acetylation has been described in the context of histone modification, yet more detailed analysis, using modern proteomic methodologies, showed that other proteins, involved in cellular maintenance are also acetylated in cellular physiology and pathophysiology. This is mediated by enzymatic reactions, i.e., the transfer of an acetyl-group, and also occur via non-enzymatic reactions where acetyl-CoA plays a major role (reviewed in [359]). Acetyl-CoA, present in mitochondria as well as in the cytosol, is produced from a key enzyme in tumor cells, i.e., acetyl-CoA synthetase enzyme, ACSS2, and contributes to (tumor cell) proliferation. ACSS2, via the production of acetyl-CoA mediates the majority of acetate uptake into cells $[360,361]$ and presents an alternate mechanisms to provide acetate.

Mitochondrial stress and mitochondrial fitness versus " $\mathrm{mi}$ tochondrial health" has also been shown to play a biologically relevant role in TB and protective immune responses [362]. Type I interferons, i.e., IFN $\alpha$ and IFN $\beta$ are helpful to curb viral pathogens, yet they may be detrimental in MTB infections [363-365]. In contrast to type I interferons, IL-1 production has been shown to be protective in MTB, in part by limiting type I interferon production [366]. This dichotomy between type I interferon and IL-1 production may be dependent on the timing, whether the infection is newly acquired or chronic. Drug-induced, e.g., zileutin, reduction of IFN $\beta$ leads to less pro-inflammatory, negative effects of infections. The use of Zileutin has been explored as an adjunct therapy in addition to standard antibiotic treatments of patients with TB. IFN $\alpha$ and INF $\beta$ are produced during MTB infection dependent on (i) MTB access to the cytosol in hosT-cells and (ii) STING (stimulator of interferon' signaling) via mycobacterial DNA (mDNA) binding to the GMP-AMP synthase. A third mechanism has been described [362] where cGAS, a cytosolic DNA sensing structure that binds to dsDNA from stressed mitochondria, leads subsequently to IFN $\beta$ production [367]. This links the observation that Bhlh40 provides "mitochondrial health" and immune cell fitness with the notion that mitochondria are able to sense "danger" as well as to signal "danger" via the release of mitochondrial (mt) DNA and reactive oxygen radicals, which has been corroborated in other diseases, e.g., preclinical autoimmune diseases and viral-associated, type I interferon responses [368-370]. Thus, promoting "mitochondrial fitness" may help to curb non-productive inflammation, via downregulation of type I interferon(s) and to enhanced immune effector functions in antigen-specific tissues-resident T-cells and Trm. Rewiring immune responses by increasing mitochondrial health both in T-cells and (infected) macrophages is not only associated with mitochondrial functions but also with improved cellular metabolism [371]. For instance, MTB reduces glycolysis and the use of the TCA cycle along with oxidative phosphorylation in macrophages - with gradual differences between MTB and BCG. MTB reprograms macrophages to use exogenous fatty acids as compared to endogenous. MTB infection leads to reduced mitochondrial dependence on glucose and to increased use of fatty acids. Thus, acetate and HDAC inhibitors, which have been shown to "reprogram" mitochondria (in TIL and Trm), impact on MTB-associated effects on the mitochondrial competence in macrophages to produce reactive oxygen radicals and oxidizing fatty acids, glutamine, and glucose. The MTB-imprinted microenvironment is reminiscent of the tumor microenvironment that is characterized by "functional starvation," defined by increased potassium, altered mitochondrial metabolism, depletion of acetyl-coenzyme A $(\mathrm{CoA})$ and methionine intermediates, thereby limiting histone acetylation and the possibility of epigenetic programming and inducing effector molecules and T-cell differentiation [340]. Increased potassium in the (extracellular) space, most likely derived from necrotic cells [341], resulted in a "starvation" program of immune cells associated with increased TCF-1 expression, increased autophagy, and decreased nucleocytosolic acetyl-coenzyme A (AcCoA). That provides stronger persistence of (potentially anti-target-directed) Tcells in TIL or granuloma-associated lymphocytes (GAL) [372] which are associated with stemness, reminiscent of the recent observation that MTB granuloma lesions obtained from a non-human primate model of TB did not exhibit strong expression of immune exhaustion [373]. Thus, there may be similarities between the TME and MTB granuloma lesions, i.e., that hypoxia, necrosis, subsequent high potassium, and a particularly nutrient pattern impose a starvation program facilitating immune cell stemness. A better understanding of 
these intricate pathway may help to individually map the patients "immune situation" and guide therapeutic options to eradicate or to contain the pathogen (or transformed cells), while preserving long-term memory and avoid overt tissue damage by non-productive inflammation.

\section{Conclusions}

Modulating the immune system using nutrient supply may benefit future treatment regimens for patients with cancer or infections at healthcare centers. In addition, ongoing clinical trials evaluating vaccine and drug efficacy may also consider including molecularly defined nutrients and the microbiome as part of their monitoring schemes. The same applies to studies on the microbiome and host directed therapies. Clinical responses in patients with cancer or infections may be improved if 'holistic' treatment modalities, include immmunonutrition and consider the patients unique genetic and immunological background.

Acknowledgements Prof Giuseppe Ippolito, and Sir Prof Alimuddin Zumla are members of the Pan-African Network on Emerging and Reemerging Infections (PANDORA-ID-NET), funded by the European \& Developing Countries Clinical Trials Partnership, supported under Horizon 2020. Sir Zumla is in receipt of a National Institutes of Health Research senior investigator award. Prof Maeurer acknowledges support from and is funded by the Champalimaud Foundation. Prof Ippolito acknowledges support from the Italian Ministry of Health (Ricerca Corrente Linea 1)

Author contributions All authors conceptualized and reviewed all available data and clinical trials. RR and MM wrote the first draft. All authors finalized the review.

\section{Compliance with ethical standards}

Conflict of interest All authors are members of THE GLOBAL ALLIANCE BETWEEN CLINICAL CANCER AND INFECTIOUS DISEASE RESEARCH with a particular focus on the COVID-19 pandemic, to better understand the nature of COVID-19 pathophysiology and to take forward host-directed therapies. (Website: https://fchampalimaud. org/covid19/aci/).

\section{References}

1. Emambokus N, Granger A, Mott R, Helenius T (2017) The immunometabolism choreography. Cell Metab 26(1):1. https:// doi.org/10.1016/j.cmet.2017.06.020

2. Pearce EJ, Pearce EL (2017) Immunometabolism in 2017: driving immunity: all roads lead to metabolism. Nat Rev Immunol. https:// doi.org/10.1038/nri.2017.139

3. Mathis D, Shoelson SE (2011) Immunometabolism: an emerging frontier. Nat Rev Immunol 11(2):81. https://doi.org/10.1038/ nri2922
4. O’Neill LA, Kishton RJ, Rathmell J (2016) A guide to immunometabolism for immunologists. Nat Rev Immunol 16(9):553-565. https://doi.org/10.1038/nri.2016.70

5. O'Neill L (2017) Immunometabolism and the land of milk and honey. Nat Rev Immunol 17(4):217. https://oi.org/10.1038/nri. 2017.22

6. Loftus RM, Finlay DK (2016) Immunometabolism: cellular metabolism turns immune regulator. J Biol Chem 291(1):1-10. https://doi.org/10.1074/jbc.R115.693903

7. Kelly B, O'Neill LA (2015) Metabolic reprogramming in macrophages and dendritic cells in innate immunity. Cell Res 25(7): 771-784. https://doi.org/10.1038/cr.2015.68

8. Cao Y, Rathmell JC, Macintyre AN (2014) Metabolic reprogramming towards aerobic glycolysis correlates with greater proliferative ability and resistance to metabolic inhibition in CD8 versus CD4 T cells. PLoS One 9(8):e104104. https://doi.org/10. 1371/journal.pone.0104104

9. Rosa Neto JC, Lira FS, Roy S, Festuccia W (2017) Immunometabolism: molecular mechanisms, diseases, and therapies 2016. Mediat Inflamm 2017:8230298. https://doi.org/10. $1155 / 2017 / 8230298$

10. Schertzer JD, Steinberg GR (2014) Immunometabolism: the interface of immune and metabolic responses in disease. Immunol Cell Biol 92(4):303. https://doi.org/10.1038/icb.2014.12

11. Leech JM, Dhariwala MO, Lowe MM, Chu K, Merana GR, Cornuot C, Weckel A, Ma JM, Leitner EG, Gonzalez JR, Vasquez KS, Diep BA, Scharschmidt TC (2019) Toxintriggered interleukin-1 receptor signaling enables early-life discrimination of pathogenic versus commensal skin bacteria. Cell Host Microbe 26(6):795-809 e795. https://doi.org/10.1016/j. chom.2019.10.007

12. Rood JE, Stuart T, Ghazanfar S, Biancalani T, Fisher E, Butler A, Hupalowska A, Gaffney L, Mauck W, Eraslan G, Marioni JC, Regev A, Satija R (2019) Toward a common coordinate framework for the human body. Cell 179(7):1455-1467. https://doi.org/ 10.1016/j.cell.2019.11.019

13. Pearce EL, Pearce EJ (2013) Metabolic pathways in immune cell activation and quiescence. Immunity 38(4):633-643. https://doi. org/10.1016/j.immuni.2013.04.005

14. Norata GD, Caligiuri G, Chavakis T, Matarese G, Netea MG, Nicoletti A, O'Neill LA, Marelli-Berg FM (2015) The cellular and molecular basis of translational immunometabolism. Immunity 43(3):421-434. https://doi.org/10.1016/j.immuni. 2015.08.023

15. Puleston DJ, Villa M, Pearce EL (2017) Ancillary activity: beyond core metabolism in immune cells. Cell Metab 26(1):131-141. https://doi.org/10.1016/j.cmet.2017.06.019

16. Prochnicki T, Latz E (2017) Inflammasomes on the crossroads of innate immune recognition and metabolic control. Cell Metab 26(1):71-93. https://doi.org/10.1016/j.cmet.2017.06.018

17. Pearce EL, Walsh MC, Cejas PJ, Harms GM, Shen H, Wang LS, Jones RG, Choi Y (2009) Enhancing CD8 T-cell memory by modulating fatty acid metabolism. Nature 460(7251):103-107. https://doi.org/10.1038/nature08097

18. van der Windt GJ, Everts B, Chang CH, Curtis JD, Freitas TC, Amiel E, Pearce EJ, Pearce EL (2012) Mitochondrial respiratory capacity is a critical regulator of CD8+ T cell memory development. Immunity 36(1):68-78. https://doi.org/10.1016/j.immuni. 2011.12.007

19. O'Sullivan D, van der Windt GJ, Huang SC, Curtis JD, Chang CH, Buck MD, Qiu J, Smith AM, Lam WY, DiPlato LM, Hsu FF, Birnbaum MJ, Pearce EJ, Pearce EL (2014) Memory CD8(+) T cells use cell-intrinsic lipolysis to support the metabolic programming necessary for development. Immunity 41(1):75-88. https:// doi.org/10.1016/j.immuni.2014.06.005 
20. Lochner M, Berod L, Sparwasser T (2015) Fatty acid metabolism in the regulation of $\mathrm{T}$ cell function. Trends Immunol 36(2):81-91. https://doi.org/10.1016/j.it.2014.12.005

21. Pan Y, Tian T, Park CO, Lofftus SY, Mei S, Liu X, Luo C, O’Malley JT, Gehad A, Teague JE, Divito SJ, Fuhlbrigge R, Puigserver P, Krueger JG, Hotamisligil GS, Clark RA, Kupper TS (2017) Survival of tissue-resident memory T cells requires exogenous lipid uptake and metabolism. Nature 543(7644):252256. https://doi.org/10.1038/nature21379

22. Raud B, Roy DG, Divakaruni AS, Tarasenko TN, Franke R, Ma EH, Samborska B, Hsieh WY, Wong AH, Stuve P, ArnoldSchrauf C, Guderian M, Lochner M, Rampertaap S, Romito K, Monsale J, Bronstrup M, Bensinger SJ, Murphy AN, McGuire PJ, Jones RG, Sparwasser T, Berod L (2018) Etomoxir actions on regulatory and memory $\mathrm{T}$ cells are independent of Cpt1amediated fatty acid oxidation. Cell Metab 28(3):504-515.e507. https://doi.org/10.1016/j.cmet.2018.06.002

23. Mills EL, O'Neill LA (2016) Reprogramming mitochondrial metabolism in macrophages as an anti-inflammatory signal. Eur J Immunol 46(1):13-21. https://doi.org/10.1002/eji.201445427

24. Zhang L, Romero P (2018) Metabolic control of CD8(+) T cell fate decisions and antitumor immunity. Trends Mol Med 24(1): 30-48. https://doi.org/10.1016/j.molmed.2017.11.005

25. Chen DS, Mellman I (2013) Oncology meets immunology: the cancer-immunity cycle. Immunity 39(1):1-10. https://doi.org/10. 1016/j.immuni.2013.07.012

26. Andrejeva G, Rathmell JC (2017) Similarities and distinctions of cancer and immune metabolism in inflammation and tumors. Cell Metab 26(1):49-70. https://doi.org/10.1016/j.cmet.2017.06.004

27. Cohen R, Neuzillet C, Tijeras-Raballand A, Faivre S, de Gramont A, Raymond E (2015) Targeting cancer cell metabolism in pancreatic adenocarcinoma. Oncotarget 6(19):16832-16847. https:// doi.org/10.18632/oncotarget.4160

28. Arsenault RJ, Kogut MH (2015) Immunometabolism and the kinome peptide array: a new perspective and tool for the study of gut health. Front Vet Sci 2:44. https://doi.org/10.3389/fvets. 2015.00044

29. McPhee JB, Schertzer JD (2015) Immunometabolism of obesity and diabetes: microbiota link compartmentalized immunity in the gut to metabolic tissue inflammation. Clin Sci (Lond) 129(12): 1083-1096. https://doi.org/10.1042/cs20150431

30. Ponton F, Wilson K, Cotter SC, Raubenheimer D, Simpson SJ (2011) Nutritional immunology: a multi-dimensional approach. PLoS Pathog 7(12):e1002223. https://doi.org/10.1371/journal. ppat.1002223

31. Zapatera B, Prados A, Gomez-Martinez S, Marcos A (2015) Immunonutrition: methodology and applications. Nutr Hosp 31(Suppl 3):145-154. https://doi.org/10.3305/nh.2015.31.sup3. 8762

32. Cheng SC, Quintin J, Cramer RA, Shepardson KM, Saeed S, Kumar V, Giamarellos-Bourboulis EJ, Martens JH, Rao NA, Aghajanirefah A, Manjeri GR, Li Y, Ifrim DC, Arts RJ, van der Veer BM, Deen PM, Logie C, O'Neill LA, Willems P, van de Veerdonk FL, van der Meer JW, Ng A, Joosten LA, Wijmenga C, Stunnenberg HG, Xavier RJ, Netea MG (2014) mTOR- and HIF1alpha-mediated aerobic glycolysis as metabolic basis for trained immunity. Science 345(6204):1250684. https://doi.org/10.1126/ science. 1250684

33. Palsson-McDermott EM, O'Neill LA (2013) The Warburg effect then and now: from cancer to inflammatory diseases. Bioessays 35(11):965-973. https://doi.org/10.1002/bies.201300084

34. Fadaka A, Ajiboye B, Ojo O, Adewale O, Olayide I, Emuowhochere R (2017) Biology of glucose metabolization in cancer cells. J Oncol Sci 3(2):45-51. https://doi.org/10.1016/j. jons.2017.06.002
35. Jiang B (2017) Aerobic glycolysis and high level of lactate in cancer metabolism and microenvironment. Genes Dis 4(1):2527. https://doi.org/10.1016/j.gendis.2017.02.003

36. Liao Y (2017) Cancer metabolism as we know it today: a prologue to a special issue of cancer metabolism. Genes Dis 4(1):4-6. https://doi.org/10.1016/j.gendis.2017.02.001

37. Tan Z, Xie N, Cui H, Moellering DR, Abraham E, Thannickal VJ, Liu G (2015) Pyruvate dehydrogenase kinase 1 participates in macrophage polarization via regulating glucose metabolism. J Immunol 194(12):6082-6089. https://doi.org/10.4049/jimmunol. 1402469

38. Palsson-McDermott EM, Curtis AM, Goel G, Lauterbach MA, Sheedy FJ, Gleeson LE, van den Bosch MW, Quinn SR, Domingo-Fernandez R, Johnston DG, Jiang JK, Israelsen WJ, Keane J, Thomas C, Clish C, Vander Heiden M, Xavier RJ, O'Neill LA (2015) Pyruvate kinase M2 regulates Hif-1alpha activity and IL-1beta induction and is a critical determinant of the Warburg effect in LPS-activated macrophages. Cell Metab 21(1): 65-80. https://doi.org/10.1016/j.cmet.2014.12.005

39. Shapiro H, Lutaty A, Ariel A (2011) Macrophages, meta-inflammation, and immuno-metabolism. ScientificWorldJournal 11: 2509-2529. https://doi.org/10.1100/2011/397971

40. Curi R, de Siqueira MR, de Campos Crispin LA, Norata GD, Sampaio SC, Newsholme P (2017) A past and present overview of macrophage metabolism and functional outcomes. Clin Sci (Lond) 131(12):1329-1342. https://doi.org/10.1042/cs20170220

41. Ryan DG, O'Neill LAJ (2017) Krebs cycle rewired for macrophage and dendritic cell effector functions. FEBS Lett 591(19): 2992-3006. https://doi.org/10.1002/1873-3468.12744

42. Almeida L, Lochner M, Berod L, Sparwasser T (2016) Metabolic pathways in $\mathrm{T}$ cell activation and lineage differentiation. Semin Immunol 28(5):514-524. https://doi.org/10.1016/j.smim.2016.10. 009

43. Stincone A, Prigione A, Cramer T, Wamelink MM, Campbell K, Cheung E, Olin-Sandoval V, Gruning NM, Kruger A, Tauqeer Alam M, Keller MA, Breitenbach M, Brindle KM, Rabinowitz JD, Ralser M (2015) The return of metabolism: biochemistry and physiology of the pentose phosphate pathway. Biol Rev Camb Philos Soc 90(3):927-963. https://doi.org/10.1111/brv.12140

44. Barcia-Vieitez R, Ramos-Martinez JI (2014) The regulation of the oxidative phase of the pentose phosphate pathway: new answers to old problems. IUBMB Life 66(11):775-779. https://doi.org/10. 1002/iub.1329

45. Nagy C, Haschemi A (2015) Time and demand are two critical dimensions of immunometabolism: the process of macrophage activation and the pentose phosphate pathway. Front Immunol 6: 164. https://doi.org/10.3389/fimmu.2015.00164

46. Akram M (2014) Citric acid cycle and role of its intermediates in metabolism. Cell Biochem Biophys 68(3):475-478. https://doi. org/10.1007/s12013-013-9750-1

47. Berod L, Friedrich C, Nandan A, Freitag J, Hagemann S, Harmrolfs K, Sandouk A, Hesse C, Castro CN, Bahre H, Tschirner SK, Gorinski N, Gohmert M, Mayer CT, Huehn J, Ponimaskin E, Abraham WR, Muller R, Lochner M, Sparwasser $\mathrm{T}$ (2014) De novo fatty acid synthesis controls the fate between regulatory T and T helper 17 cells. Nat Med 20(11):1327-1333. https://doi.org/10.1038/nm.3704

48. Alvarez-Curto E, Milligan G (2016) Metabolism meets immunity: the role of free fatty acid receptors in the immune system. Biochem Pharmacol 114:3-13. https://doi.org/10.1016/j.bcp. 2016.03.017

49. Namgaladze D, Brune B (2016) Macrophage fatty acid oxidation and its roles in macrophage polarization and fatty acid-induced inflammation. Biochim Biophys Acta 1861(11):1796-1807. https://doi.org/10.1016/j.bbalip.2016.09.002 
50. Holecek M, Vodenicarovova M, Siman P (2017) Acute effects of phenylbutyrate on glutamine, branched-chain amino acid and protein metabolism in skeletal muscles of rats. Int J Exp Pathol 98(3): 127-133. https://doi.org/10.1111/iep.12231

51. Cruzat V, Macedo Rogero M, Noel Keane K, Curi R, Newsholme P (2018) Glutamine: metabolism and immune function, supplementation and clinical translation. Nutrients 10(11). https://doi. org/10.3390/nu10111564

52. Ren W, Wang K, Yin J, Chen S, Liu G, Tan B, Wu G, Bazer FW, Peng Y, Yin Y (2016) Glutamine-induced secretion of intestinal secretory immunoglobulin A: a mechanistic perspective. Front Immunol 7:503. https://doi.org/10.3389/fimmu.2016.00503

53. Sartori T, Galvao Dos Santos G, Nogueira-Pedro A, Makiyama E, Rogero MM, Borelli P, Fock RA (2018) Effects of glutamine, taurine and their association on inflammatory pathway markers in macrophages. Inflammopharmacology 26(3):829-838. https:// doi.org/10.1007/s10787-017-0406-4

54. Moinard C, Caldefie-Chezet F, Walrand S, Vasson MP, Cynober L (2002) Evidence that glutamine modulates respiratory burst in stressed rat polymorphonuclear cells through its metabolism into arginine. Br J Nutr 88(6):689-695. https://doi.org/10.1079/ bjn2002724

55. Carr EL, Kelman A, Wu GS, Gopaul R, Senkevitch E, Aghvanyan A, Turay AM, Frauwirth KA (2010) Glutamine uptake and metabolism are coordinately regulated by ERK/MAPK during T lymphocyte activation. J Immunol 185(2):1037-1044. https://doi.org/ 10.4049/jimmunol.0903586

56. Kim SH, Roszik J, Grimm EA, Ekmekcioglu S (2018) Impact of L-arginine metabolism on immune response and anticancer immunotherapy. Front Oncol 8:67. https://doi.org/10.3389/fonc.2018. 00067

57. Geiger R, Rieckmann JC, Wolf T, Basso C, Feng Y, Fuhrer T, Kogadeeva M, Picotti P, Meissner F, Mann M, Zamboni N, Sallusto F, Lanzavecchia A (2016) L-Arginine modulates T cell metabolism and enhances survival and anti-tumor activity. Cell 167(3):829-842.e813. https://doi.org/10.1016/j.cell.2016.09.031

58. Duque-Correa MA, Kuhl AA, Rodriguez PC, Zedler U, Schommer-Leitner S, Rao M, Weiner J 3rd, Hurwitz R, Qualls JE, Kosmiadi GA, Murray PJ, Kaufmann SH, Reece ST (2014) Macrophage arginase-1 controls bacterial growth and pathology in hypoxic tuberculosis granulomas. Proc Natl Acad Sci U S A 111 (38):E4024-E4032. https://doi.org/10.1073/pnas. 1408839111

59. Rodriguez PC, Ochoa AC, Al-Khami AA (2017) Arginine metabolism in myeloid cells shapes innate and adaptive immunity. Front Immunol 8:93. https://doi.org/10.3389/fimmu.2017.00093

60. Rodriguez PC, Zea AH, Culotta KS, Zabaleta J, Ochoa JB, Ochoa AC (2002) Regulation of T cell receptor CD3zeta chain expression by L-arginine. J Biol Chem 277(24):21123-21129. https:// doi.org/10.1074/jbc.M110675200

61. Korrer MJ, Zhang Y, Routes JM (2014) Possible role of arginase1 in concomitant tumor immunity. PLoS One 9(3):e91370. https:// doi.org/10.1371/journal.pone.0091370

62. Saligan LN, Lukkahatai N, Zhang ZJ, Cheung CW, Wang XM (2018) Altered Cd8+ T lymphocyte response triggered by arginase 1: implication for fatigue intensification during localized radiation therapy in prostate cancer patients. Neuropsychiatry 8(4):1249 1262. https://doi.org/10.4172/Neuropsychiatry.1000454

63. Rodriguez PC, Ochoa AC (2008) Arginine regulation by myeloid derived suppressor cells and tolerance in cancer: mechanisms and therapeutic perspectives. Immunol Rev 222:180-191. https://doi. org/10.1111/j.1600-065X.2008.00608.x

64. Raber P, Ochoa AC, Rodriguez PC (2012) Metabolism of Larginine by myeloid-derived suppressor cells in cancer: mechanisms of $\mathrm{T}$ cell suppression and therapeutic perspectives.
Immunol Investig 41(6-7):614-634. https://doi.org/10.3109/ 08820139.2012 .680634

65. Wu H, Gong J, Liu Y (2018) Indoleamine 2, 3-dioxygenase regulation of immune response (review). Mol Med Rep 17(4):48674873. https://doi.org/10.3892/mmr.2018.8537

66. Brochez L, Chevolet I, Kruse V (2017) The rationale of indoleamine 2,3-dioxygenase inhibition for cancer therapy. Eur J Cancer 76:167-182. https://doi.org/10.1016/j.ejca.2017.01.011

67. Wang XF, Wang HS, Wang H, Zhang F, Wang KF, Guo Q, Zhang G, Cai SH, Du J (2014) The role of indoleamine 2,3dioxygenase (IDO) in immune tolerance: focus on macrophage polarization of THP-1 cells. Cell Immunol 289(1-2):42-48. https://doi.org/10.1016/j.cellimm.2014.02.005

68. Husain Z, Huang Y, Seth P, Sukhatme VP (2013) Tumor-derived lactate modifies antitumor immune response: effect on myeloidderived suppressor cells and NK cells. J Immunol 191(3):14861495. https://doi.org/10.4049/jimmunol.1202702

69. Hirschhaeuser F, Sattler UG, Mueller-Klieser W (2011) Lactate: a metabolic key player in cancer. Cancer Res 71(22):6921-6925. https://doi.org/10.1158/0008-5472.can-11-1457

70. Haas R, Smith J, Rocher-Ros V, Nadkarni S, Montero-Melendez T, D'Acquisto F, Bland EJ, Bombardieri M, Pitzalis C, Perretti M, Marelli-Berg FM, Mauro C (2015) Lactate regulates metabolic and pro-inflammatory circuits in control of $\mathrm{T}$ cell migration and effector functions. PLoS Biol 13(7):e1002202. https://doi.org/10. 1371/journal.pbio.1002202

71. Vander Heiden MG, Cantley LC, Thompson CB (2009) Understanding the Warburg effect: the metabolic requirements of cell proliferation. Science 324(5930):1029-1033. https://doi. org/10.1126/science.1160809

72. Vazquez A, Liu J, Zhou Y, Oltvai ZN (2010) Catabolic efficiency of aerobic glycolysis: the Warburg effect revisited. BMC Syst Biol 4:58. https://doi.org/10.1186/1752-0509-4-58

73. Jha AK, Huang SC, Sergushichev A, Lampropoulou V, Ivanova Y, Loginicheva E, Chmielewski K, Stewart KM, Ashall J, Everts B, Pearce EJ, Driggers EM, Artyomov MN (2015) Network integration of parallel metabolic and transcriptional data reveals metabolic modules that regulate macrophage polarization. Immunity 42(3):419-430. https://doi.org/10.1016/j.immuni.2015.02.005

74. Epstein T, Gatenby RA, Brown JS (2017) The Warburg effect as an adaptation of cancer cells to rapid fluctuations in energy demand. PLoS One 12(9):e0185085. https://doi.org/10.1371/ journal.pone. 0185085

75. Lu J, Tan M, Cai Q (2015) The Warburg effect in tumor progression: mitochondrial oxidative metabolism as an anti-metastasis mechanism. Cancer Lett 356(2 Pt A):156-164. https://doi.org/ 10.1016/j.canlet.2014.04.001

76. Zhu L, Zhao Q, Yang T, Ding W, Zhao Y (2015) Cellular metabolism and macrophage functional polarization. Int Rev Immunol 34(1):82-100. https://doi.org/10.3109/08830185.2014.969421

77. Van den Bossche J, O’Neill LA, Menon D (2017) Macrophage immunometabolism: where are we (going)? Trends Immunol 38(6):395-406. https://doi.org/10.1016/j.it.2017.03.001

78. Torres A, Makowski L, Wellen KE (2016) Immunometabolism: metabolism fine-tunes macrophage activation. Elife 5. https://doi. org/10.7554/eLife.14354

79. Diskin C, Palsson-McDermott EM (2018) Metabolic modulation in macrophage effector function. Front Immunol 9:270. https:// doi.org/10.3389/fimmu.2018.00270

80. Zhou D, Huang C, Lin Z, Zhan S, Kong L, Fang C, Li J (2014) Macrophage polarization and function with emphasis on the evolving roles of coordinated regulation of cellular signaling pathways. Cell Signal 26(2):192-197. https://doi.org/10.1016/j. cellsig.2013.11.004 
81. Artyomov MN, Sergushichev A, Schilling JD (2016) Integrating immunometabolism and macrophage diversity. Semin Immunol 28(5):417-424. https://doi.org/10.1016/j.smim.2016.10.004

82. Biswas SK, Mantovani A (2012) Orchestration of metabolism by macrophages. Cell Metab 15(4):432-437. https://doi.org/10.1016/ j.cmet.2011.11.013

83. Bosca L, Gonzalez-Ramos S, Prieto P, Fernandez-Velasco M, Mojena M, Martin-Sanz P, Alemany S (2015) Metabolic signatures linked to macrophage polarization: from glucose metabolism to oxidative phosphorylation. Biochem Soc Trans 43(4):740-744. https://doi.org/10.1042/bst20150107

84. O'Neill LA (2015) A broken Krebs cycle in macrophages. Immunity 42(3):393-394. https://doi.org/10.1016/j.immuni.2015.02.017

85. Lirk P, Hoffmann G, Rieder J (2002) Inducible nitric oxide synthase - time for reappraisal. Curr Drug Targets Inflamm Allergy 1(1):89-108

86. Rath M, Muller I, Kropf P, Closs EI, Munder M (2014) Metabolism via arginase or nitric oxide synthase: two competing arginine pathways in macrophages. Front Immunol 5:532. https:// doi.org/10.3389/fimmu.2014.00532

87. Starling S (2017) Immunometabolism: T cells activate the fear. Nat Rev Immunol 17(12):730-731. https://doi.org/10.1038/nri.2017.126

88. MacIver NJ, Michalek RD, Rathmell JC (2013) Metabolic regulation of T lymphocytes. Annu Rev Immunol 31:259-283. https:// doi.org/10.1146/annurev-immunol-032712-095956

89. Chen H, Yang T, Zhu L, Zhao Y (2015) Cellular metabolism on T-cell development and function. Int Rev Immunol 34(1):19-33. https://doi.org/10.3109/08830185.2014.902452

90. Waickman AT, Powell JD (2012) mTOR, metabolism, and the regulation of T-cell differentiation and function. Immunol Rev 249(1):43-58. https://doi.org/10.1111/j.1600-065X.2012.01152.x

91. Shi LZ, Wang R, Huang G, Vogel P, Neale G, Green DR, Chi H (2011) HIF1alpha-dependent glycolytic pathway orchestrates a metabolic checkpoint for the differentiation of TH17 and Treg cells. J Exp Med 208(7):1367-1376. https://doi.org/10.1084/jem. 20110278

92. Bayes HK, Ritchie ND, Evans TJ (2016) Interleukin-17 is required for control of chronic lung infection caused by Pseudomonas aeruginosa. Infect Immun 84(12):3507-3516. https://doi.org/10.1128/iai.00717-16

93. Gopal R, Monin L, Slight S, Uche U, Blanchard E, Fallert Junecko BA, Ramos-Payan R, Stallings CL, Reinhart TA, Kolls JK, Kaushal D, Nagarajan U, Rangel-Moreno J, Khader SA (2014) Unexpected role for IL-17 in protective immunity against hypervirulent Mycobacterium tuberculosis HN878 infection. PLoS Pathog 10(5):e1004099. https://doi.org/10.1371/journal.ppat. 1004099

94. Lereclus E, Tout M, Girault A, Baroukh N, Caulet M, Borg C, Bouche O, Ternant D, Paintaud G, Lecomte T, Raoul W (2017) A possible association of baseline serum IL-17A concentrations with progression-free survival of metastatic colorectal cancer patients treated with a bevacizumab-based regimen. BMC Cancer 17(1): 220. https://doi.org/10.1186/s12885-017-3210-z

95. Fabre JAS, Giustinniani J, Garbar C, Merrouche Y, Antonicelli F, Bensussan A (2018) The interleukin-17 family of cytokines in breast cancer. Int J Mol Sci 19(12). https://doi.org/10.3390/ ijms 19123880

96. Doughty CA, Bleiman BF, Wagner DJ, Dufort FJ, Mataraza JM, Roberts MF, Chiles TC (2006) Antigen receptor-mediated changes in glucose metabolism in B lymphocytes: role of phosphatidylinositol 3-kinase signaling in the glycolytic control of growth. Blood 107(11):4458-4465. https://doi.org/10.1182/ blood-2005-12-4788

97. Caro-Maldonado A, Wang R, Nichols AG, Kuraoka M, Milasta S, Sun LD, Gavin AL, Abel ED, Kelsoe G, Green DR, Rathmell JC (2014) Metabolic reprogramming is required for antibody production that is suppressed in anergic but exaggerated in chronically BAFF-exposed B cells. J Immunol 192(8):3626-3636. https://doi.org/10.4049/jimmunol.1302062

98. O'Neill LA, Pearce EJ (2016) Immunometabolism governs dendritic cell and macrophage function. J Exp Med 213(1):15-23. https://doi.org/10.1084/jem.20151570

99. Al-Khami AA, Rodriguez PC, Ochoa AC (2017) Energy metabolic pathways control the fate and function of myeloid immune cells. J Leukoc Biol 102(2):369-380. https://doi.org/10.1189/jlb. 1VMR1216-535R

100. Pearce EJ, Everts B (2015) Dendritic cell metabolism. Nat Rev Immunol 15(1):18-29. https://doi.org/10.1038/nri3771

101. Jantsch J, Chakravortty D, Turza N, Prechtel AT, Buchholz B, Gerlach RG, Volke M, Glasner J, Warnecke C, Wiesener MS, Eckardt KU, Steinkasserer A, Hensel M, Willam C (2008) Hypoxia and hypoxia-inducible factor- 1 alpha modulate lipopolysaccharide-induced dendritic cell activation and function. J Immunol 180(7):4697-4705. https://doi.org/10.4049/jimmunol. 180.7.4697

102. Krawczyk CM, Holowka T, Sun J, Blagih J, Amiel E, DeBerardinis RJ, Cross JR, Jung E, Thompson CB, Jones RG, Pearce EJ (2010) Toll-like receptor-induced changes in glycolytic metabolism regulate dendritic cell activation. Blood 115(23): 4742-4749. https://doi.org/10.1182/blood-2009-10-249540

103. Sim WJ, Ahl PJ, Connolly JE (2016) Metabolism is central to tolerogenic dendritic cell function. Mediat Inflamm 2016: 2636701. https://doi.org/10.1155/2016/2636701

104. Everts B, Amiel E, Huang SC, Smith AM, Chang CH, Lam WY, Redmann V, Freitas TC, Blagih J, van der Windt GJ, Artyomov MN, Jones RG, Pearce EL, Pearce EJ (2014) TLR-driven early glycolytic reprogramming via the kinases TBK1-IKKvarepsilon supports the anabolic demands of dendritic cell activation. Nat Immunol 15(4):323-332. https://doi.org/10.1038/ni.2833

105. Pantel A, Teixeira A, Haddad E, Wood EG, Steinman RM, Longhi MP (2014) Direct type I IFN but not MDA5/TLR3 activation of dendritic cells is required for maturation and metabolic shift to glycolysis after poly IC stimulation. PLoS Biol 12(1): e1001759. https://doi.org/10.1371/journal.pbio.1001759

106. Thwe PM, Amiel E (2018) The role of nitric oxide in metabolic regulation of dendritic cell immune function. Cancer Lett 412: 236-242. https://doi.org/10.1016/j.canlet.2017.10.032

107. Mondanelli G, Bianchi R, Pallotta MT, Orabona C, Albini E, Iacono A, Belladonna ML, Vacca C, Fallarino F, Macchiarulo A, Ugel S, Bronte V, Gevi F, Zolla L, Verhaar A, Peppelenbosch M, Mazza EMC, Bicciato S, Laouar Y, Santambrogio L, Puccetti P, Volpi C, Grohmann U (2017) A relay pathway between arginine and tryptophan metabolism confers immunosuppressive properties on dendritic cells. Immunity 46(2):233-244. https://doi.org/10.1016/j.immuni.2017.01.005

108. Kedia-Mehta N, Finlay DK (2019) Competition for nutrients and its role in controlling immune responses. Nat Commun 10(1): 2123. https://doi.org/10.1038/s41467-019-10015-4

109. Cascone T, McKenzie JA, Mbofung RM, Punt S, Wang Z, Xu C, Williams LJ, Wang Z, Bristow CA, Carugo A, Peoples MD, Li L, Karpinets T, Huang L, Malu S, Creasy C, Leahey SE, Chen J, Chen Y, Pelicano H, Bernatchez C, Gopal YNV, Heffernan TP, Hu J, Wang J, Amaria RN, Garraway LA, Huang P, Yang P, Wistuba II, Woodman SE, Roszik J, Davis RE, Davies MA, Heymach JV, Hwu P, Peng W (2018) Increased tumor glycolysis characterizes immune resistance to adoptive T cell therapy. Cell Metab 27(5):977-987.e974. https://doi.org/10.1016/j.cmet.2018.02.024

110. Bowden SD, Rowley G, Hinton JC, Thompson A (2009) Glucose and glycolysis are required for the successful infection of macrophages and mice by Salmonella enterica serovar Typhimurium. Infect Immun 77(7):3117-3126. https://doi.org/10.1128/iai.00093-09 
111. Thai M, Thaker SK, Feng J, Du Y, Hu H, Ting Wu T, Graeber TG, Braas D, Christofk HR (2015) MYC-induced reprogramming of glutamine catabolism supports optimal virus replication. Nat Commun 6:8873. https://doi.org/10.1038/ncomms9873

112. Courtnay R, Ngo DC, Malik N, Ververis K, Tortorella SM, Karagiannis TC (2015) Cancer metabolism and the Warburg effect: the role of HIF-1 and PI3K. Mol Biol Rep 42(4):841-851. https://doi.org/10.1007/s11033-015-3858-x

113. Dang CV, Kim JW (2018) Convergence of cancer metabolism and immunity: an overview. Biomol Ther 26(1):4-9. https://doi.org/ 10.4062/biomolther.2017.194

114. Renner K, Singer K, Koehl GE, Geissler EK, Peter K, Siska PJ, Kreutz M (2017) Metabolic hallmarks of tumor and immune cells in the tumor microenvironment. Front Immunol 8:248. https://doi. org/10.3389/fimmu.2017.00248

115. Warburg O, Wind F, Negelein E (1927) The metabolism of tumors in the body. J Gen Physiol 8(6):519-530. https://doi.org/10.1085/ jgp.8.6.519

116. Koppenol WH, Bounds PL, Dang CV (2011) Otto Warburg's contributions to current concepts of cancer metabolism. Nat Rev Cancer 11(5):325-337. https://doi.org/10.1038/nrc3038

117. Yun J, Rago C, Cheong I, Pagliarini R, Angenendt P, Rajagopalan H, Schmidt K, Willson JK, Markowitz S, Zhou S, Diaz LA Jr, Velculescu VE, Lengauer C, Kinzler KW, Vogelstein B, Papadopoulos N (2009) Glucose deprivation contributes to the development of KRAS pathway mutations in tumor cells. Science 325(5947):1555-1559. https://doi.org/10.1126/science.1174229

118. Lee N, Kim D (2016) Cancer metabolism: fueling more than just growth. Mol Cell 39(12):847-854. https://doi.org/10.14348/ molcells.2016.0310

119. Huang R, Zong X (2017) Aberrant cancer metabolism in epithelial-mesenchymal transition and cancer metastasis: mechanisms in cancer progression. Crit Rev Oncol Hematol 115:13-22. https://doi.org/10.1016/j.critrevonc.2017.04.005

120. Corbet C, Feron O (2017) Tumour acidosis: from the passenger to the driver's seat. Nat Rev Cancer 17(10):577-593. https://doi.org/ 10.1038/nrc.2017.77

121. Damaghi M, Tafreshi NK, Lloyd MC, Sprung R, Estrella V, Wojtkowiak JW, Morse DL, Koomen JM, Bui MM, Gatenby RA, Gillies RJ (2015) Chronic acidosis in the tumour microenvironment selects for overexpression of LAMP2 in the plasma membrane. Nat Commun 6:8752. https://doi.org/10.1038/ ncomms 9752

122. Luo F, Zou Z, Liu X, Ling M, Wang Q, Wang Q, Lu L, Shi L, Liu Y, Liu Q, Zhang A (2017) Enhanced glycolysis, regulated by HIF1alpha via MCT-4, promotes inflammation in arsenite-induced carcinogenesis. Carcinogenesis 38(6):615-626. https://doi.org/ 10.1093/carcin/bgx034

123. Lien S, Lowman HB (2008) Therapeutic anti-VEGF antibodies. Handb Exp Pharmacol 181:131-150. https://doi.org/10.1007/9783-540-73259-4 6

124. Ueda S, Saeki T, Osaki A, Yamane T, Kuji I (2017) Bevacizumab induces acute hypoxia and cancer progression in patients with refractory breast cancer: multimodal functional imaging and multiplex cytokine analysis. Clin Cancer Res 23(19):5769-5778. https://doi.org/10.1158/1078-0432.Ccr-17-0874

125. Cheong H (2015) Integrating autophagy and metabolism in cancer. Arch Pharm Res 38(3):358-371. https://doi.org/10.1007/ s12272-015-0562-2

126. Goldsmith J, Levine B, Debnath J (2014) Autophagy and cancer metabolism. Methods Enzymol 542:25-57. https://doi.org/10. 1016/b978-0-12-416618-9.00002-9

127. Brown RS, Wahl RL (1993) Overexpression of Glut-1 glucose transporter in human breast cancer. An immunohistochemical study. Cancer 72(10):2979-2985
128. Canpolat T, Ersoz C, Uguz A, Vardar MA, Altintas A (2016) GLUT-1 expression in proliferative endometrium, endometrial hyperplasia, endometrial adenocarcinoma and the relationship between GLUT-1 expression and prognostic parameters in endometrial adenocarcinoma. Turk Patoloji Derg 32(3):141-147. https:// doi.org/10.5146/tjpath.2015.01352

129. Cho H, Lee YS, Kim J, Chung JY, Kim JH (2013) Overexpression of glucose transporter-1 (GLUT-1) predicts poor prognosis in epithelial ovarian cancer. Cancer Investig 31(9):607-615. https://doi. org/10.3109/07357907.2013.849722

130. Li CX, Sun JL, Gong ZC, Lin ZQ, Liu H (2016) Prognostic value of GLUT-1 expression in oral squamous cell carcinoma: a prismacompliant meta-analysis. Medicine (Baltimore) 95(45):e5324. https://doi.org/10.1097/md.0000000000005324

131. Yang J, Wen J, Tian T, Lu Z, Wang Y, Wang Z, Wang X, Yang Y (2017) GLUT-1 overexpression as an unfavorable prognostic biomarker in patients with colorectal cancer. Oncotarget 8(7):1178811796. https://doi.org/10.18632/oncotarget.14352

132. Nagarajan A, Malvi P, Wajapeyee N (2016) Oncogene-directed alterations in cancer cell metabolism. Trends Cancer 2(7):365377. https://doi.org/10.1016/j.trecan.2016.06.002

133. Boros LG, Torday JS, Lim S, Bassilian S, Cascante M, Lee WN (2000) Transforming growth factor beta2 promotes glucose carbon incorporation into nucleic acid ribose through the nonoxidative pentose cycle in lung epithelial carcinoma cells. Cancer Res 60(5):1183-1185

134. Marchiq I, Pouyssegur J (2016) Hypoxia, cancer metabolism and the therapeutic benefit of targeting lactate/ $\mathrm{H}(+)$ symporters. J Mol Med 94(2):155-171. https://doi.org/10.1007/s00109-015-1307-x

135. Komohara Y, Takeya M (2017) CAFs and TAMs: maestros of the tumour microenvironment. J Pathol 241(3):313-315. https://doi. org/10.1002/path.4824

136. Hashimoto O, Yoshida M, Koma Y, Yanai T, Hasegawa D, Kosaka Y, Nishimura N, Yokozaki H (2016) Collaboration of cancer-associated fibroblasts and tumour-associated macrophages for neuroblastoma development. J Pathol 240(2):211-223. https:// doi.org/10.1002/path.4769

137. Zhang A, Qian Y, Ye Z, Chen H, Xie H, Zhou L, Shen Y, Zheng S (2017) Cancer-associated fibroblasts promote M2 polarization of macrophages in pancreatic ductal adenocarcinoma. Cancer Med 6(2):463-470. https://doi.org/10.1002/cam4.993

138. Miyake M, Hori S, Morizawa Y, Tatsumi Y, Nakai Y, Anai S, Torimoto K, Aoki K, Tanaka N, Shimada K, Konishi N, Toritsuka M, Kishimoto T, Rosser CJ, Fujimoto K (2016) CXCL1-mediated interaction of cancer cells with tumor-associated macrophages and cancer-associated fibroblasts promotes tumor progression in human bladder cancer. Neoplasia 18(10):636-646. https://doi.org/ 10.1016/j.neo.2016.08.002

139. Comito G, Giannoni E, Segura CP, Barcellos-de-Souza P, Raspollini MR, Baroni G, Lanciotti M, Serni S, Chiarugi P (2014) Cancer-associated fibroblasts and M2-polarized macrophages synergize during prostate carcinoma progression. Oncogene 33(19):2423-2431. https://doi.org/10.1038/onc.2013. 191

140. Kumar V, Donthireddy L, Marvel D, Condamine T, Wang F, Lavilla-Alonso S, Hashimoto A, Vonteddu P, Behera R, Goins MA, Mulligan C, Nam B, Hockstein N, Denstman F, Shakamuri S, Speicher DW, Weeraratna AT, Chao T, Vonderheide RH, Languino LR, Ordentlich P, Liu Q, Xu X, Lo A, Pure E, Zhang C, Loboda A, Sepulveda MA, Snyder LA, Gabrilovich DI (2017) Cancer-associated fibroblasts neutralize the anti-tumor effect of CSF1 receptor blockade by inducing PMN-MDSC infiltration of tumors. Cancer Cell 32(5):654-668.e655. https://doi.org/10.1016/ j.ccell.2017.10.005

141. Hendry S, Salgado R, Gevaert T, Russell PA, John T, Thapa B, Christie M, van de Vijver K, Estrada MV, Gonzalez-Ericsson PI, 
Sanders M, Solomon B, Solinas C, Van den Eynden G, Allory Y, Preusser M, Hainfellner J, Pruneri G, Vingiani A, Demaria S, Symmans F, Nuciforo P, Comerma L, Thompson EA, Lakhani S, Kim SR, Schnitt S, Colpaert C, Sotiriou C, Scherer SJ, Ignatiadis M, Badve S, Pierce RH, Viale G, Sirtaine N, PenaultLlorca F, Sugie T, Fineberg S, Paik S, Srinivasan A, Richardson A, Wang Y, Chmielik E, Brock J, Johnson DB, Balko J, Wienert S, Bossuyt V, Michiels S, Ternes N, Burchardi N, Luen SJ, Savas P, Klauschen F, Watson PH, Nelson BH, Criscitiello C, O'Toole S, Larsimont D, de Wind R, Curigliano G, Andre F, Lacroix-Triki M, van de Vijver M, Rojo F, Floris G, Bedri S, Sparano J, Rimm D, Nielsen T, Kos Z, Hewitt S, Singh B, Farshid G, Loibl S, Allison KH, Tung N, Adams S, Willard-Gallo K, Horlings HM, Gandhi L, Moreira A, Hirsch F, Dieci MV, Urbanowicz M, Brcic I, Korski K, Gaire F, Koeppen H, Lo A, Giltnane J, Rebelatto MC, Steele KE, Zha J, Emancipator K, Juco JW, Denkert C, Reis-Filho J, Loi S, Fox SB (2017) Assessing tumor-infiltrating lymphocytes in solid tumors: a practical review for pathologists and proposal for a standardized method from the international immunooncology biomarkers working group: part 2: TILs in melanoma, gastrointestinal tract carcinomas, non-small cell lung carcinoma and mesothelioma, endometrial and ovarian carcinomas, squamous cell carcinoma of the head and neck, genitourinary carcinomas, and primary brain tumors. Adv Anat Pathol. https://doi.org/ 10.1097/PAP.0000000000000161

142. Reiser J, Banerjee A (2016) Effector, memory, and dysfunctional CD8(+) T cell fates in the antitumor immune response. J Immunol Res 2016:8941260. https://doi.org/10.1155/2016/8941260

143. Kamphorst JJ, Gottlieb E (2016) Cancer metabolism: friendly neighbours feed tumour cells. Nature 536(7617):401-402. https://doi.org/10.1038/nature19420

144. Abu Aboud O, Habib SL, Trott J, Stewart B, Liang S, Chaudhari AJ, Sutcliffe J, Weiss RH (2017) Glutamine addiction in kidney cancer suppresses oxidative stress and can be exploited for realtime imaging. Cancer Res 77(23):6746-6758. https://doi.org/10. 1158/0008-5472.Can-17-0930

145. Niklison-Chirou MV, Erngren I, Engskog M, Haglof J, Picard D, Remke M, McPolin PHR, Selby M, Williamson D, Clifford SC, Michod D, Hadjiandreou M, Arvidsson T, Pettersson C, Melino G, Marino S (2017) TAp73 is a marker of glutamine addiction in medulloblastoma. Genes Dev 31(17):1738-1753. https://oi.org/ 10.1101/gad.302349.117

146. Finicle BT, Jayashankar V, Edinger AL (2018) Nutrient scavenging in cancer. Nat Rev Cancer 18(10):619-633. https://doi.org/10. 1038/s41568-018-0048-x

147. Fais S, Overholtzer M (2018) Cell-in-cell phenomena in cancer. Nat Rev Cancer 18(12):758-766. https://doi.org/10.1038/s41568018-0073-9

148. Zhang Y, Ertl HC (2016) Starved and asphyxiated: how can CD8(+) T cells within a tumor microenvironment prevent tumor progression. Front Immunol 7:32. https://doi.org/10.3389/fimmu. 2016.00032

149. Patsoukis N, Bardhan K, Chatterjee P, Sari D, Liu B, Bell LN, Karoly ED, Freeman GJ, Petkova V, Seth P, Li L, Boussiotis VA (2015) PD-1 alters T-cell metabolic reprogramming by inhibiting glycolysis and promoting lipolysis and fatty acid oxidation. Nat Commun 6:6692-6692. https://doi.org/10.1038/ncomms7692

150. Saeidi A, Zandi K, Cheok YY, Saeidi H, Wong WF, Lee CYQ, Cheong HC, Yong YK, Larsson M, Shankar EM (2018) T-cell exhaustion in chronic infections: reversing the state of exhaustion and reinvigorating optimal protective immune responses. Front Immunol 9:2569. https://doi.org/10.3389/fimmu.2018.02569

151. Darvin P, Toor SM, Sasidharan Nair V, Elkord E (2018) Immune checkpoint inhibitors: recent progress and potential biomarkers. Exp Mol Med 50(12):165-165. https://doi.org/10.1038/s12276018-0191-1
152. Palmer CS, Hussain T, Duette G, Weller TJ, Ostrowski M, SadaOvalle I, Crowe SM (2016) Regulators of glucose metabolism in CD4(+) and CD8(+) T cells. Int Rev Immunol 35(6):477-488. https://doi.org/10.3109/08830185.2015.1082178

153. Chang CH, Qiu J, O’Sullivan D, Buck MD, Noguchi T, Curtis JD, Chen Q, Gindin M, Gubin MM, van der Windt GJ, Tonc E, Schreiber RD, Pearce EJ, Pearce EL (2015) Metabolic competition in the tumor microenvironment is a driver of cancer progression. Cell 162(6):1229-1241. https://doi.org/10.1016/j.cell.2015. 08.016

154. Cham CM, Driessens G, O'Keefe JP, Gajewski TF (2008) Glucose deprivation inhibits multiple key gene expression events and effector functions in CD8+ T cells. Eur J Immunol 38(9): 2438-2450. https://doi.org/10.1002/eji.200838289

155. Turkcan S, Kiru L, Naczynski DJ, Sasportas LS, Pratx G (2019) Lactic acid accumulation in the tumor microenvironment suppresses (18)F-FDG uptake. Cancer Res 79(2):410-419. https:// doi.org/10.1158/0008-5472.Can-17-0492

156. Kim JW, Tchernyshyov I, Semenza GL, Dang CV (2006) HIF-1mediated expression of pyruvate dehydrogenase kinase: a metabolic switch required for cellular adaptation to hypoxia. Cell Metab 3(3):177-185. https://doi.org/10.1016/j.cmet.2006.02.002

157. Papandreou I, Cairns RA, Fontana L, Lim AL, Denko NC (2006) HIF-1 mediates adaptation to hypoxia by actively downregulating mitochondrial oxygen consumption. Cell Metab 3(3):187-197. https://doi.org/10.1016/j.cmet.2006.01.012

158. Noman MZ, Hasmim M, Messai Y, Terry S, Kieda C, Janji B, Chouaib S (2015) Hypoxia: a key player in antitumor immune response. A review in the theme: cellular responses to hypoxia. Am J Phys Cell Physiol 309(9):C569-C579. https://doi.org/10. 1152/ajpcell.00207.2015

159. Larbi A, Zelba H, Goldeck D, Pawelec G (2010) Induction of HIF1alpha and the glycolytic pathway alters apoptotic and differentiation profiles of activated human T cells. J Leukoc Biol 87(2): 265-273. https://doi.org/10.1189/jlb.0509304

160. Tao JH, Barbi J, Pan F (2015) Hypoxia-inducible factors in T lymphocyte differentiation and function. A review in the theme: cellular responses to hypoxia. Am J Phys Cell Physiol 309(9): C580-C589. https://doi.org/10.1152/ajpcell.00204.2015

161. Takahashi S, Iizumi T, Mashima K, Abe T, Suzuki N (2014) Roles and regulation of ketogenesis in cultured astroglia and neurons under hypoxia and hypoglycemia. ASN Neuro 6(5). https://doi. org/10.1177/1759091414550997

162. Sikalidis AK (2015) Amino acids and immune response: a role for cysteine, glutamine, phenylalanine, tryptophan and arginine in Tcell function and cancer? Pathol Oncol Res 21(1):9-17. https:// doi.org/10.1007/s12253-014-9860-0

163. Sukumar M, Roychoudhuri R, Restifo NP (2015) Nutrient competition: a new axis of tumor immunosuppression. Cell 162(6): 1206-1208. https://doi.org/10.1016/j.cell.2015.08.064

164. Anderson KG, Stromnes IM, Greenberg PD (2017) Obstacles posed by the tumor microenvironment to $\mathrm{T}$ cell activity: a case for synergistic therapies. Cancer Cell 31(3):311-325. https://doi. org/10.1016/j.ccell.2017.02.008

165. Poh AR, Ernst M (2018) Targeting macrophages in cancer: from bench to bedside. Front Oncol 8:49. https://doi.org/10.3389/fonc. 2018.00049

166. Huang SC, Smith AM, Everts B, Colonna M, Pearce EL, Schilling JD, Pearce EJ (2016) Metabolic reprogramming mediated by the mTORC2-IRF4 signaling axis is essential for macrophage alternative activation. Immunity 45(4):817-830. https://doi.org/10. 1016/j.immuni.2016.09.016

167. Liu D, Chang C, Lu N, Wang X, Lu Q, Ren X, Ren P, Zhao D, Wang L, Zhu Y, He F, Tang L (2017) Comprehensive proteomics analysis reveals metabolic reprogramming of tumor-associated macrophages stimulated by the tumor microenvironment. $\mathrm{J}$ 
Proteome Res 16(1):288-297. https://doi.org/10.1021/acs. jproteome.6b00604

168. Netea-Maier RT, Smit JWA, Netea MG (2018) Metabolic changes in tumor cells and tumor-associated macrophages: a mutual relationship. Cancer Lett 413:102-109. https://doi.org/10.1016/j. canlet.2017.10.037

169. Ocana MC, Martinez-Poveda B, Quesada AR, Medina MA (2018) Metabolism within the tumor microenvironment and its implication on cancer progression: an ongoing therapeutic target. Med Res Rev. https://doi.org/10.1002/med.21511

170. Mazzone M, Menga A, Castegna A (2018) Metabolism and TAM functions - it takes two to tango. FEBS J 285(4):700-716. https:// doi.org/10.1111/febs. 14295

171. Yan D, Adeshakin AO, Xu M, Afolabi LO, Zhang G, Chen YH, Wan X (2019) Lipid metabolic pathways confer the immunosuppressive function of myeloid-derived suppressor cells in tumor. Front Immunol 10:1399. https://doi.org/10.3389/fimmu.2019. 01399

172. Eikawa S, Nishida M, Mizukami S, Yamazaki C, Nakayama E, Udono H (2015) Immune-mediated antitumor effect by type 2 diabetes drug, metformin. Proc Natl Acad Sci U S A 112(6): 1809-1814. https://doi.org/10.1073/pnas.1417636112

173. Zarrouk M, Finlay DK, Foretz M, Viollet B, Cantrell DA (2014) Adenosine-mono-phosphate-activated protein kinase-independent effects of metformin in T cells. PLoS One 9(9):e106710. https:// doi.org/10.1371/journal.pone.0106710

174. Rao M, Dodoo E, Zumla A, Maeurer M (2019) Immunometabolism and pulmonary infections: implications for protective immune responses and host-directed therapies. Front Microbiol 10:962. https://doi.org/10.3389/fmicb.2019.00962

175. De Vita MV, Scolfaro C, Santini B, Lezo A, Gobbi F, Buonfrate D, Kimani-Murage EW, Macharia T, Wanjohi M, Rovarini JM, Morino G (2019) Malnutrition, morbidity and infection in the informal settlements of Nairobi, Kenya: an epidemiological study. Ital J Pediatr 45(1):12. https://doi.org/10.1186/s13052-019-06070

176. Ibrahim MK, Zambruni M, Melby CL, Melby PC (2017) Impact of childhood malnutrition on host defense and infection. Clin Microbiol Rev 30(4):919-971. https://doi.org/10.1128/cmr. 00119-16

177. DeBoer MD, Scharf RJ, Leite AM, Ferrer A, Havt A, Pinkerton R, Lima AA, Guerrant RL (2017) Systemic inflammation, growth factors, and linear growth in the setting of infection and malnutrition. Nutrition 33:248-253. https://doi.org/10.1016/j.nut.2016.06. 013

178. Das D, Grais RF, Okiro EA, Stepniewska K, Mansoor R, van der Kam S, Terlouw DJ, Tarning J, Barnes KI, Guerin PJ (2018) Complex interactions between malaria and malnutrition: a systematic literature review. BMC Med 16(1):186. https://doi.org/10. 1186/s12916-018-1177-5

179. Martin SJ, Sabina EP (2019) Malnutrition and associated disorders in tuberculosis and its therapy. J Diet Suppl 16(5):602-610. https://doi.org/10.1080/19390211.2018.1472165

180. Scrimshaw NS, SanGiovanni JP (1997) Synergism of nutrition, infection, and immunity: an overview. Am J Clin Nutr 66(2): 464s-477s. https://doi.org/10.1093/ajcn/66.2.464S

181. Kishton RJ, Sukumar M, Restifo NP (2017) Metabolic regulation of $\mathrm{T}$ cell longevity and function in tumor immunotherapy. Cell Metab 26(1):94-109. https://doi.org/10.1016/j.cmet.2017.06.016

182. Zukiewicz-Sobczak W, Wroblewska P, Zwolinski J, Chmielewska-Badora J, Adamczuk P, Krasowska E, Zagorski J, Oniszczuk A, Piatek J, Silny W (2014) Obesity and poverty paradox in developed countries. Ann Agric Environ Med 21(3): 590-594. https://doi.org/10.5604/12321966.1120608
183. Harrison CA, Taren D (2018) How poverty affects diet to shape the microbiota and chronic disease. Nat Rev Immunol 18(4):279 287. https://doi.org/10.1038/nri.2017.121

184. Kumar H (2019) Immunity and its role in white plague and obesity. Int Rev Immunol 38(4):129-130. https://doi.org/10.1080/ 08830185.2019.1659528

185. Green WD, Beck MA (2017) Obesity impairs the adaptive immune response to influenza virus. Ann Am Thorac Soc 14(Supplement_5):S406-s409. https://doi.org/10.1513/ AnnalsATS.201706-447AW

186. Tagliabue C, Principi N, Giavoli C, Esposito S (2016) Obesity: impact of infections and response to vaccines. Eur J Clin Microbiol Infect Dis 35(3):325-331. https://doi.org/10.1007/ s10096-015-2558-8

187. Beisel WR (1992) History of nutritional immunology: introduction and overview. J Nutr 122(3 Suppl):591-596. https://doi.org/ 10.1093/jn/122.suppl 3.591

188. Scrimshaw NS, Taylor CE, Gordon JE (1959) Interactions of nutrition and infection. Am J Med Sci 237(3):367-403

189. Scrimshaw NS, Taylor CE, Gordon JE (1969) Interactions of nutrition and infection. WHO Chron 23(8):369-374

190. Scrimshaw NS (1966) Synergistic and antagonistic interactions of nutrition and infection. Fed Proc 25(6):1679-1681

191. Scrimshaw NS (2003) Historical concepts of interactions, synergism and antagonism between nutrition and infection. J Nutr 133(1):316s-321s. https://doi.org/10.1093/jn/133.1.316S

192. Scrimshaw NS (2010) INCAP studies of nutrition and infection. Food Nutr Bull 31(1):54-67. https://doi.org/10.1177/ 156482651003100107

193. Ghosh S, Pellett PL, Aw-Hassan A, Mouneime Y, Smriga M, Scrimshaw NS (2008) Impact of lysine-fortified wheat flour on morbidity and immunologic variables among members of rural families in northwest Syria. Food Nutr Bull 29(3):163-171. https://doi.org/10.1177/156482650802900302

194. Ghosh S, Smriga M, Vuvor F, Suri D, Mohammed H, Armah SM, Scrimshaw NS (2010) Effect of lysine supplementation on health and morbidity in subjects belonging to poor peri-urban households in Accra, Ghana. Am J Clin Nutr 92(4):928-939. https://doi.org/ 10.3945/ajen.2009.28834

195. Scrimshaw NS (2010) INCAP studies of endemic goiter and its prevention. Food Nutr Bull 31(1):111-117. https://doi.org/10. $1177 / 156482651003100111$

196. Scrimshaw NS (2010) The origin and development of INCAP. Food Nutr Bull 31(1):4-8. https://doi.org/10.1177/ 156482651003100102

197. Scrimshaw NS (2010) History and early development of INCAP. J Nutr 140(2):394-396. https://doi.org/10.3945/jn.109.114694

198. Scrimshaw NS, Viteri FE (2010) INCAP studies of kwashiorkor and marasmus. Food Nutr Bull 31(1):34-41. https://doi.org/10. $1177 / 156482651003100105$

199. Scrimshaw NS (2007) Prologue: historical introduction. Immunonutrition in health and disease. Br J Nutr 98(Suppl 1): S3-S4. https://doi.org/10.1017/s0007114507833034

200. Grimble RF (2005) Immunonutrition. Curr Opin Gastroenterol 21(2):216-222

201. Cangelosi MJ, Rodday AM, Saunders T, Cohen JT (2014) Evaluation of the economic burden of diseases associated with poor nutrition status. JPEN J Parenter Enteral Nutr 38(2 Suppl): 35s-41s. https://doi.org/10.1177/0148607113514612

202. Krawinkel MB (2012) Interaction of nutrition and infections globally: an overview. Ann Nutr Metab 61(Suppl 1):39-45. https://doi. org/10.1159/000345162

203. Calder PC (2013) Feeding the immune system. Proc Nutr Soc 72(3):299-309. https://doi.org/10.1017/s0029665113001286 
204. Reilly SM, Saltiel AR (2017) Adapting to obesity with adipose tissue inflammation. Nat Rev Endocrinol 13(11):633-643. https:// doi.org/10.1038/nrendo. 2017.90

205. Jun JC, Devera R, Unnikrishnan D, Shin MK, Bevans-Fonti S, Yao Q, Rathore A, Younas H, Halberg N, Scherer PE, Polotsky VY (2017) Adipose HIF-1alpha causes obesity by suppressing brown adipose tissue thermogenesis. J Mol Med 95(3):287-297. https://doi.org/10.1007/s00109-016-1480-6

206. Ryan S (2017) Adipose tissue inflammation by intermittent hypoxia: mechanistic link between obstructive sleep apnoea and metabolic dysfunction. J Physiol 595(8):2423-2430. https://doi.org/ 10.1113/jp273312

207. Takikawa A, Mahmood A, Nawaz A, Kado T, Okabe K, Yamamoto S, Aminuddin A, Senda S, Tsuneyama K, Ikutani M, Watanabe Y, Igarashi Y, Nagai Y, Takatsu K, Koizumi K, Imura J, Goda N, Sasahara M, Matsumoto M, Saeki K, Nakagawa T, Fujisaka S, Usui I, Tobe K (2016) HIF-1alpha in myeloid cells promotes adipose tissue remodeling toward insulin resistance. Diabetes 65(12):3649-3659. https://doi.org/10.2337/db16-0012

208. Karki S, Ngo DTM, Farb MG, Park SY, Saggese SM, Hamburg NM, Carmine B, Hess DT, Walsh K, Gokce N (2017) WNT5A regulates adipose tissue angiogenesis via antiangiogenic VEGFA165b in obese humans. Am J Physiol Heart Circ Physiol 313(1): H200-h206. https://doi.org/10.1152/ajpheart.00776.2016

209. Beigier-Bompadre M, Montagna GN, Kuhl AA, Lozza L, Weiner J 3rd, Kupz A, Vogelzang A, Mollenkopf HJ, Lowe D, Bandermann S, Dorhoi A, Brinkmann V, Matuschewski K, Kaufmann SHE (2017) Mycobacterium tuberculosis infection modulates adipose tissue biology. PLoS Pathog 13(10): e1006676. https://doi.org/10.1371/journal.ppat.1006676

210. Han SJ, Glatman Zaretsky A, Andrade-Oliveira V, Collins N, Dzutsev A, Shaik J, Morais da Fonseca D, Harrison OJ, Tamoutounour S, Byrd AL, Smelkinson M, Bouladoux N, Bliska JB, Brenchley JM, Brodsky IE, Belkaid Y (2017) White adipose tissue is a reservoir for memory $\mathrm{T}$ cells and promotes protective memory responses to infection. Immunity $47(6)$ : 1154-1168.e1156. https://doi.org/10.1016/j.immuni.2017.11.009

211. Hopkins BD, Goncalves MD, Cantley LC (2016) Obesity and Cancer mechanisms: cancer metabolism. J Clin Oncol 34(35): 4277-4283. https://doi.org/10.1200/jco.2016.67.9712

212. Perna S, Peroni G, Faliva MA, Bartolo A, Naso M, Miccono A, Rondanelli M (2017) Sarcopenia and sarcopenic obesity in comparison: prevalence, metabolic profile, and key differences. A cross-sectional study in Italian hospitalized elderly. Aging Clin Exp Res 29(6):1249-1258. https://doi.org/10.1007/s40520-0160701-8

213. Sousa AS, Guerra RS, Fonseca I, Pichel F, Amaral TF (2015) Sarcopenia among hospitalized patients - a cross-sectional study. Clin Nutr 34(6):1239-1244. https://doi.org/10.1016/j.clnu.2014. 12.015

214. Lee DC, Shook RP, Drenowatz C, Blair SN (2016) Physical activity and sarcopenic obesity: definition, assessment, prevalence and mechanism. Future Sci OA 2(3):Fso127. https://doi.org/10. 4155/fsoa-2016-0028

215. Martin L, Birdsell L, Macdonald N, Reiman T, Clandinin MT, McCargar LJ, Murphy R, Ghosh S, Sawyer MB, Baracos VE (2013) Cancer cachexia in the age of obesity: skeletal muscle depletion is a powerful prognostic factor, independent of body mass index. J Clin Oncol 31(12):1539-1547. https://doi.org/10. 1200/jco.2012.45.2722

216. Liu J, Motoyama S, Sato Y, Wakita A, Kawakita Y, Saito H, Minamiya Y (2016) Decreased skeletal muscle mass after neoadjuvant therapy correlates with poor prognosis in patients with esophageal cancer. Anticancer Res 36(12):6677-6685. https:// doi.org/10.21873/anticanres.11278
217. Blauwhoff-Buskermolen S, Versteeg KS, de van der Schueren MA, den Braver NR, Berkhof J, Langius JA, Verheul HM (2016) Loss of muscle mass during chemotherapy is predictive for poor survival of patients with metastatic colorectal cancer. $\mathrm{J}$ Clin Oncol 34(12):1339-1344. https://doi.org/10.1200/jco.2015. 63.6043

218. Cespedes Feliciano EM, Lee VS, Prado CM, Meyerhardt JA, Alexeeff S, Kroenke CH, Xiao J, Castillo AL, Caan BJ (2017) Muscle mass at the time of diagnosis of nonmetastatic colon cancer and early discontinuation of chemotherapy, delays, and dose reductions on adjuvant FOLFOX: the C-SCANS study. Cancer 123(24):4868-4877. https://doi.org/10.1002/cncr.30950

219. Argiles JM (2017) The 2015 ESPEN sir David Cuthbertson lecture: inflammation as the driving force of muscle wasting in cancer. Clin Nutr 36(3):798-803. https://doi.org/10.1016/j.clnu.2016. 05.010

220. VanderVeen BN, Fix DK, Carson JA (2017) Disrupted skeletal muscle mitochondrial dynamics, mitophagy, and biogenesis during cancer cachexia: a role for inflammation. Oxidative Med Cell Longev 2017:3292087. https://doi.org/10.1155/2017/3292087

221. Londhe P, Guttridge DC (2015) Inflammation induced loss of skeletal muscle. Bone 80:131-142. https://doi.org/10.1016/j. bone.2015.03.015

222. Kim J, Lee J (2017) Role of transforming growth factor-beta in muscle damage and regeneration: focused on eccentric muscle contraction. J Exerc Rehabil 13(6):621-626. https://doi.org/10. 12965/jer.1735072.536

223. Flint TR, Fearon DT, Janowitz T (2017) Connecting the metabolic and immune responses to cancer. Trends Mol Med 23(5):451464. https://doi.org/10.1016/j.molmed.2017.03.001

224. Jezek J, Cooper KF, Strich R (2018) Reactive oxygen species and mitochondrial dynamics: the yin and yang of mitochondrial dysfunction and cancer progression. Antioxidants 7(1). https://doi. org/10.3390/antiox7010013

225. Lieffers JR, Bathe OF, Fassbender K, Winget M, Baracos VE (2012) Sarcopenia is associated with postoperative infection and delayed recovery from colorectal cancer resection surgery. Br J Cancer 107(6):931-936. https://doi.org/10.1038/bjc.2012.350

226. Pin F, Couch ME, Bonetto A (2018) Preservation of muscle mass as a strategy to reduce the toxic effects of cancer chemotherapy on body composition. Curr Opin Support Palliat Care 12(4):420-426. https://doi.org/10.1097/spc.0000000000000382

227. Hotamisligil GS (2017) Inflammation, metaflammation and immunometabolic disorders. Nature 542(7640):177-185. https:// doi.org/10.1038/nature21363

228. Walson JL, Berkley JA (2018) The impact of malnutrition on childhood infections. Curr Opin Infect Dis 31(3):231-236. https://doi.org/10.1097/qco.0000000000000448

229. Cunningham-Rundles S, Lin H, Ho-Lin D, Dnistrian A, Cassileth BR, Perlman JM (2009) Role of nutrients in the development of neonatal immune response. Nutr Rev 67(Suppl 2):S152-S163. https://doi.org/10.1111/j.1753-4887.2009.00236.x

230. Victora CG, Bahl R, Barros AJD, França GVA, Horton S, Krasevec J, Murch S, Sankar MJ, Walker N, Rollins NC (2016) Breastfeeding in the 21st century: epidemiology, mechanisms, and lifelong effect. Lancet 387(10017):475-490. https://doi.org/ 10.1016/S0140-6736(15)01024-7

231. Stechmiller JK (2010) Understanding the role of nutrition and wound healing. Nutr Clin Pract 25(1):61-68. https://doi.org/10. $1177 / 0884533609358997$

232. Keller HH, Vesnaver E, Davidson B, Allard J, Laporte M, Bernier P, Payette H, Jeejeebhoy K, Duerksen D, Gramlich L (2014) Providing quality nutrition care in acute care hospitals: perspectives of nutrition care personnel. J Hum Nutr Diet 27(2):192-202. https://doi.org/10.1111/jhn. 12170 
233. Rosen BS, Maddox PJ, Ray N (2013) A position paper on how cost and quality reforms are changing healthcare in America: focus on nutrition. JPEN J Parenter Enteral Nutr 37(6):796-801. https:// doi.org/10.1177/0148607113492337

234. Tappenden KA, Quatrara B, Parkhurst ML, Malone AM, Fanjiang G, Ziegler TR (2013) Critical role of nutrition in improving quality of care: an interdisciplinary call to action to address adult hospital malnutrition. Medsurg Nurs 22(3):147-165

235. Arends J, Baracos V, Bertz H, Bozzetti F, Calder PC, Deutz NEP, Erickson N, Laviano A, Lisanti MP, Lobo DN, McMillan DC, Muscaritoli M, Ockenga J, Pirlich M, Strasser F, de van der Schueren M, Van Gossum A, Vaupel P, Weimann A (2017) ESPEN expert group recommendations for action against cancer-related malnutrition. Clin Nutr 36(5):1187-1196. https:// doi.org/10.1016/j.clnu.2017.06.017

236. Caillet P, Liuu E, Raynaud Simon A, Bonnefoy M, Guerin O, Berrut G, Lesourd B, Jeandel C, Ferry M, Rolland Y, Paillaud E (2017) Association between cachexia, chemotherapy and outcomes in older cancer patients: a systematic review. Clin Nutr 36(6):1473-1482. https://doi.org/10.1016/j.clnu.2016.12.003

237. Fukuda Y, Yamamoto K, Hirao M, Nishikawa K, Maeda S, Haraguchi N, Miyake M, Hama N, Miyamoto A, Ikeda M, Nakamori S, Sekimoto M, Fujitani K, Tsujinaka T (2015) Prevalence of malnutrition among gastric cancer patients undergoing gastrectomy and optimal preoperative nutritional support for preventing surgical site infections. Ann Surg Oncol 22(Suppl 3):S778-S785. https://doi.org/10.1245/s10434-015-4820-9

238. Kang MC, Kim JH, Ryu SW, Moon JY, Park JH, Park JK, Park JH, Baik HW, Seo JM, Son MW, Song GA, Shin DW, Shin YM, Ahn HY, Yang HK, Yu HC, Yun IJ, Lee JG, Lee JM, Lee JH, Lee TH, Yim H, Jeon HJ, Jung K, Jung MR, Jeong CY, Lim HS, Hong SK (2018) Prevalence of malnutrition in hospitalized patients: a multicenter cross-sectional study. J Korean Med Sci 33(2):e10. https://doi.org/10.3346/jkms.2018.33.e10

239. Planas M, Alvarez-Hernandez J, Leon-Sanz M, Celaya-Perez S, Araujo K, Garcia de Lorenzo A (2016) Prevalence of hospital malnutrition in cancer patients: a sub-analysis of the PREDyCES(R) study. Support Care Cancer 24(1):429-435. https://doi.org/10.1007/s00520-015-2813-7

240. Na BG, Han SS, Cho YA, Wie GA, Kim JY, Lee JM, Lee SD, Kim SH, Park SJ (2018) Nutritional status of patients with cancer: a prospective cohort study of 1,588 hospitalized patients. Nutr Cancer 70(8):1228-1236. https://doi.org/10.1080/01635581. 2019.1578392

241. Matson V, Fessler J, Bao R, Chongsuwat T, Zha Y, Alegre ML, Luke JJ, Gajewski TF (2018) The commensal microbiome is associated with anti-PD-1 efficacy in metastatic melanoma patients. Science 359(6371):104-108. https://doi.org/10.1126/science. aao3290

242. Routy B, Le Chatelier E, Derosa L, Duong CPM, Alou MT, Daillere R, Fluckiger A, Messaoudene M, Rauber C, Roberti MP, Fidelle M, Flament C, Poirier-Colame V, Opolon P, Klein C, Iribarren K, Mondragon L, Jacquelot N, Qu B, Ferrere G, Clemenson C, Mezquita L, Masip JR, Naltet C, Brosseau S, Kaderbhai C, Richard C, Rizvi H, Levenez F, Galleron N, Quinquis B, Pons N, Ryffel B, Minard-Colin V, Gonin P, Soria JC, Deutsch E, Loriot Y, Ghiringhelli F, Zalcman G, Goldwasser F, Escudier B, Hellmann MD, Eggermont A, Raoult D, Albiges L, Kroemer G, Zitvogel L (2018) Gut microbiome influences efficacy of PD-1-based immunotherapy against epithelial tumors. Science 359(6371):91-97. https://doi.org/10.1126/science. aan 3706

243. Wirbel J, Pyl PT, Kartal E, Zych K, Kashani A, Milanese A, Fleck JS, Voigt AY, Palleja A, Ponnudurai R, Sunagawa S, Coelho LP, Schrotz-King P, Vogtmann E, Habermann N, Nimeus E, Thomas AM, Manghi P, Gandini S, Serrano D, Mizutani S, Shiroma H,
Shiba S, Shibata T, Yachida S, Yamada T, Waldron L, Naccarati A, Segata N, Sinha R, Ulrich CM, Brenner H, Arumugam M, Bork P, Zeller G (2019) Meta-analysis of fecal metagenomes reveals global microbial signatures that are specific for colorectal cancer. Nat Med 25(4):679-689. https://doi.org/10.1038/s41591019-0406-6

244. Cheung SG, Goldenthal AR, Uhlemann AC, Mann JJ, Miller JM, Sublette ME (2019) Systematic review of gut microbiota and major depression. Front Psychiatry 10:34. https://doi.org/10.3389/ fpsyt.2019.00034

245. Lazar V, Ditu LM, Pircalabioru GG, Picu A, Petcu L, Cucu N, Chifiriuc MC (2019) Gut microbiota, host organism, and diet trialogue in diabetes and obesity. Front Nutr 6:21. https://doi.org/10. 3389/fnut.2019.00021

246. Lee KH, Gordon A, Shedden K, Kuan G, Ng S, Balmaseda A, Foxman B (2019) The respiratory microbiome and susceptibility to influenza virus infection. PLoS One 14(1):e0207898. https:// doi.org/10.1371/journal.pone.0207898

247. Namasivayam S, Sher A, Glickman MS, Wipperman MF (2018) The microbiome and tuberculosis: early evidence for cross talk. MBio 9(5). https://doi.org/10.1128/mBio.01420-18

248. Zimmermann M, Zimmermann-Kogadeeva M, Wegmann R, Goodman AL (2019) Separating host and microbiome contributions to drug pharmacokinetics and toxicity. Science 363(6427). https://doi.org/10.1126/science.aat9931

249. Thomas S, Izard J, Walsh E, Batich K, Chongsathidkiet P, Clarke G, Sela DA, Muller AJ, Mullin JM, Albert K, Gilligan JP, DiGuilio K, Dilbarova R, Alexander W, Prendergast GC (2017) The host microbiome regulates and maintains human health: a primer and perspective for non-microbiologists. Cancer Res 77(8):1783-1812. https://doi.org/10.1158/0008-5472.Can-162929

250. Karl JP, Hatch AM, Arcidiacono SM, Pearce SC, PantojaFeliciano IG, Doherty LA, Soares JW (2018) Effects of psychological, environmental and physical stressors on the gut microbiota. Front Microbiol 9:2013. https://doi.org/10.3389/fmicb.2018. 02013

251. Picca A, Fanelli F, Calvani R, Mule G, Pesce V, Sisto A, Pantanelli C, Bernabei R, Landi F, Marzetti E (2018) Gut dysbiosis and muscle aging: searching for novel targets against sarcopenia. Mediat Inflamm 2018:7026198. https://doi.org/10. 1155/2018/7026198

252. LeBlanc JG, Milani C, de Giori GS, Sesma F, van Sinderen D, Ventura M (2013) Bacteria as vitamin suppliers to their host: a gut microbiota perspective. Curr Opin Biotechnol 24(2):160-168. https://doi.org/10.1016/j.copbio.2012.08.005

253. Mills S, Stanton C, Lane JA, Smith GJ, Ross RP (2019) Precision nutrition and the microbiome, part I: current state of the science. Nutrients 11(4). https://doi.org/10.3390/nu11040923

254. Claesson MJ, Cusack S, O’Sullivan O, Greene-Diniz R, de Weerd H, Flannery E, Marchesi JR, Falush D, Dinan T, Fitzgerald G, Stanton C, van Sinderen D, O'Connor M, Harnedy N, O'Connor K, Henry C, O'Mahony D, Fitzgerald AP, Shanahan F, Twomey C, Hill C, Ross RP, O’Toole PW (2011) Composition, variability, and temporal stability of the intestinal microbiota of the elderly. Proc Natl Acad Sci U S A 108(Suppl 1):4586-4591. https://doi. org/10.1073/pnas. 1000097107

255. Claesson MJ, Jeffery IB, Conde S, Power SE, O'Connor EM, Cusack S, Harris HM, Coakley M, Lakshminarayanan B, O'Sullivan O, Fitzgerald GF, Deane J, O'Connor M, Harnedy N, O'Connor K, O'Mahony D, van Sinderen D, Wallace M, Brennan L, Stanton C, Marchesi JR, Fitzgerald AP, Shanahan F, Hill C, Ross RP, O'Toole PW (2012) Gut microbiota composition correlates with diet and health in the elderly. Nature 488(7410): 178-184. https://doi.org/10.1038/nature11319 
256. Grosicki GJ, Fielding RA, Lustgarten MS (2018) Gut microbiota contribute to age-related changes in skeletal muscle size, composition, and function: biological basis for a gut-muscle axis. Calcif Tissue Int 102(4):433-442. https://doi.org/10.1007/s00223-0170345-5

257. Singh RK, Chang HW, Yan D, Lee KM, Ucmak D, Wong K, Abrouk M, Farahnik B, Nakamura M, Zhu TH, Bhutani T, Liao W (2017) Influence of diet on the gut microbiome and implications for human health. J Transl Med 15(1):73. https://doi.org/10. 1186/s12967-017-1175-y

258. Romano KA, Vivas EI, Amador-Noguez D, Rey FE (2015) Intestinal microbiota composition modulates choline bioavailability from diet and accumulation of the proatherogenic metabolite trimethylamine-N-oxide. MBio 6(2):e02481. https://doi.org/10. 1128/mBio.02481-14

259. Bibbo S, Ianiro G, Giorgio V, Scaldaferri F, Masucci L, Gasbarrini A, Cammarota G (2016) The role of diet on gut microbiota composition. Eur Rev Med Pharmacol Sci 20(22):4742-4749

260. Coelho OGL, Candido FG, Alfenas RCG (2018) Dietary fat and gut microbiota: mechanisms involved in obesity control. Crit Rev Food Sci Nutr:1-9. https://doi.org/10.1080/10408398.2018. 1481821

261. Wu GD, Chen J, Hoffmann C, Bittinger K, Chen YY, Keilbaugh SA, Bewtra M, Knights D, Walters WA, Knight R, Sinha R, Gilroy E, Gupta K, Baldassano R, Nessel L, Li H, Bushman FD, Lewis JD (2011) Linking long-term dietary patterns with gut microbial enterotypes. Science 334(6052):105-108. https://doi.org/ 10.1126/science. 1208344

262. Lopez-Legarrea P, Fuller NR, Zulet MA, Martinez JA, Caterson ID (2014) The influence of Mediterranean, carbohydrate and high protein diets on gut microbiota composition in the treatment of obesity and associated inflammatory state. Asia Pac J Clin Nutr 23(3):360-368. https://doi.org/10.6133/apjen.2014.23.3.16

263. Biesalski HK (2016) Nutrition meets the microbiome: micronutrients and the microbiota. Ann N Y Acad Sci 1372(1): 53-64. https://doi.org/10.1111/nyas.13145

264. Subramanian S, Huq S, Yatsunenko T, Haque R, Mahfuz M, Alam MA, Benezra A, DeStefano J, Meier MF, Muegge BD, Barratt MJ, VanArendonk LG, Zhang Q, Province MA, Petri WA Jr, Ahmed T, Gordon JI (2014) Persistent gut microbiota immaturity in malnourished Bangladeshi children. Nature 510(7505):417-421. https://doi.org/10.1038/nature13421

265. Clooney AG, Sutton TDS, Shkoporov AN, Holohan RK, Daly KM, O'Regan O, Ryan FJ, Draper LA, Plevy SE, Ross RP, Hill C (2019) Whole-virome analysis sheds light on viral dark matter in inflammatory bowel disease. Cell Host Microbe 26(6):764-778 e765. https://doi.org/10.1016/j.chom.2019.10.009

266. Shkoporov AN, Clooney AG, Sutton TDS, Ryan FJ, Daly KM, Nolan JA, McDonnell SA, Khokhlova EV, Draper LA, Forde A, Guerin E, Velayudhan V, Ross RP, Hill C (2019) The human gut virome is highly diverse, stable, and individual specific. Cell Host Microbe 26(4):527-541 e525. https://doi.org/10.1016/j.chom. 2019.09.009

267. Tabatabaeizadeh SA, Tafazoli N, Ferns GA, Avan A, GhayourMobarhan M (2018) Vitamin D, the gut microbiome and inflammatory bowel disease. J Res Med Sci 23:75. https://doi.org/10. 4103/jrms.JRMS_606_17

268. Montoya D, Inkeles MS, Liu PT, Realegeno S, Teles RM, Vaidya P, Munoz MA, Schenk M, Swindell WR, Chun R, Zavala K, Hewison M, Adams JS, Horvath S, Pellegrini M, Bloom BR, Modlin RL (2014) IL-32 is a molecular marker of a host defense network in human tuberculosis. Sci Transl Med 6(250):250ra114. https://doi.org/10.1126/scitranslmed.3009546

269. Kuroda K, Okumura K, Isogai H, Isogai E (2015) The human cathelicidin antimicrobial peptide LL-37 and mimics are potential anticancer drugs. Front Oncol 5:144. https://doi.org/10.3389/fonc. 2015.00144

270. Cuperus T, Kraaij MD, Zomer AL, van Dijk A, Haagsman HP (2018) Immunomodulation and effects on microbiota after in ovo administration of chicken cathelicidin-2. PLoS One 13(6): e0198188. https://doi.org/10.1371/journal.pone.0198188

271. Yoshimura T, McLean MH, Dzutsev AK, Yao X, Chen K, Huang J, Gong W, Zhou J, Xiang Y, J HB, O'Huigin C, Thovarai V, Tessarollo L, Durum SK, Trinchieri G, Bian XW, Wang JM (2018) The antimicrobial peptide CRAMP is essential for colon homeostasis by maintaining microbiota balance. J Immunol 200(6):2174-2185. https://doi.org/10.4049/jimmunol.1602073

272. Dang AT, Marsland BJ (2019) Microbes, metabolites, and the gutlung axis. Mucosal Immunol 12(4):843-850. https://doi.org/10. 1038/s41385-019-0160-6

273. Bacher P, Hohnstein T, Beerbaum E, Rocker M, Blango MG, Kaufmann S, Rohmel J, Eschenhagen P, Grehn C, Seidel K, Rickerts V, Lozza L, Stervbo U, Nienen M, Babel N, Milleck J, Assenmacher M, Cornely OA, Ziegler M, Wisplinghoff $\mathrm{H}$, Heine G, Worm M, Siegmund B, Maul J, Creutz P, Tabeling C, RuwweGlosenkamp C, Sander LE, Knosalla C, Brunke S, Hube B, Kniemeyer O, Brakhage AA, Schwarz C, Scheffold A (2019) Human anti-fungal Th17 immunity and pathology rely on crossreactivity against Candida albicans. Cell 176(6):13401355.e1315. https://doi.org/10.1016/j.cell.2019.01.041

274. Mjosberg J, Rao A (2018) Lung inflammation originating in the gut. Science 359(6371):36-37. https://doi.org/10.1126/science. aar4301

275. Baktash A, Terveer EM, Zwittink RD, Hornung BVH, Corver J, Kuijper EJ, Smits WK (2018) Mechanistic insights in the success of fecal microbiota transplants for the treatment of Clostridium difficile infections. Front Microbiol 9:1242. https://doi.org/10. 3389/fmicb.2018.01242

276. Hudson LE, Anderson SE, Corbett AH, Lamb TJ (2017) Gleaning insights from fecal microbiota transplantation and probiotic studies for the rational design of combination microbial therapies. Clin Microbiol Rev 30(1):191-231. https://doi.org/10.1128/cmr. 00049-16

277. Hughes RL, Marco ML, Hughes JP, Keim NL, Kable ME (2019) The role of the gut microbiome in predicting response to diet and the development of precision nutrition models-part I: overview of current methods. Adv Nutr. https://doi.org/10.1093/advances/ nmz022

278. Aversa Z, Costelli P, Muscaritoli M (2017) Cancer-induced muscle wasting: latest findings in prevention and treatment. Ther Adv Med Oncol 9(5):369-382. https://doi.org/10.1177/ 1758834017698643

279. Fukawa T, Yan-Jiang BC, Min-Wen JC, Jun-Hao ET, Huang D, Qian CN, Ong P, Li Z, Chen S, Mak SY, Lim WJ, Kanayama HO, Mohan RE, Wang RR, Lai JH, Chua C, Ong HS, Tan KK, Ho YS, Tan IB, Teh BT, Shyh-Chang N (2016) Excessive fatty acid oxidation induces muscle atrophy in cancer cachexia. Nat Med 22(6): 666-671. https://doi.org/10.1038/nm.4093

280. Sturgeon KM, Mathis KM, Rogers CJ, Schmitz KH, Waning DL (2019) Cancer- and chemotherapy-induced musculoskeletal degradation. JBMR Plus 3(3):e10187. https://doi.org/10.1002/jbm4. 10187

281. Ikemoto S, Sugimura K, Yoshida N, Wada S, Yamamoto K, Kishimoto T (2000) TNF alpha, IL-1 beta and IL-6 production by peripheral blood monocytes in patients with renal cell carcinoma. Anticancer Res 20(1a):317-321

282. Matthys P, Billiau A (1997) Cytokines and cachexia. Nutrition 13(9):763-770

283. Patel HJ, Patel BM (2017) TNF-alpha and cancer cachexia: molecular insights and clinical implications. Life Sci 170:56-63. https://doi.org/10.1016/j.lfs.2016.11.033 
284. Shyh-Chang N (2017) Metabolic changes during cancer cachexia pathogenesis. Adv Exp Med Biol 1026:233-249. https://doi.org/ 10.1007/978-981-10-6020-5 11

285. Fearon KC, Glass DJ, Guttridge DC (2012) Cancer cachexia: mediators, signaling, and metabolic pathways. Cell Metab 16(2): 153-166. https://doi.org/10.1016/j.cmet.2012.06.011

286. Daas SI, Rizeq BR, Nasrallah GK (2018) Adipose tissue dysfunction in cancer cachexia. J Cell Physiol 234(1):13-22. https://doi. org/10.1002/jcp.26811

287. Dalal S (2019) Lipid metabolism in cancer cachexia. Ann Palliat Med 8(1):13-23. https://doi.org/10.21037/apm.2018.10.01

288. Sakuma K, Aoi W, Yamaguchi A (2017) Molecular mechanism of sarcopenia and cachexia: recent research advances. Pflugers Arch 469(5-6):573-591. https://doi.org/10.1007/s00424-016-1933-3

289. Sandri M (2016) Protein breakdown in cancer cachexia. Semin Cell Dev Biol 54:11-19. https://doi.org/10.1016/j.semcdb.2015. 11.002

290. Liu Z, Sin KWT, Ding H, Doan HA, Gao S, Miao H, Wei Y, Wang Y, Zhang G, Li YP (2018) p38beta MAPK mediates ULK1-dependent induction of autophagy in skeletal muscle of tumor-bearing mice. Cell Stress 2(11):311-324. https://doi.org/ 10.15698/cst2018.11.163

291. Marzetti E, Lorenzi M, Landi F, Picca A, Rosa F, Tanganelli F, Galli M, Doglietto GB, Pacelli F, Cesari M, Bernabei R, Calvani R, Bossola M (2017) Altered mitochondrial quality control signaling in muscle of old gastric cancer patients with cachexia. Exp Gerontol 87(Pt A):92-99. https://doi.org/10.1016/j.exger.2016. 10.003

292. Pin F, Barreto R, Couch ME, Bonetto A, O'Connell TM (2019) Cachexia induced by cancer and chemotherapy yield distinct perturbations to energy metabolism. J Cachexia Sarcopenia Muscle 10(1):140-154. https://doi.org/10.1002/jcsm. 12360

293. Belloum Y, Rannou-Bekono F, Favier FB (2017) Cancer-induced cardiac cachexia: pathogenesis and impact of physical activity (review). Oncol Rep 37(5):2543-2552. https://doi.org/10.3892/ or.2017.5542

294. Coletti D (2018) Chemotherapy-induced muscle wasting: an update. Eur J Transl Myol 28(2):7587. https://doi.org/10.4081/ejtm. 2018.7587

295. Moreira-Pais A, Ferreira R, Gil da Costa R (2018) Platinuminduced muscle wasting in cancer chemotherapy: mechanisms and potential targets for therapeutic intervention. Life Sci 208:19. https://doi.org/10.1016/j.lfs.2018.07.010

296. Akyol M, Demir L, Alacacioglu A, Ellidokuz H, Kucukzeybek Y, Yildiz Y, Gumus Z, Bayoglu V, Yildiz I, Salman T, Varol U, Kucukzeybek B, Demir L, Dirican A, Sutcu R, Tarhan MO (2016) The effects of adjuvant endocrine treatment on serum leptin, serum adiponectin and body composition in patients with breast cancer: the Izmir Oncology Group (IZOG) Study. Chemotherapy 61(2):57-64. https://doi.org/10.1159/000440944

297. Capozzi LC, McNeely ML, Lau HY, Reimer RA, Giese-Davis J, Fung TS, Culos-Reed SN (2016) Patient-reported outcomes, body composition, and nutrition status in patients with head and neck cancer: results from an exploratory randomized controlled exercise trial. Cancer 122(8):1185-1200. https://doi.org/10.1002/cncr. 29863

298. Pedersen B, Delmar C, Bendtsen MD, Bosaeus I, Carus A, Falkmer U, Groenkjaer M (2017) Changes in weight and body composition among women with breast cancer during and after adjuvant treatment: a prospective follow-up study. Cancer Nurs 40(5):369-376. https://doi.org/10.1097/ncc.0000000000000426

299. Rier HN, Jager A, Sleijfer S, van Rosmalen J, Kock M, Levin MD (2018) Changes in body composition and muscle attenuation during taxane-based chemotherapy in patients with metastatic breast cancer. Breast Cancer Res Treat 168(1):95-105. https://doi.org/ 10.1007/s10549-017-4574-0
300. Blackburn GL (1992) Nutrition and inflammatory events: highly unsaturated fatty acids (omega-3 vs omega-6) in surgical injury. Proc Soc Exp Biol Med 200(2):183-188. https://doi.org/10.3181/ 00379727-200-43414

301. Grimble RF (1992) Dietary manipulation of the inflammatory response. Proc Nutr Soc 51(2):285-294

302. Lefkowith JB, Morrison A, Lee V, Rogers M (1990) Manipulation of the acute inflammatory response by dietary polyunsaturated fatty acid modulation. J Immunol 145(5):1523-1529

303. Wan JM, Haw MP, Blackburn GL (1989) Nutrition, immune function, and inflammation: an overview. Proc Nutr Soc 48(3): 315-335

304. Grimble RF (2001) Nutritional modulation of immune function. Proc Nutr Soc 60(3):389-397

305. Grimble RF (1994) Nutritional antioxidants and the modulation of inflammation: theory and practice. New Horiz 2(2):175-185

306. Gostner JM, Becker K, Ueberall F, Fuchs D (2015) The good and bad of antioxidant foods: an immunological perspective. Food Chem Toxicol 80:72-79. https://doi.org/10.1016/j.fct.2015.02. 012

307. Arends J, Bachmann P, Baracos V, Barthelemy N, Bertz H, Bozzetti F, Fearon K, Hutterer E, Isenring E, Kaasa S, Krznaric Z, Laird B, Larsson M, Laviano A, Muhlebach S, Muscaritoli M, Oldervoll L, Ravasco P, Solheim T, Strasser F, de van der Schueren M, Preiser JC (2017) ESPEN guidelines on nutrition in cancer patients. Clin Nutr 36(1):11-48. https://doi.org/10. 1016/j.clnu.2016.07.015

308. Çehrelli R (2018) Molecular nutritional immunology and cancer. J Oncol Sci 4:40-46

309. Grimble G (1994) Possible role of short-term parenteral nutrition with fat emulsions for development of haemophagocytosis with multiple organ failure in a patient with traumatic brain injury Roth B, Grande PO, Nillson-Ehle P and Eliasson I. Intensive Care Med 1993; 19: 111-114. Clin Nutr 13 (2):127

310. Grimble G (1994) Can daily dietary arginine supplement affect the function and subpopulation of lymphocytes in patients with advanced gastric cancer? Wu C-W, Chi C-W, Chiu C-C, Liu W-Y, P'eng F-K and Wang S-R. Digestion 1993; 54: 118-124. Clin Nutr 13 (2): $127-128$

311. Ramalho R, Ramalho P, Couto N, Pereira P (2017) Omega-3 therapeutic supplementation in a patient with metastatic adenocarcinoma of the pancreas with muscle mass depletion. Eur J Clin Nutr 71(6):795-797. https://doi.org/10.1038/ejen.2017.47

312. Burns CP, Halabi S, Clamon G, Kaplan E, Hohl RJ, Atkins JN, Schwartz MA, Wagner BA, Paskett E (2004) Phase II study of high-dose fish oil capsules for patients with cancer-related cachexia. Cancer 101(2):370-378. https://doi.org/10.1002/cncr.20362

313. Rosenthal MD, Carrott PW, Patel J, Kiraly L, Martindale RG (2016) Parenteral or enteral arginine supplementation safety and efficacy. J Nutr 146(12):2594s-2600s. https://doi.org/10.3945/jn. 115.228544

314. Mariette C (2015) Immunonutrition. J Visc Surg 152(Suppl 1): S14-S17. https://doi.org/10.1016/s1878-7886(15)30005-9

315. Martin RC 2nd, Agle S, Schlegel M, Hayat T, Scoggins CR, McMasters KM, Philips P (2017) Efficacy of preoperative immunonutrition in locally advanced pancreatic cancer undergoing irreversible electroporation (IRE). Eur J Surg Oncol 43(4): 772-779. https://doi.org/10.1016/j.ejso.2017.01.002

316. Peker KD, Ozkanli SS, Akyuz C, Uzun O, Yasar NF, Duman M, Yol S (2017) Preoperative immunonutrition regulates tumor infiltrative lymphocytes and increases tumor angiogenesis in gastric cancer patients. Arch Med Sci 13(6):1365-1372. https://doi.org/ 10.5114/aoms.2016.60054

317. Thornblade LW, Varghese TK Jr, Shi X, Johnson EK, Bastawrous A, Billingham RP, Thirlby R, Fichera A, Flum DR (2017) Preoperative immunonutrition and elective colorectal resection 
outcomes. Dis Colon Rectum 60(1):68-75. https://doi.org/10. 1097/dcr.0000000000000740

318. Howes N, Atkinson C, Thomas S, Lewis SJ (2018) Immunonutrition for patients undergoing surgery for head and neck cancer. Cochrane Database Syst Rev 8:Cd010954. https:// doi.org/10.1002/14651858.CD010954.pub2

319. Mueller SA, Mayer C, Bojaxhiu B, Aeberhard C, Schuetz P, Stanga Z, Giger R (2019) Effect of preoperative immunonutrition on complications after salvage surgery in head and neck cancer. $\mathrm{J}$ Otolaryngol Head Neck Surg 48(1):25. https://doi.org/10.1186/ s40463-019-0345-8

320. Song GM, Tian X, Liang H, Yi LJ, Zhou JG, Zeng Z, Shuai T, Ou YX, Zhang L, Wang Y (2015) Role of enteral immunonutrition in patients undergoing surgery for gastric cancer: a systematic review and meta-analysis of randomized controlled trials. Medicine (Baltimore) 94(31):e1311. https://doi.org/10.1097/md. 0000000000001311

321. Alito MA, de Aguilar-Nascimento JE (2016) Multimodal perioperative care plus immunonutrition versus traditional care in total hip arthroplasty: a randomized pilot study. Nutr J 15:34. https:// doi.org/10.1186/s12937-016-0153-1

322. Kamocki Z, Matowicka-Karna J, Gryko M, Zareba K, Kedra B, Kemona $H$ (2013) The effect of perioperative immunonutrition on the phagocytic activity of blood platelets in advanced gastric cancer patients. Clin Dev Immunol 2013:435672. https://doi.org/10. $1155 / 2013 / 435672$

323. Plank LD, Mathur S, Gane EJ, Peng SL, Gillanders LK, McIlroy K, Chavez CP, Calder PC, McCall JL (2015) Perioperative immunonutrition in patients undergoing liver transplantation: a randomized double-blind trial. Hepatology 61(2):639-647. https://doi.org/10.1002/hep.27433

324. Camp KM, Trujillo E (2014) Position of the academy of nutrition and dietetics: nutritional genomics. J Acad Nutr Diet 114(2):299312. https://doi.org/10.1016/j.jand.2013.12.001

325. Cui J, Zhou B, Ross SA, Zempleni J (2017) Nutrition, microRNAs, and human health. Adv Nutr 8(1):105-112. https:// doi.org/10.3945/an.116.013839

326. Fenech MF (2014) Nutriomes and personalised nutrition for DNA damage prevention, telomere integrity maintenance and cancer growth control. Cancer Treat Res 159:427-441. https://doi.org/ 10.1007/978-3-642-38007-5 24

327. Bordoni A, Capozzi F (2014) Foodomics for healthy nutrition. Curr Opin Clin Nutr Metab Care 17(5):418-424. https://doi.org/ 10.1097/mco.0000000000000089

328. Ramos-Lopez O, Milagro FI, Allayee H, Chmurzynska A, Choi MS, Curi R, De Caterina R, Ferguson LR, Goni L, Kang JX, Kohlmeier M, Marti A, Moreno LA, Perusse L, Prasad C, Qi L, Reifen R, Riezu-Boj JI, San-Cristobal R, Santos JL, Martinez JA (2017) Guide for current nutrigenetic, nutrigenomic, and nutriepigenetic approaches for precision nutrition involving the prevention and management of chronic diseases associated with obesity. J Nutrigenet Nutrigenomics 10(1-2):43-62. https://doi. org/10.1159/000477729

329. Remely M, Stefanska B, Lovrecic L, Magnet U, Haslberger AG (2015) Nutriepigenomics: the role of nutrition in epigenetic control of human diseases. Curr Opin Clin Nutr Metab Care 18(4): 328-333. https://doi.org/10.1097/mco.0000000000000180

330. Minihane AM, Khan S, Leigh-Firbank EC, Talmud P, Wright JW, Murphy MC, Griffin BA, Williams CM (2000) ApoE polymorphism and fish oil supplementation in subjects with an atherogenic lipoprotein phenotype. Arterioscler Thromb Vasc Biol 20(8): 1990-1997

331. Grimble RF, Howell WM, O’Reilly G, Turner SJ, Markovic O, Hirrell S, East JM, Calder PC (2002) The ability of fish oil to suppress tumor necrosis factor alpha production by peripheral blood mononuclear cells in healthy men is associated with polymorphisms in genes that influence tumor necrosis factor alpha production. Am J Clin Nutr 76(2):454-459. https://doi.org/10. 1093/ajen/76.2.454

332. Paoloni-Giacobino A, Grimble R, Pichard C (2003) Genomic interactions with disease and nutrition. Clin Nutr 22(6):507-514

333. Costa MD, Vieira de Melo CY, Amorim AC, Cipriano Torres Dde O, Dos Santos AC (2016) Association between nutritional status, inflammatory condition, and prognostic indexes with postoperative complications and clinical outcome of patients with gastrointestinal neoplasia. Nutr Cancer 68(7):1108-1114. https://doi.org/ 10.1080/01635581.2016.1206578

334. Perez-Cruz E, Camacho-Limas CP (2017) Association of nutritional status and functional capacity in gastrointestinal cancer patients. Gac Med Mex 153(5):575-580. https://doi.org/10.24875/ gmm. 17002776

335. Wang Y, Zheng J, Gao Z, Han X, Qiu F (2018) Investigation on nutritional risk assessment and nutritional support status of surgical patients with colorectal cancer. J buon 23(1):62-67

336. Zhang L, Lu Y, Fang Y (2014) Nutritional status and related factors of patients with advanced gastrointestinal cancer. Br J Nutr 111(7):1239-1244. https://doi.org/10.1017/ s000711451300367x

337. Guertin MH, Robitaille K, Pelletier JF, Duchesne T, Julien P, Savard J, Bairati I, Fradet V (2018) Effects of concentrated longchain omega-3 polyunsaturated fatty acid supplementation before radical prostatectomy on prostate cancer proliferation, inflammation, and quality of life: study protocol for a phase IIb, randomized, double-blind, placebo-controlled trial. BMC Cancer 18(1): 64. https://doi.org/10.1186/s12885-017-3979-9

338. Kopeina GS, Senichkin VV, Zhivotovsky B (2017) Caloric restriction - a promising anti-cancer approach: from molecular mechanisms to clinical trials. Biochim Biophys Acta Rev Cancer 1867(1):29-41. https://doi.org/10.1016/j.bbcan.2016.11. 002

339. Lien EC, Lau AN, Vander Heiden MG (2019) Putting the $\mathrm{K}(+)$ in $\mathrm{K}(+)$ aloric restriction. Immunity 50(5):1129-1131. https://doi. org/10.1016/j.immuni.2019.04.016

340. Vodnala SK, Eil R, Kishton RJ, Sukumar M, Yamamoto TN, Ha NH, Lee PH, Shin M, Patel SJ, Yu Z, Palmer DC, Kruhlak MJ, Liu X, Locasale JW, Huang J, Roychoudhuri R, Finkel T, Klebanoff CA, Restifo NP (2019) T cell stemness and dysfunction in tumors are triggered by a common mechanism. Science 363(6434). https://doi.org/10.1126/science.aau0135

341. Eil R, Vodnala SK, Clever D, KlebanoffCA, Sukumar M, Pan JH, Palmer DC, Gros A, Yamamoto TN, Patel SJ, Guittard GC, Yu Z, Carbonaro V, Okkenhaug K, Schrump DS, Linehan WM, Roychoudhuri R, Restifo NP (2016) Ionic immune suppression within the tumour microenvironment limits $\mathrm{T}$ cell effector function. Nature 537(7621):539-543. https://doi.org/10.1038/ nature 19364

342. Husson MO, Ley D, Portal C, Gottrand M, Hueso T, Desseyn JL, Gottrand F (2016) Modulation of host defence against bacterial and viral infections by omega- 3 polyunsaturated fatty acids. J Inf Secur 73(6):523-535. https://doi.org/10.1016/j.jinf.2016.10.001

343. McFarland CT, Fan YY, Chapkin RS, Weeks BR, McMurray DN (2008) Dietary polyunsaturated fatty acids modulate resistance to mycobacterium tuberculosis in Guinea pigs. J Nutr 138(11):21232128. https://doi.org/10.3945/jn.108.093740

344. Paul KP, Leichsenring M, Pfisterer M, Mayatepek E, Wagner D, Domann M, Sonntag HG, Bremer HJ (1997) Influence of n-6 and n-3 polyunsaturated fatty acids on the resistance to experimental tuberculosis. Metabolism 46(6):619-624. https://doi.org/10.1016/ s0026-0495(97)90003-2

345. Jordao L, Lengeling A, Bordat Y, Boudou F, Gicquel B, Neyrolles O, Becker PD, Guzman CA, Griffiths G, Anes E (2008) Effects of omega-3 and -6 fatty acids on Mycobacterium tuberculosis in 
macrophages and in mice. Microbes Infect 10(12-13):1379-1386. https://doi.org/10.1016/j.micinf.2008.08.004

346. Grzybowski S, Dorken E (1983) Tuberculosis in Inuit. Ecol Dis 2(2):145-148

347. Kilabuk E, Momoli F, Mallick R, Van Dyk D, Pease C, Zwerling A, Potvin SE, Alvarez GG (2019) Social determinants of health among residential areas with a high tuberculosis incidence in a remote Inuit community. J Epidemiol Community Health 73(5): 401-406. https://doi.org/10.1136/jech-2018-211261

348. Patterson M, Flinn S, Barker K (2018) Addressing tuberculosis among Inuit in Canada. Can Commun Dis Rep 44(3-4):82-85. https://doi.org/10.14745/ccdr.v44i34a02

349. Soh AZ, Chee CB, Wang YT, Yuan JM, Koh WP (2016) Dietary cholesterol increases the risk whereas PUFAs reduce the risk of active tuberculosis in Singapore Chinese. J Nutr 146(5):10931100. https://doi.org/10.3945/jn.115.228049

350. Ralph AP, Waramori G, Pontororing GJ, Kenangalem E, Wiguna A, Tjitra E, Sandjaja LDB, Yeo TW, Chatfield MD, Soemanto RK, Bastian I, Lumb R, Maguire GP, Eisman J, Price RN, Morris PS, Kelly PM, Anstey NM (2013) L-Arginine and vitamin $\mathrm{D}$ adjunctive therapies in pulmonary tuberculosis: a randomised, double-blind, placebo-controlled trial. PLoS One 8(8):e70032. https://doi.org/10.1371/journal.pone.0070032

351. Schon T, Idh J, Westman A, Elias D, Abate E, Diro E, Moges F, Kassu A, Ayele B, Forslund T, Getachew A, Britton S, Stendahl O, Sundqvist T (2011) Effects of a food supplement rich in arginine in patients with smear positive pulmonary tuberculosis - a randomised trial. Tuberculosis 91(5):370-377. https://doi.org/10. 1016/j.tube.2011.06.002

352. Behr FM, Chuwonpad A, Stark R, van Gisbergen K (2018) Armed and ready: transcriptional regulation of tissue-resident memory CD8 T cells. Front Immunol 9:1770. https://doi.org/10.3389/ fimmu.2018.01770

353. Park SL, Gebhardt T, Mackay LK (2019) Tissue-resident memory $\mathrm{T}$ cells in cancer immunosurveillance. Trends Immunol 40(8): 735-747. https://doi.org/10.1016/j.it.2019.06.002

354. Li C, Zhu B, Son YM, Wang Z, Jiang L, Xiang M, Ye Z, Beckermann KE, Wu Y, Jenkins JW, Siska PJ, Vincent BG, Prakash YS, Peikert T, Edelson BT, Taneja R, Kaplan MH, Rathmell JC, Dong H, Hitosugi T, Sun J (2019) The transcription factor Bhlhe40 programs mitochondrial regulation of resident CD8(+) T cell fitness and functionality. Immunity 51(3):491507.e497. https://doi.org/10.1016/j.immuni.2019.08.013

355. Milner JJ, Toma C, Yu B, Zhang K, Omilusik K, Phan AT, Wang D, Getzler AJ, Nguyen T, Crotty S, Wang W, Pipkin ME, Goldrath AW (2017) Runx3 programs CD8(+) T cell residency in non-lymphoid tissues and tumours. Nature 552(7684):253-257. https://doi.org/10.1038/nature24993

356. Mehta MM, Weinberg SE, Chandel NS (2017) Mitochondrial control of immunity: beyond ATP. Nat Rev Immunol 17(10): 608-620. https://doi.org/10.1038/nri.2017.66

357. Philip M, Schietinger A (2019) Heterogeneity and fate choice: T cell exhaustion in cancer and chronic infections. Curr Opin Immunol 58:98-103. https://doi.org/10.1016/j.coi.2019.04.014

358. Balmer ML, Ma EH, Bantug GR, Grahlert J, Pfister S, Glatter T, Jauch A, Dimeloe S, Slack E, Dehio P, Krzyzaniak MA, King CG, Burgener AV, Fischer M, Develioglu L, Belle R, Recher M, Bonilla WV, Macpherson AJ, Hapfelmeier S, Jones RG, Hess C (2016) Memory CD8(+) T cells require increased concentrations of acetate induced by stress for optimal function. Immunity 44(6): 1312-1324. https://doi.org/10.1016/j.immuni.2016.03.016

359. Narita T, Weinert BT, Choudhary C (2019) Functions and mechanisms of non-histone protein acetylation. Nat Rev Mol Cell Biol 20(3):156-174. https://doi.org/10.1038/s41580-018-0081-3

360. Mashimo T, Pichumani K, Vemireddy V, Hatanpaa KJ, Singh DK, Sirasanagandla S, Nannepaga S, Piccirillo SG, Kovacs Z,
Foong C, Huang Z, Barnett S, Mickey BE, DeBerardinis RJ, Tu BP, Maher EA, Bachoo RM (2014) Acetate is a bioenergetic substrate for human glioblastoma and brain metastases. Cell 159(7): 1603-1614. https://doi.org/10.1016/j.cell.2014.11.025

361. Comerford SA, Huang Z, Du X, Wang Y, Cai L, Witkiewicz AK, Walters H, Tantawy MN, Fu A, Manning HC, Horton JD, Hammer RE, McKnight SL, Tu BP (2014) Acetate dependence of tumors. Cell 159(7):1591-1602. https://doi.org/10.1016/j.cell. 2014.11.020

362. Wiens KE, Ernst JD (2016) The mechanism for type I interferon induction by Mycobacterium tuberculosis is bacterial strain-dependent. PLoS Pathog 12(8):e1005809. https://doi.org/10.1371/ journal.ppat.1005809

363. McNab F, Mayer-Barber K, Sher A, Wack A, O'Garra A (2015) Type I interferons in infectious disease. Nat Rev Immunol 15(2): 87-103. https://doi.org/10.1038/nri3787

364. Berry MP, Graham CM, McNab FW, Xu Z, Bloch SA, Oni T, Wilkinson KA, Banchereau R, Skinner J, Wilkinson RJ, Quinn C, Blankenship D, Dhawan R, Cush JJ, Mejias A, Ramilo O, Kon OM, Pascual V, Banchereau J, Chaussabel D, O'Garra A (2010) An interferon-inducible neutrophil-driven blood transcriptional signature in human tuberculosis. Nature 466(7309):973-977. https://doi.org/10.1038/nature09247

365. Teles RM, Graeber TG, Krutzik SR, Montoya D, Schenk M, Lee DJ, Komisopoulou E, Kelly-Scumpia K, Chun R, Iyer SS, Sarno EN, Rea TH, Hewison M, Adams JS, Popper SJ, Relman DA, Stenger S, Bloom BR, Cheng G, Modlin RL (2013) Type I interferon suppresses type II interferon-triggered human antimycobacterial responses. Science 339(6126):1448-1453. https:// doi.org/10.1126/science. 1233665

366. Mayer-Barber KD, Andrade BB, Oland SD, Amaral EP, Barber DL, Gonzales J, Derrick SC, Shi R, Kumar NP, Wei W, Yuan X, Zhang G, Cai Y, Babu S, Catalfamo M, Salazar AM, Via LE, Barry CE 3rd, Sher A (2014) Host-directed therapy of tuberculosis based on interleukin-1 and type I interferon crosstalk. Nature 511(7507):99-103. https://doi.org/10.1038/nature13489

367. Wu J, Sun L, Chen X, Du F, Shi H, Chen C, Chen ZJ (2013) Cyclic GMP-AMP is an endogenous second messenger in innate immune signaling by cytosolic DNA. Science 339(6121):826830. https://doi.org/10.1126/science.1229963

368. West AP, Shadel GS, Ghosh S (2011) Mitochondria in innate immune responses. Nat Rev Immunol 11(6):389-402. https:// doi.org/10.1038/nri2975

369. Murphy MP (2009) How mitochondria produce reactive oxygen species. Biochem J 417(1):1-13. https://doi.org/10.1042/ BJ20081386

370. Weinberg SE, Sena LA, Chandel NS (2015) Mitochondria in the regulation of innate and adaptive immunity. Immunity 42(3):406417. https://doi.org/10.1016/j.immuni.2015.02.002

371. Cumming BM, Addicott KW, Adamson JH, Steyn AJ (2018) Mycobacterium tuberculosis induces decelerated bioenergetic metabolism in human macrophages. Elife:7. https://doi.org/10.7554/ eLife.39169

372. Tully G, Kortsik C, Hohn H, Zehbe I, Hitzler WE, Neukirch C, Freitag K, Kayser K, Maeurer MJ (2005) Highly focused T cell responses in latent human pulmonary Mycobacterium tuberculosis infection. J Immunol 174(4):2174-2184. https://doi.org/10.4049/ jimmunol.174.4.2174

373. Wong EA, Joslyn L, Grant NL, Klein E, Lin PL, Kirschner DE, Flynn JL (2018) Low levels of T cell exhaustion in tuberculous lung granulomas. Infect Immun 86(9). https://doi.org/10.1128/ IAI.00426-18

374. Yuneva M, Zamboni N, Oefner P, Sachidanandam R, Lazebnik Y (2007) Deficiency in glutamine but not glucose induces MYCdependent apoptosis in human cells. J Cell Biol 178(1):93-105. https://doi.org/10.1083/jcb.200703099 
375. Perez-Escuredo J, Dadhich RK, Dhup S, Cacace A, Van Hee VF, De Saedeleer CJ, Sboarina M, Rodriguez F, Fontenille MJ, Brisson L, Porporato PE, Sonveaux P (2016) Lactate promotes glutamine uptake and metabolism in oxidative cancer cells. Cell Cycle 15(1):72-83. https://doi.org/10.1080/15384101.2015. 1120930

376. Gao P, Tchernyshyov I, Chang TC, Lee YS, Kita K, Ochi T, Zeller KI, De Marzo AM, Van Eyk JE, Mendell JT, Dang CV (2009) cMyc suppression of miR-23a/b enhances mitochondrial glutaminase expression and glutamine metabolism. Nature 458(7239):762765. https://doi.org/10.1038/nature07823

377. Yang C, Sudderth J, Dang T, Bachoo RM, McDonald JG, DeBerardinis RJ (2009) Glioblastoma cells require glutamate dehydrogenase to survive impairments of glucose metabolism or Akt signaling. Cancer Res 69(20):7986-7993. https://doi.org/10. 1158/0008-5472.Can-09-2266

378. Metallo CM, Gameiro PA, Bell EL, Mattaini KR, Yang J, Hiller K, Jewell CM, Johnson ZR, Irvine DJ, Guarente L, Kelleher JK, Vander Heiden MG, Iliopoulos O, Stephanopoulos G (2011) Reductive glutamine metabolism by IDH1 mediates lipogenesis under hypoxia. Nature 481(7381):380-384. https://doi.org/10. 1038/nature10602

379. Wang YP, Zhou W, Wang J, Huang X, Zuo Y, Wang TS, Gao X, Xu YY, Zou SW, Liu YB, Cheng JK, Lei QY (2016) Arginine methylation of MDH1 by CARM1 inhibits glutamine metabolism and suppresses pancreatic cancer. Mol Cell 64(4):673-687. https://doi.org/10.1016/j.molcel.2016.09.028

380. Koppula P, Zhang Y, Zhuang L, Gan B (2018) Amino acid transporter SLC7A11/xCT at the crossroads of regulating redox homeostasis and nutrient dependency of cancer. Cancer Commun 38(1):12. https://doi.org/10.1186/s40880-018-0288-x

381. Goto M, Miwa H, Shikami M, Tsunekawa-Imai N, Suganuma K, Mizuno S, Takahashi M, Mizutani M, Hanamura I, Nitta M (2014) Importance of glutamine metabolism in leukemia cells by energy production through TCA cycle and by redox homeostasis. Cancer Investig 32(6):241-247. https://doi.org/10.3109/07357907.2014. 907419

382. Sugimoto K, Suzuki HI, Fujimura T, Ono A, Kaga N, Isobe Y, Sasaki M, Taka H, Miyazono K, Komatsu N (2015) A clinically attainable dose of L-asparaginase targets glutamine addiction in lymphoid cell lines. Cancer Sci 106(11):1534-1543. https://doi. org/10.1111/cas. 12807

383. Krall AS, Xu S, Graeber TG, Braas D, Christofk HR (2016) Asparagine promotes cancer cell proliferation through use as an amino acid exchange factor. Nat Commun 7:11457. https://doi. org/10.1038/ncomms11457

384. Sheen JH, Zoncu R, Kim D, Sabatini DM (2011) Defective regulation of autophagy upon leucine deprivation reveals a targetable liability of human melanoma cells in vitro and in vivo. Cancer Cell 19(5):613-628. https://doi.org/10.1016/j.ccr.2011.03.012

385. Scott L, Lamb J, Smith S, Wheatley DN (2000) Single amino acid (arginine) deprivation: rapid and selective death of cultured transformed and malignant cells. Br J Cancer 83(6):800-810. https:// doi.org/10.1054/bjoc.2000.1353

386. Wang Z, Yip LY, Lee JHJ, Wu Z, Chew HY, Chong PKW, Teo CC, Ang HY, Peh KLE, Yuan J, Ma S, Choo LSK, Basri N, Jiang X, Yu Q, Hillmer AM, Lim WT, Lim TKH, Takano A, Tan EH, Tan DSW, Ho YS, Lim B, Tam WL (2019) Methionine is a metabolic dependency of tumor-initiating cells. Nat Med 25(5):825837. https://doi.org/10.1038/s41591-019-0423-5

387. Geck RC, Toker A (2016) Nonessential amino acid metabolism in breast cancer. Adv Biol Regul 62:11-17. https://doi.org/10.1016/j. jbior.2016.01.001

388. Locasale JW (2013) Serine, glycine and one-carbon units: cancer metabolism in full circle. Nat Rev Cancer 13(8):572-583. https:// doi.org/10.1038/nrc3557
389. Chaneton B, Hillmann P, Zheng L, Martin ACL, Maddocks ODK, Chokkathukalam A, Coyle JE, Jankevics A, Holding FP, Vousden KH, Frezza C, O'Reilly M, Gottlieb E (2012) Serine is a natural ligand and allosteric activator of pyruvate kinase M2. Nature 491(7424):458-462. https://doi.org/10.1038/nature11540

390. Keenan MM, Chi JT (2015) Alternative fuels for cancer cells. Cancer J 21(2):49-55. https://doi.org/10.1097/ppo. 0000000000000104

391. Schug ZT, Vande Voorde J, Gottlieb E (2016) The metabolic fate of acetate in cancer. Nat Rev Cancer 16(11):708-717. https://doi. org/10.1038/nrc.2016.87

392. Yoshii Y, Furukawa T, Saga T, Fujibayashi Y (2015) Acetate/ acetyl-CoA metabolism associated with cancer fatty acid synthesis: overview and application. Cancer Lett 356(2 Pt A):211-216. https://doi.org/10.1016/j.canlet.2014.02.019

393. Fallarino F, Grohmann U, You S, McGrath BC, Cavener DR, Vacca C, Orabona C, Bianchi R, Belladonna ML, Volpi C, Santamaria P, Fioretti MC, Puccetti P (2006) The combined effects of tryptophan starvation and tryptophan catabolites downregulate $\mathrm{T}$ cell receptor zeta-chain and induce a regulatory phenotype in naive T cells. J Immunol 176(11):6752-6761. https://doi. org/10.4049/jimmunol.176.11.6752

394. Fallarino F, Grohmann U, You S, McGrath BC, Cavener DR, Vacca C, Orabona C, Bianchi R, Belladonna ML, Volpi C, Fioretti MC, Puccetti P (2006) Tryptophan catabolism generates autoimmune-preventive regulatory $\mathrm{T}$ cells. Transpl Immunol 17(1):58-60. https://doi.org/10.1016/j.trim.2006.09.017

395. Munn DH, Sharma MD, Baban B, Harding HP, Zhang Y, Ron D, Mellor AL (2005) GCN2 kinase in T cells mediates proliferative arrest and anergy induction in response to indoleamine 2,3dioxygenase. Immunity 22(5):633-642. https://doi.org/10.1016/j. immuni.2005.03.013

396. Duffy AG, Melillo G, Turkbey B, Allen D, Choyke PL, Chen C, Raffeld M, Doroshow JH, Murgo A, Kummar S (2010) A pilot trial of oral topotecan (TPT) in patients with refractory advanced solid neoplasms expressing HIF-1 $\alpha$. J Clin Oncol 28(15 suppl): e13518-e13518. https://doi.org/10.1200/jco.2010.28.15_suppl. e13518

397. Schilling B, Sucker A, Griewank K, Zhao F, Weide B, Gorgens A, Giebel B, Schadendorf D, Paschen A (2013) Vemurafenib reverses immunosuppression by myeloid derived suppressor cells. Int J Cancer 133(7):1653-1663. https://doi.org/10.1002/ijc.28168

398. Beijer MR, Kraal G, den Haan JM (2014) Vitamin A and dendritic cell differentiation. Immunology 142(1):39-45. https://doi.org/10. 1111/imm. 12228

399. Cassani B, Villablanca EJ, De Calisto J, Wang S, Mora JR (2012) Vitamin A and immune regulation: role of retinoic acid in gutassociated dendritic cell education, immune protection and tolerance. Mol Asp Med 33(1):63-76. https://doi.org/10.1016/j.mam. 2011.11.001

400. Ida S, Hiki N, Cho H, Sakamaki K, Ito S, Fujitani K, Takiguchi N, Kawashima Y, Nishikawa K, Sasako M, Aoyama T, Honda M, Sato T, Nunobe S, Yoshikawa T (2017) Randomized clinical trial comparing standard diet with perioperative oral immunonutrition in total gastrectomy for gastric cancer. Br J Surg 104(4):377-383. https://doi.org/10.1002/bjs.10417

401. Miyata H, Yano M, Yasuda T, Yamasaki M, Murakami K, Makino T, Nishiki K, Sugimura K, Motoori M, Shiraishi O, Mori M, Doki Y (2017) Randomized study of the clinical effects of omega-3 fatty acid-containing enteral nutrition support during neoadjuvant chemotherapy on chemotherapy-related toxicity in patients with esophageal cancer. Nutrition 33:204-210. https:// doi.org/10.1016/j.nut.2016.07.004

402. Sorensen LS, Thorlacius-Ussing O, Rasmussen HH, LundbyeChristensen S, Calder PC, Lindorff-Larsen K, Schmidt EB (2014) Effects of perioperative supplementation with omega-3 
fatty acids on leukotriene $\mathrm{B}(4)$ and leukotriene $\mathrm{B}(5)$ production by stimulated neutrophils in patients with colorectal cancer: a randomized, placebo-controlled intervention trial. Nutrients 6(10): 4043-4057. https://doi.org/10.3390/nu6104043

403. Mocellin MC, Pastore e Silva Jde A, Camargo Cde Q, Fabre ME, Gevaerd S, Naliwaiko K, Moreno YM, Nunes EA, Trindade EB (2013) Fish oil decreases C-reactive protein/albumin ratio improving nutritional prognosis and plasma fatty acid profile in colorectal cancer patients. Lipids 48(9):879-888. https://doi.org/10.1007/ s11745-013-3816-0

404. Silva Jde A, Trindade EB, Fabre ME, Menegotto VM, Gevaerd S, Buss Zda S, Frode TS (2012) Fish oil supplement alters markers of inflammatory and nutritional status in colorectal cancer patients. Nutr Cancer 64(2):267-273. https://doi.org/10.1080/01635581. 2012.643133

405. Bonatto SJ, Oliveira HH, Nunes EA, Pequito D, Iagher F, Coelho I, Naliwaiko K, Kryczyk M, Brito GA, Repka J, Saboia LV, Fukujima G, Calder PC, Fernandes LC (2012) Fish oil supplementation improves neutrophil function during cancer chemotherapy. Lipids 47(4):383-389. https://doi.org/10.1007/s11745-011-36430

406. Trabal J, Leyes P, Forga M, Maurel J (2010) Potential usefulness of an EPA-enriched nutritional supplement on chemotherapy tolerability in cancer patients without overt malnutrition. Nutr Hosp 25(5):736-740

407. Rotovnik Kozjek N, Kompan L, Soeters P, Oblak I, Mlakar Mastnak D, Mozina B, Zadnik V, Anderluh F, Velenik V
(2011) Oral glutamine supplementation during preoperative radiochemotherapy in patients with rectal cancer: a randomised double blinded, placebo controlled pilot study. Clin Nutr 30(5):567-570. https://doi.org/10.1016/j.clnu.2011.06.003

408. Seguin P, Locher C, Boudjema K, Hamon C, Mouchel C, Malledant Y, Bellissant E (2016) Effect of a perioperative nutritional supplementation with oral impact $(\mathrm{R})$ in patients undergoing hepatic surgery for liver cancer: a prospective, placebo-controlled, randomized, double-blind study. Nutr Cancer 68(3):464-472. https://doi.org/10.1080/01635581.2016.1153670

409. Marano L, Porfidia R, Pezzella M, Grassia M, Petrillo M, Esposito G, Braccio B, Gallo P, Boccardi V, Cosenza A, Izzo G, Di Martino N (2013) Clinical and immunological impact of early postoperative enteral immunonutrition after total gastrectomy in gastric cancer patients: a prospective randomized study. Ann Surg Oncol 20(12):3912-3918. https://doi.org/10.1245/s10434-013-3088-1

410. Okamoto Y, Okano K, Izuishi K, Usuki H, Wakabayashi H, Suzuki Y (2009) Attenuation of the systemic inflammatory response and infectious complications after gastrectomy with preoperative oral arginine and omega-3 fatty acids supplemented immunonutrition. World J Surg 33(9):1815-1821. https://doi. org/10.1007/s00268-009-0140-1

Publisher's note Springer Nature remains neutral with regard to jurisdictional claims in published maps and institutional affiliations. 